\title{
EXTRATOS VEGETAIS COMO PROMOTORES DO CRESCIMENTO DE LEITÕES RECÉM-DESMAMADOS
}

\author{
LILIANA LOTUFO OETTING
}

Tese apresentada à Escola Superior de Agricultura "Luiz de Queiroz", Universidade de São Paulo, para obtenção do título de Doutor em Agronomia, Área de Concentração: Ciência Animal e Pastagens.

PIR A C I C A B A

Estado de São Paulo - Brasil

Julho - 2005 


\title{
EXTRATOS VEGETAIS COMO PROMOTORES DO CRESCIMENTO DE LEITÕES RECÉM-DESMAMADOS
}

\author{
LILIANA LOTUFO OETTING \\ Zootecnista \\ Orientador: Prof. Dr. VALDOMIRO SHIGUERU MIYADA \\ Tese apresentada à Escola Superior de \\ Agricultura "Luiz de Queiroz", Universidade de \\ São Paulo, para obtenção do título de Doutor em \\ Agronomia, Área de Concentração: Ciência \\ Animal e Pastagens.
}

PIR A C I C A B A

Estado de São Paulo - Brasil

Julho - 2005 
Dados Internacionais de Catalogação na Publicação (CIP) DIVISÃO DE BIBLIOTECA E DOCUMENTAÇÃO - ESALQ/USP

Oetting, Liliana Lotufo

Extratos vegetais como promotores do crescimento de leitões recém-desmamados / Liliana Lotufo Oetting. - - Piracicaba, 2005.

$66 \mathrm{p}$.

Tese (Doutorado) - - Escola Superior de Agricultura Luiz de Queiroz, 2005. Bibliografia.

1. Aditivos alimentares para animais 2. Crescimento animal 3. Desmama animal 4. Digestabilidade 5. Extrato vegetal 6. Leitões 7. Microbiologia veterinária I. Título

CDD 636.4 
Aos meus pais,

Afonso e Lúcia

Aos meus irmãos e cunhadas,

Luís Afonso e Daniela, Luciano e Luciane

Aos meus sogros e cunhado,

Seiji, Solange e Luís Gustavo

À sempre querida amiga,

Jacinta

Por todo apoio, carinho, incentivo e compreensão nessa fase da minha vida.

Com muito amor e gratidão,

DEDICO

Ao meu marido,

$$
\text { Carlos }
$$

Pelo amor, dedicação, companheirismo e valioso apoio em todos momentos que passamos juntos.

Ao meu filho,

Eduardo

Porfazer parte de um momento tão especial da minha vida.

Com muito amor,

OFEREÇO 


\section{AGRADECIMENTOS}

A Deus;

À FAPESP, pela bolsa concedida durante o curso e financiamento do projeto de pesquisa;

Ao Prof. Dr. Valdomiro S. Miyada, pela confiança, amizade e ensinamentos como orientador;

Ao Prof. Dr. José F. M. Menten, por discutir e acompanhar o andamento do projeto;

Ao Dr. Gustavo J. M. M. de Lima, pela amizade e fundamental apoio no planejamento do projeto e análise dos dados com conselhos e sugestões;

Ao Prof. Dr. Paulo Chanel, pela orientação na área de farmacognósia, esclarecendo dúvidas e auxiliando na metodologia e obtenção dos extratos vegetais;

Aos Professores do Departamento de Zootecnia, pelo convívio e amizade durante o curso;

Ao Prof. Dr. Irineu U. Packer, pelas sugestões na análise estatística;

À Profa. Dra. Catarina A. Gomide, pela amizade e pelo apoio nas análises bromatológicas;

À Profa. Dra. Maria Inês Ré, pelas sugestões na área de microencapsulamento dos óleos essenciais;

Ao Prof. Dr. Elliot W. Kitajima, pela contribuição na área de microscopia eletrônica;

À colega Fernanda M. Tucci, pelas dicas e conselhos a respeito de análises enzimáticas;

Ao Prof. João Negrão, pela colaboração na realização de análises laboratoriais;

Ao funcionário Nilton dos Santos, pela contribuição na análise histológica;

Aos estagiários e amigos, Pedro A. Giani e Urbano dos S. Ruiz, pela amizade e inestimável colaboração na condução dos experimentos;

Aos funcionários do Setor de Suinocultura, Srs. Pires, Leonilço, Galvão e Adão pela ajuda nos experimentos;

Ao funcionário Antonio Carlos, pelo auxílio na confecção das dietas experimentais;

Aos demais funcionários do Departamento de Zootecnia, Vera, Henrique, Claudia, Augusto, Ednézio, pela ajuda durante todo o curso; 
À empresa Givaudan do Brasil Ltda., pelo fornecimento de óleos essenciais microencapsulados;

Às empresas MCassab Com. e Ind. Ltda, Nutron Alimentos Ltda., Ajinomoto Biolatina Ind. e Com. Ltda, Sloten do Brasil Ind. e Com. Ltda, Supre Mais Ind. e Com. Ltda, pela doação de ingredientes para a produção das dietas experimentais;

Aos amigos, Adriana Pedroso, Aline, Andrea José, Flávio, Adriana Figueiredo, José Otávio, Juliana, pelo apoio e amizade durante todo o curso;

Aos demais companheiros de Departamento, Leandro, Itiberê, Juliano, Luiz, pelos ótimos momentos de convivência;

Àqueles que de alguma maneira, direta ou indiretamente, contribuíram para a realização deste trabalho, a minha enorme gratidão. 


\section{SUMÁRIO}

Página

LISTA DE FIGURAS................................................................................. viii

LISTA DE TABELAS................................................................................. ix

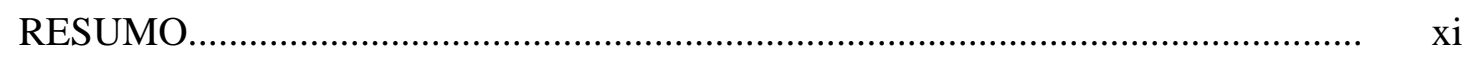

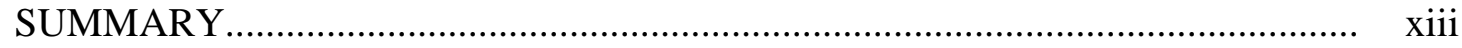

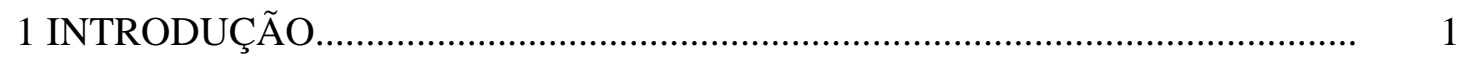

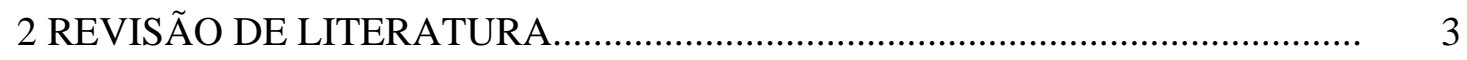

$2.1 \quad$ Fisiologia digestiva de leitões recém-desmamados......................................... 3

$2.2 \quad$ Promotores do crescimento........................................................................ 4

2.2.1 Modos de ação dos promotores do crescimento.......................................... 5

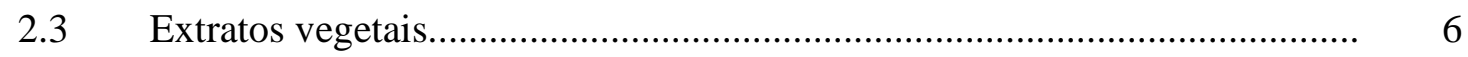

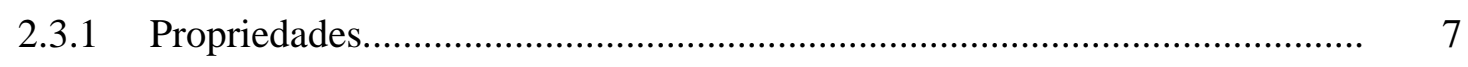

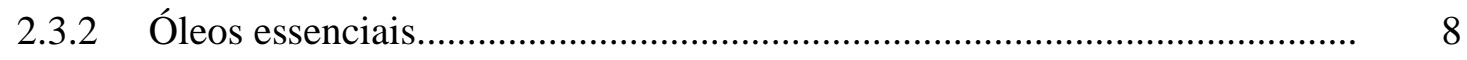

2.3.3 Modos de ação........................................................................................... 9

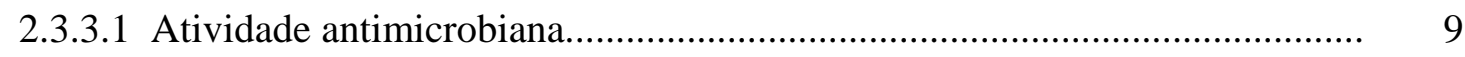

2.3.3.2 Atividade antioxidante........................................................................ 11

2.3.3.3 Estímulo da atividade enzimática............................................................ 12

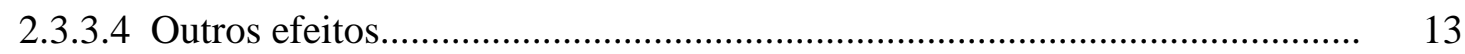

3 MATERIAL E MÉTODOS.......................................................................... 15

3.1 Instalações experimentais e animais............................................................ 15

3.2 Escolha e preparo dos extratos vegetais.................................................... 16

3.3 Teste de consumo..................................................................................... 17 
3.4 Tratamentos e dietas basais....................................................................... 17

3.5 Experimento I............................................................................. 20

3.5.1 Digestibilidade aparente dos nutrientes........................................................ 20

3.5.2 Morfometria dos órgãos....................................................................... 21

3.5.3 Histologia do epitélio intestinal.................................................................. 21

3.5.3.1 Microscopia óptica................................................................................. 21

3.5.3.2 Microscopia eletrônica de varredura................................................................ 22

3.5.4 Microbiologia intestinal......................................................................... 22

3.6 Experimentos II e III........................................................................... 23

3.6.1 Desempenho.......................................................................................... 23

3.6.2 Frequência de diarréia................................................................................. 23

3.7 Delineamento experimental................................................................. 24

3.8 Análise dos dados....................................................................................... 24

4 RESULTADOS E DISCUSSÃO........................................................................ 25

4.1 Digestibilidade aparente dos nutrientes........................................................... 25

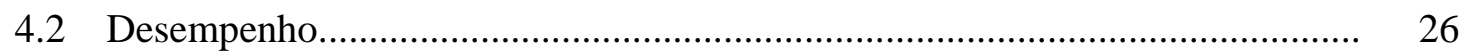

4.3 Morfometria dos órgãos............................................................................. $\quad 30$

4.4 Histologia do epitélio intestinal...................................................................... 32

4.5 Microbiologia intestinal........................................................................ 37

4.6 Frequência de diarréia.......................................................................................... 39

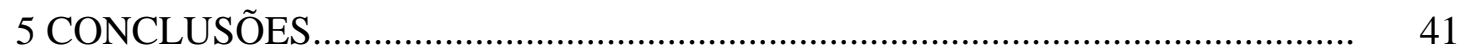

REFERÊNCIAS BIBLIOGRÁFICAS................................................................ 42

APÊNDICES 


\section{LISTA DE FIGURAS}

Página

1 Imagens das vilosidades do duodeno, jejuno e íleo feitas por

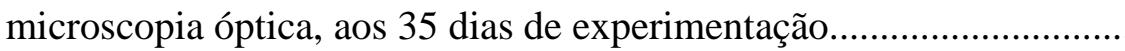

2 Eletronmicrografias de varredura das vilosidades do duodeno dos leitões aos 35 dias de experimentação, de acordo com os tratamentos..

3 Eletronmicrografias de varredura das vilosidades do jejuno dos leitões aos 35 dias de experimentação, de acordo com os tratamentos...............

4 Eletronmicrografias de varredura das vilosidades do íleo dos leitões aos 35 dias de experimentação, de acordo com os tratamentos. 


\section{LISTA DE TABELAS}

Página

1 Composição do extrato vegetal encapsulado utilizado nos

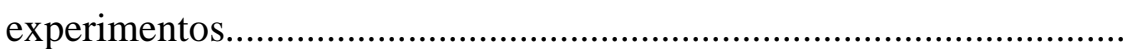

2 Média de consumo diário de ração (kg/dia) de leitões recebendo dieta controle e com diferentes concentrações de extratos vegetais encapsulados

3 Composição percentual e valores calculados das dietas basais

4 Médias dos coeficientes de digestibilidade aparente para matéria seca e energia bruta, em função dos tratamentos.

5 Médias de peso vivo aos 14 dias (P14, kg), consumo diário de ração (CDR, kg/dia), ganho diário de peso (GDP, kg/dia) e conversão alimentar (CA) para o período de 1 a 14 dias de experimentação...........

6 Médias de peso vivo aos 35 dias pós-desmame (P35, kg), consumo diário de ração (CDR, kg/dia), ganho diário de peso (GDP, kg/dia) e conversão alimentar (CA) para o período de 1 a 35 dias de experimentação

7 Valores de $\mathrm{P}$ obtidos nos testes estatísticos da análise multivariada...... 
8 Médias dos pesos relativos (porcentagem do peso vivo) dos órgãos digestórios e não digestórios, assim como do comprimento, do comprimento relativo e da relação peso:comprimento do intestino delgado, em função dos tratamentos.......................................................

9 Médias de altura das vilosidades $(\mathrm{AV}, \mu \mathrm{m})$, profundidade de criptas (PC, $\mu \mathrm{m})$ e relação altura das vilosidades/profundidade de criptas (AV/PC) do duodeno, jejuno e íleo, em função dos tratamentos.............

10 Médias das contagens de microrganismos (log UFC/g de conteúdo do intestino delgado) de leitões, em função dos tratamentos

11 Médias de frequência de diarréia (MFD, \%) e média transformada (MT) para os períodos de 1 a 14 e 1 a 35 dias de experimentação......... 


\title{
EXTRATOS VEGETAIS COMO PROMOTORES DO CRESCIMENTO DE LEITÕES RECÉM-DESMAMADOS
}

\author{
Autor: LILIANA LOTUFO OETTING \\ Orientador: Prof. Dr. VALDOMIRO SHIGUERU MIYADA
}

\section{RESUMO}

Apesar da comprovada capacidade de melhorar o desempenho de suínos, o uso de antimicrobianos como promotores do crescimento vem sendo progressivamente restringido em diversos países. As novas regulamentações têm forçado a procura por alternativas ao uso de antibióticos e quimioterápicos como promotores do crescimento de suínos. Os extratos vegetais constituem uma dessas alternativas pesquisadas. Sendo assim, o objetivo do trabalho foi avaliar os efeitos de antimicrobianos e extratos vegetais sobre a digestibilidade aparente dos nutrientes, desempenho, morfometria dos órgãos, histologia do epitélio intestinal, microbiologia intestinal e frequência de diarréia de leitões recém-desmamados. Foram realizados três experimentos em blocos casualizados, nos quais foram testados, durante 35 dias, cinco tratamentos: controle - ração basal; antimicrobiano - basal com bacitracina de zinco, olaquindox e colistina (50 ppm de cada); extrato vegetal A, B e C - basal com 700, 1200 e 2100 ppm de extrato vegetal, respectivamente. O extrato vegetal foi constituído de quantidades iguais de óleo essencial de cravo, tomilho, orégano, eugenol e carvacrol. Foram utilizados 40 leitões em cada experimento, com idades iniciais e finais de, respectivamente, 21 e 56 dias. 
Foram alocados dois leitões (um macho castrado e uma fêmea) em cada baia (unidade experimental). No ensaio de digestibilidade (Experimento I) utilizou-se o método da coleta parcial de fezes, tendo o óxido crômico $\left(\mathrm{Cr}_{2} \mathrm{O}_{3}\right)$ como marcador. Ao final do Experimento I, um animal de cada unidade experimental foi abatido para análise de morfometria dos órgãos e coleta de amostras do epitélio intestinal para análise histológica e microbiológica. Nos Experimentos I, II e III, foram medidas a frequência de diarréia e as variáveis de desempenho. A digestibilidade da matéria seca foi maior $(\mathrm{P}<0,05)$ para o tratamento com extratos vegetais em relação ao tratamento controle e com antimicrobianos. Durante os períodos de 1 a 14 e 1 a 35 dias de experimentação, o tratamento antimicrobiano apresentou melhores resultados $(\mathrm{P}<0,05)$ de peso vivo, consumo diário de ração e ganho diário de peso que os demais tratamentos. Dentre os níveis de extratos vegetais, o maior nível de inclusão foi o que proporcionou melhores resultados de desempenho. $\mathrm{Na}$ análise de morfometria dos órgãos, foram encontradas diferenças $(\mathrm{P}<0,05)$ entre os tratamentos apenas para o peso relativo do trato gastrintestinal total e do intestino delgado vazio, sendo que os melhores (menores) resultados foram obtidos para os animais suplementados com antimicrobianos. Para a histologia do epitélio intestinal, novamente os melhores resultados foram obtidos para o tratamento com antimicrobianos, tendo apresentado maior altura de vilosidade $(\mathrm{P}<0,05)$ e menor relação altura de vilosidade e profundidade de cripta do íleo que os tratamentos com extratos vegetais. Não foram encontradas diferenças significativas $(P>0,05)$ para os resultados de microbiologia intestinal. A frequência de diarréia dos animais que receberam antimicrobianos foi inferior $(\mathrm{P}<0,05)$ àquela do tratamento controle ou extratos vegetais no período de 1 a 35 dias de experimentação, indicando eficácia dos antimicrobianos em controlar a diarréia. Os extratos vegetais apresentaram resultados intermediários entre o tratamento controle e com antimicrobianos para essa variável. 


\title{
HERBAL EXTRACTS AS GROWTH PROMOTERS OF WEANLING PIGS
}

\author{
Author: LILIANA LOTUFO OETTING \\ Adviser: Prof. Dr. VALDOMIRO SHIGUERU MIYADA
}

\section{SUMMARY}

The use of antimicrobials as growth promoters of swine has been gradually restricted in many countries. The new regulations have forced the search for alternatives to the antibiotic use as growth promoters for swine. The herbal extracts are one of these alternatives. The purpose of this work was to evaluate the antimicrobial agents and herbal extracts as growth promoters, based on intestinal morphology, histology, microbiology, digestibility, fecal score, and on performance of weanling pigs. Three randomized complete block design experiments were carried out to compare five treatments: control - basal diet; antimicrobial - basal diet plus Zn bacitracin, olaquindox, and colistin (50 ppm of each); herbal extract A, B and C - basal diet plus 700 ppm, 1200 ppm and 2100 ppm of herbal extract, respectively. The herbal extract consisted of a mixture of equal amounts of essential oils of thyme, clove, oregano, eugenol and carvacrol. In each Experiment, forty 21-d-weaned pigs were allotted to 20 suspended pens, with two pigs (a castrated male and a female) per pen (experimental unit) and four replications per treatment. Digestibility assay (Experiment I) was conducted using chromic oxide $\left(\mathrm{Cr}_{2} \mathrm{O}_{3}\right)$ as fecal marker. On $35^{\text {th }}$ day of experimental period, an animal of 
each experimental unit was slaughtered for morphological analysis and samples of the intestine epithelium were collected for histological and microbiological analysis. Performance data and fecal score of pigs were collected from Experiments I, II and III. The herbal extracts increased $(\mathrm{P}<.05)$ the dry matter apparent digestibility of the diet compared to control and antimicrobial treatments. The antimicrobial agents improved $(\mathrm{P}<.05)$ body weight, feed intake and average daily gain of weanling pigs during 1 to 14 and 1 to 35 days of experimental period compared to control and herbal extract. Among all levels of herbal extract, higher levels showed better performance results. The antimicrobial treatment improved the relative weights of the intestinal tract and empty small intestine $(\mathrm{P}<.05)$ and improved ileum villus height and the ratio of ileum villus height:crypt depth of animals. There was no statistical difference $(\mathrm{P}>.05)$ in microbiological analysis. During 1 to 35 days of experimental period, incidence of diarrhoea of pigs fed antimicrobials was statisticaly lower $(\mathrm{P}<.05)$ than those fed control or herbal extract diet, suggesting the efficacy of antimicrobials in diarrhoea control. Pigs fed herbal extract showed intermediary results between antimicrobial and control diets for this variable. 


\section{INTRODUÇÃO}

Os aditivos antimicrobianos (antibióticos e quimioterápicos) têm sido utilizados desde a década de 50 e são os promotores do crescimento de uso mais generalizado na produção animal (Menten, 2001), representando uma ferramenta importante para proporcionar uma produtividade adequada a animais criados em condições cada vez mais intensivas. A melhora no desempenho dos animais é atribuída à ação desses aditivos sobre os microrganismos da microbiota intestinal, atuando no controle e combate de patógenos.

Apesar da comprovada capacidade de melhorar o desempenho de suínos, o uso de antimicrobianos como promotores do crescimento vem sendo progressivamente restringido em diversos países. Acredita-se que, na União Européia, a partir de 2006 será proibido o uso de qualquer tipo de antibiótico e quimioterápico como promotor do crescimento na produção animal (Brugalli, 2003). Esta proibição deve-se à possibilidade do desenvolvimento da resistência bacteriana cruzada em humanos e à exigência do mercado consumidor por produtos livres de resíduos de antibióticos (Silva, 2000). Essas novas regulamentações têm forçado a procura de promotores do crescimento alternativos que garantam máximo crescimento dos animais sem afetar a qualidade do produto final (Miltenberg, 2000). As principais alternativas que têm sido pesquisadas incluem os prebióticos, probióticos, enzimas, ácidos orgânicos e, mais recentemente, os extratos vegetais.

A utilização de extratos vegetais e plantas medicinais para humanos data de milhares de anos, sendo muito difundida no Egito Antigo, China, Índia e Grécia (Kamel, 2000). A eficiência da atividade biológica dos extratos vegetais depende da espécie utilizada, concentração do princípio ativo presente na planta, a fonte de origem (caule, folhas ou semente, por exemplo), método de obtenção e estabilidade dos componentes (Kamel, 2000; Brugalli, 2003). Na literatura, existem diversos trabalhos avaliando a atividade antimicrobiana, antioxidante, antifúngica e/ou antihelmíntica de diferentes extratos vegetais, em experimentos in vitro, contra diversos patógenos animais e de alimentos. Pesquisas têm demonstrado que alguns 
extratos vegetais possuem efeitos muito próximos, ou superiores, ao dos antibióticos disponíveis no mercado (Kamel, 2000). Dentre os possíveis mecanismos de ação dos extratos vegetais no organismo animal, podem-se citar alterações na microbiota intestinal, aumento na digestibilidade e absorção de nutrientes, melhora da resposta imune e modificações morfo-histológicas do trato gastrintestinal (Brugalli, 2003).

Apesar da comprovada ação in vitro de diversos extratos vegetais, existem poucas informações sobre o seu uso na produção de suínos em condições brasileiras. Além disso, os resultados encontrados na literatura são ainda inconsistentes e pouco conclusivos. Assim, este trabalho teve como objetivo estudar os efeitos de antimicrobianos e diferentes concentrações de extratos vegetais sobre os parâmetros referentes à digestibilidade aparente dos nutrientes, desempenho, morfometria dos órgãos, histologia do epitélio intestinal, microbiologia intestinal e frequência de diarréia de leitões recém-desmamados. 


\section{REVISÃO DE LITERATURA}

\subsection{Fisiologia digestiva de leitões recém-desmamados}

O conhecimento da fisiologia do aparelho digestório de suínos recémdesmamados é de grande importância, pois o estresse decorrente da desmama e as mudanças de dieta e ambiente aos quais os leitões são submetidos tornam essa fase da vida do animal um grande desafio aos nutricionistas.

O período pós-desmama é uma fase extremamente complexa na vida do leitão, trazendo vários desafios para a manutenção de sua homeostase, que podem variar em incidência, duração e severidade de acordo com as características de cada granja (Stokes et al., 2001). Esses desafios incluem: desafio imunológico, pela presença de potenciais patógenos (Salmonella, Rotavirus, etc.), fatores ambientais (mudança de instalações e temperatura ambiente), mudança de dieta de líquida para sólida, falta de apetite, estresse decorrente da separação da mãe e reagrupamento social, alteração do ambiente intestinal $(\mathrm{pH}$, microbiota, suprimento de nutrientes) e interrupção da ingestão do leite materno, responsável pela proteção imune e proteção não específica contra microrganismos patogênicos (Stokes et al., 2001). Durante esse período de transição, é observada uma redução no crescimento dos animais, normalmente associada a alterações histológicas e bioquímicas no intestino delgado, como atrofia das vilosidades e aumento da profundidade de criptas, acarretando em reduzida capacidade de digestão e absorção de nutrientes (McCracken et al., 1999). Além disso, leitões recémdesmamados e com até quatro semanas de idade possuem o trato digestório relativamente imaturo, o que leva a uma digestão ineficiente de carboidratos e proteínas. A ineficiência de digestão se deve, em parte, a quantidades insuficientes de enzimas secretadas ao longo do trato gastrintestinal e secreção limitada de ácido clorídrico pelas células parietais do estômago (Geary et al., 1999). Com o pH acima do nível ideal, a pepsina não é ativada e a digestibilidade das 
proteínas é muito reduzida, acarretando na passagem de substrato fermentável a outras porções do intestino delgado (Campabadal et al., 1995). A digestão incompleta de carboidratos e proteínas, além de alterar a osmolaridade do conteúdo intestinal, pode propiciar um meio rico em substratos para bactérias patogênicas, contribuindo para a ocorrência de diarréia pós-desmama.

Apesar de todas essas dificuldades, a simples presença do alimento no trato digestório irá estimular as funções digestivas intestinais, através da secreção de hormônios, desenvolvimento do sistema enzimático e estímulo à proliferação celular, até que se alcance a maturidade do sistema e o animal possa suprir suas exigências nutricionais (Kelly \& King, 2001). Entretanto, para auxiliar nesse processo, têm sido utilizados aditivos na ração que contribuem para a manutenção das condições adequadas do trato gastrintestinal durante essa fase da vida do animal, como é o caso dos antimicrobianos promotores do crescimento (Baynes \& Varley, 2001).

\subsection{Promotores do crescimento}

Promotores do crescimento são compostos sintéticos orgânicos, compostos químicos ou elementos inorgânicos simples, administrados em pequenas quantidades com a finalidade de melhorar a taxa de crescimento e/ou conversão alimentar (Lima, 1999).

Os aditivos antimicrobianos (antibióticos e quimioterápicos) são os promotores do crescimento de uso mais generalizado na produção animal (Menten, 2001), representando uma ferramenta importante para proporcionar uma produtividade adequada a animais criados em condições cada vez mais intensivas.

Os antibióticos são substâncias produzidas por fungos, leveduras ou bactérias, enquanto que os quimioterápicos são substâncias obtidas por síntese química, com ação semelhante aos antibióticos (Menten, 2001). Os antibióticos e quimioterápicos representam um grupo de compostos com estruturas químicas heterogêneas e propriedades físico-químicas diferentes, que têm como único ponto comum a capacidade antibacteriana (Jong et al., 1985), resultando na alteração seletiva da população microbiana do intestino animal e no estímulo do crescimento das bactérias benéficas (Zuanon et al., 1998; Lima, 1999). Além disso, pode haver dois tipos de ação direta dos antimicrobianos sobre as bactérias e/ou fungos sensíveis: a morte do agente (efeito bactericida) ou a parada do seu crescimento e reprodução (efeito bacteriostático). Esses efeitos podem ser por interferência na síntese da parede celular, alterações 
na permeabilidade da membrana citoplasmática, interferências na replicação cromossômica e na síntese protéica celular (Tavares, 1990; Mellor, 2000).

De maneira geral, os efeitos do uso desses aditivos podem ser agrupados em três categorias: efeito metabólico (melhoria do desempenho através de efeito direto sobre o metabolismo do animal), nutricional (alterações na população microbiana e redução da espessura da parede intestinal promove maior disponibilidade de nutrientes, principalmente por haver economia de energia e nutrientes para manutenção desses tecidos corporais) e controle de doenças (inibição de bactérias intestinais causadoras de doenças subclínicas, permitindo que os animais expressem ao máximo o seu potencial genético para crescimento e deposição de carne) (Lima, 1999).

\subsubsection{Modos de ação dos promotores do crescimento}

De acordo com a literatura, a inclusão de níveis subterapêuticos de antimicrobianos na dieta pode melhorar em 5\% a conversão alimentar e de 3 a $6 \%$ o ganho de peso dos animais, sendo que melhores respostas são observadas em animais mais jovens e em ambientes com maior contaminação (Baynes \& Varley, 2001). O efeito benéfico dos antimicrobianos sobre o desempenho dos animais pode estar associado com seus efeitos sobre o epitélio intestinal, e consequente economia de nutrientes, efeitos sobre a microbiota intestinal e efeitos sobre a histologia do epitélio intestinal e digestibilidade de nutrientes.

Relatos apontam os promotores do crescimento como agentes modificadores da espessura da parede intestinal devido à eliminação de bactérias danosas (Coates et al., 1955, Eisser \& Somer, 1966; Butolo, 1999; Spring et al., 2001). Com a redução do número de microrganismos produtores de toxinas aderidos ao epitélio, haverá menor irritação da mucosa e, consequentemente, redução da espessura e massa da parede intestinal (Anderson et al., 1999), resultando em uma economia de nutrientes para manutenção dos tecidos (Henry et al., 1987; Lima, 1999). Também, pode ocorrer maior aproveitamento do alimento, decorrente da maior vascularização sanguínea do epitélio intestinal (Freitas, 1992). Entretanto, nem sempre os trabalhos apresentam resultados consistentes (Loddi et al., 2000).

A microbiota intestinal é composta por inúmeras espécies bacterianas, formando um sistema complexo e dinâmico, responsável por influenciar decisivamente fatores microbiológicos, imunológicos, fisiológicos, nutricionais e bioquímicos no hospedeiro (Tannock 
et al., 1998). A estabilidade da composição da flora normal do trato serve de linha mestra para o estudo dos efeitos externos sobre o sistema gastrintestinal (Madeira, 1999).

O uso de promotores do crescimento pode promover alterações na composição da microbiota em decorrência da perda da eficiência de fixação de certos microrganismos ao epitélio intestinal (Krause et al., 1997), alteração no perfil e na quantidade de substâncias produzidas no lúmen intestinal (Jin et al., 1997), alterações nos níveis de ácidos graxos voláteis produzidos (Brugalli, 2003) e controle de bactérias causadoras de doenças não diagnosticáveis que deprimem o crescimento do animal (Menten, 1995). Também, contribui na redução da produção de amônia e de outros metabólitos tóxicos (aminas e endotoxinas) pela microbiota (Jin et al., 1997), protegendo o epitélio intestinal (Butolo, 1999). Uma outra evidência de que os antibióticos promotores do crescimento atuam sobre a microbiota intestinal é o fato deles não exercerem efeitos benéficos em animais "germ-free", comprovando a teoria de que seu efeito esteja mais associado com a atividade antimicrobiana do que por ação direta na fisiologia do animal (Muramatsu et al., 1994).

Os promotores de crescimento, também, podem exercer uma influência significativa sobre a digestibilidade dos nutrientes, pois eles interferem na secreção de enzimas e sucos gastrintestinais (Butolo, 1999; Miltenberg, 2000; Strickling et al., 2000; Brugalli, 2003) e podem promover alterações positivas sobre a histologia do epitelial intestinal, como o aumento da altura das vilosidades e redução da profundidade das criptas (Butolo, 1999).

Apesar de várias hipóteses terem sido propostas até hoje, não há um consenso sobre o exato modo de ação dos antimicrobianos no organismo animal (Menten, 2001).

\subsection{Extratos Vegetais}

A utilização de extratos vegetais e plantas medicinais para humanos data de milhares de anos, sendo muito difundida no Egito Antigo, China, Índia e Grécia (Kamel, 2000). Muitos extratos vegetais naturais têm fornecido a base para modernos medicamentos, tais como a digoxina da planta digitalis e a efedrina da planta chinesa "na huang” (Brugalli, 2003).

Os efeitos benéficos das plantas estão associados com a constituição de seus princípios ativos e compostos secundários. Levando em consideração a enorme variedade de plantas existentes, constituídas por inúmeras substâncias, o grande desafio na utilização de extratos vegetais, como alternativa ao uso de antimicrobianos, está na identificação e avaliação dos efeitos exercidos pelos diferentes componentes presentes nos óleos essenciais sobre o 
organismo animal (Kamel, 2000). Esta é uma busca que está apenas começando, principalmente se levar em conta que os antibióticos e quimioterápicos passaram por décadas de desenvolvimento e testes antes de serem aprovados e utilizados como promotores do crescimento na produção animal.

\subsubsection{Propriedades}

Os efeitos exercidos pelas plantas podem ser explicados pela presença e constituição de seu(s) princípio(s) ativo(s). Princípios ativos são componentes químicos, presentes em todas as partes das plantas ou em partes específicas, que conferem às plantas medicinais alguma atividade terapêutica (Martins et al., 2000).

Os princípios ativos dos vegetais são moléculas de baixo peso molecular oriundas do metabolismo secundário dos vegetais. Estes compostos são produzidos como um mecanismo de defesa da planta contra fatores externos, tais como estresse fisiológico (falta de água ou nutriente, por exemplo), fatores ambientais (variações climáticas) e proteção contra predadores e patógenos. É por esse motivo que a composição dos constituintes metabólicos de uma planta pode variar de acordo com o tipo de planta, local de origem e condições climáticas durante seu desenvolvimento. Outra fonte de variação que deve ser levada em consideração são o método de extração/destilação e estabilização utilizados e o tempo e condições de armazenamento (Huyghebaert, 2003).

As substâncias ativas das plantas medicinais podem ser classificadas de acordo com suas características físicas, químicas ou atividade biológica. Os principais grupos existentes são: alcalóides (álcoois, aldeídos, cetonas, éters, ésteres, lactonas), glucosídeos, compostos fenólicos, saponinas, mucilagens, flavonóides, terpenóides (mono e sesquiterpenos e esteróides), taninos e óleos essenciais (Martins et al., 2000; Huyghebaert, 2003). Estas substâncias geralmente não se encontram na planta em estado puro, mas sob a forma de complexos, cujos diferentes componentes se completam e reforçam sua ação sobre o organismo em questão. Dentre esses grupos existentes, os óleos essenciais são os mais estudados como aditivos na produção animal. 


\subsection{2 Óleos essenciais}

Os óleos essenciais são uma mistura natural complexa de metabólitos secundários voláteis, isolados das plantas por processos de destilação a vapor. Os principais constituintes são os mono e sesquiterpenos, incluindo carboidratos, álcoois, éteres, aldeídos e cetonas, responsáveis pela fragrância e propriedades biológicas das plantas (Kalemba \& Kunicka, 2003). A principal diferença entre o termo extratos vegetais e óleos essenciais é o método de obtenção/extração. Os óleos essenciais, apesar de não deixarem de ser considerados extratos vegetais, são obtidos somente pelo método de extração a vapor.

Uma das vantagens da utilização dos óleos essenciais é que grande parte dos compostos ativos das plantas está presente nos óleos essenciais. Outro fator importante, visando, principalmente, os aspectos de comercialização de um produto, é que, se forem adquiridos de empresas idôneas e com rigoroso controle de qualidade, é possível assegurar a composição dos óleos a serem utilizados no produto final independentemente das condições climáticas ou locais de obtenção.

Os óleos essenciais também possuem um princípio ativo, que corresponde ao composto presente em maior quantidade no óleo. O princípio ativo de um óleo essencial pode ser encontrado em diversas plantas em menores concentrações. O timol, por exemplo, apesar de ser encontrado no tomilho (41\%) e no orégano (10\%) (Kamel, 2000), só é considerado princípio ativo do tomilho, uma vez que o principio ativo do orégano é o carvacrol (presente em $60 \%$ do óleo). Também é possível encontrar plantas com altas concentrações de princípio ativo, como a canela, que possui 90\% de cinamaldeído, e o cravo, com 80\% de eugenol (Kamel, 2000). Apesar de os princípios ativos primários (presentes em maiores quantidades na planta) serem responsáveis pelo efeito principal exercido no organismo, acredita-se que exista um efeito sinérgico, onde os componentes secundários atuariam como potencializadores dos princípios ativos primários (Kamel, 2000). Inclusive, alguns pesquisadores recomendam que, para obtenção de melhores resultados, devem ser administrados em combinações de óleos essenciais de diferentes plantas (Langhout, 2000) e reforçados pela adição dos princípios ativos mais relevantes (Kamel, 2000). 


\subsubsection{Modos de ação}

Apesar de ainda não existir um consenso sobre o exato modo de ação dos óleos essenciais, algumas hipóteses têm sido sugeridas: (1) controle de patógenos pela atividade antimicrobiana, (2) atividade antioxidante, (3) melhora na digestão, através de estímulo da atividade enzimática e absorção de nitrogênio e (4) outros efeitos relacionados com alterações na histologia do epitélio intestinal, morfometria dos órgãos e controle da produção de amônia.

Segundo Kohlert et al. (2000), os princípios ativos dos extratos vegetais são absorvidos no intestino pelos enterócitos e metabolizados rapidamente no organismo animal. Os produtos deste metabolismo são transformados em compostos polares, através da conjugação com o glicuronato, e excretados na urina. Outros princípios ainda podem ser eliminados pela respiração como $\mathrm{CO}_{2}$. A rápida metabolização e a curta meia vida dos compostos ativos levam a crer que existe um risco mínimo de acúmulo nos tecidos (Kohlert et al., 2000).

Muito embora alguns efeitos já tenham sido demonstrados, há ainda um grande desconhecimento dos mecanismos envolvidos nos processos. Langhout (2000) afirma que os extratos vegetais podem melhorar o desempenho dos animais, mas os efeitos devem ser menos pronunciados se comparados aos dos antimicrobianos. Além disso, muitas pesquisas ainda devem ser realizadas associando os princípios ativos e seus efeitos in vivo, a fim de se alcançarem ganhos expressivos no desempenho de suínos suplementados com microingredientes promotores do crescimento à base de extratos vegetais.

\subsubsection{Atividade antimicrobiana}

Existem diversos trabalhos in vitro, na literatura, avaliando a atividade antimicrobiana de diversas plantas e óleos essenciais (Mahmoud, 1994; Madsen \& Bertelsen, 1995; Cichewicz \& Thorpe, 1996; Martinez et al., 1996; Pozo, 1997; Ahmad et al., 1998; Gupta \& Sandhu, 1998; Mahrour et al., 1998; Guarrera, 1999; Mahasneh \& El-Oqlah, 1999; Navarro \& Delgado, 1999; Dorman \& Deans, 2000; Essawi \& Srour, 2000; Nascimento et al., 2000; Araújo \& Leon, 2001; Harris et al., 2001; Karanika et al., 2001; Salvat et al., 2001; Srinivasan et al., 2001; Vieira et al., 2001; Huyghebaert, 2003; Burt \& Reinders, 2003; Burt, 2004).

Os métodos de avaliação mais utilizados para determinar a atividade antimicrobiana de um óleo essencial são o de difusão em agar e o de diluição. Pelo método de difusão, é utilizado em um disco de papel Whatman e o potencial antimicrobiano do óleo é 
medido pelo tamanho da zona de inibição de crescimento do microrganismo, onde o resultado é expresso em diâmetro da zona de inibição, podendo ser em milímetros, centímetros ou valores relativos, como $0,+$ e ++. Pelo método de diluição, o resultado pode ser expresso como porcentagem de inibição de um microrganismo em relação a um tratamento controle (sem óleo essencial) ou, mais comumente, como a concentração mínima inibitória (CMI) de óleo essencial necessária para inibir o crescimento de um determinado microrganismo (Kalemba \& Kunicka, 2003). Diversos fatores podem influenciar a determinação da atividade antimicrobiana dos óleos essenciais: (1) por apresentarem baixa solubilidade em água e alta viscosidade a distribuição do óleo no meio de cultura pode ficar comprometida; (2) longos períodos de incubação também podem resultar em evaporação ou decomposição de alguns componentes presentes no óleo durante o período de teste; (3) a condição do meio de cultura (tipo e volume); (4) concentração e validade do inóculo utilizado; (5) temperatura e tempo de incubação; e (6) tipo de solvente ou agente dispersor utilizado (Kalemba \& Kunicka, 2003).

Apesar de os efeitos antimicrobianos terem sido comprovados, o mecanismo de ação dos óleos essenciais ainda é pouco compreendido. De acordo com alguns autores (Dorman \& Deans, 2000; Lambert et al., 2001), o efeito antimicrobiano de um óleo essencial está relacionado, principalmente, com a alteração da permeabilidade e integridade da membrana celular bacteriana. Existe, também, uma relação entre a estrutura química dos compostos ativos presentes no extrato vegetal e seu efeito antimicrobiano (Farag et al., 1989), sendo que, geralmente, esse efeito está relacionado com as características hidrofílicas e lipofílicas de seus constituintes (presença de compostos fenólicos) e com o tipo de microrganismo testado, principalmente em relação às características de sua membrana celular (Kalemba \& Kunicka, 2003) e variações entre as cepas de uma mesma espécie (Ouattara et al., 1997). Geralmente, bactérias gram-positivas são mais susceptíveis à ação dos óleos essenciais do que bactérias gram-negativas (Kalemba \& Kunicka, 2003). Bactérias gram-negativas apresentam maior resistência à ação de agentes antimicrobianos por terem uma superfície hidrofílica na membrana externa rica em lipopolissacarídeos, formando uma barreira contra as macromoléculas hidrofóbicas presentes em alguns óleos essenciais e antibióticos. Por isso, quanto maior a quantidade de moléculas lipofílicas presentes em um óleo essencial, maior será sua capacidade antimicrobiana sobre esse tipo de bactéria. Esse efeito foi comprovado em um estudo realizado por Dorman \& Deans (2000), onde o carvacrol e o timol (compostos fenólicos) foram capazes de atuar sobre a integridade da parede celular de bactérias gram-negativas, causando ruptura da membrana externa (Dorman \& Deans, 2000). Outros efeitos, que podem ser observados, estão 
relacionados com alteração da homeostase do $\mathrm{pH}$ e do equilíbrio de íons orgânicos, além de prejuízo na absorção de nutrientes, síntese de DNA, RNA e proteínas pelas células bacterianas (Lambert et al., 2001).

Em alguns casos, os óleos essenciais apresentam atividade antimicrobiana mais pronunciada do que alguns antibióticos (Tabak et al., 1991; Kamel, 2000). De acordo com Suresh et al. (1992), o eugenol apresentou maior efeito bactericida contra Escherichia coli, Enterobacter sakazakii e Klebsiela pneumoniae do que antibióticos e quimioterápicos como ampicilina, eritromicina e sulfametazol.

O óleo essencial de uma única planta também pode ter amplo espectro de ação bactericida in vitro. Por exemplo, o óleo essencial de canela, que contém cinamaldeído, eugenol e carvacrol (Tabak et al., 1991), apresenta atividade inibitória contra Escherichia coli, Pseudomonnas aeruginosa, Enterococcus faecalis, Staphylococcus epidermis, Staphylococcus aureus, Klebsiella pneumoniae, Salmonella typhimurium, Campylobacter e Clostridium perfringes (Chang et al., 2001).

Apesar do comprovado efeito antimicrobiano dos óleos essenciais em diversos estudos in vitro, ainda são necessários muitos estudos para comprovar este efeito in vivo.

\subsubsection{Atividade antioxidante}

O processo de oxidação é um dos fatores que mais influencia a durabilidade dos alimentos, principalmente produtos cárneos. A oxidação lipídica proporciona a formação de aroma desagradável, diminui a segurança e a qualidade do produto final pela formação de produtos potencialmente tóxicos e outros compostos durante o processamento e cozimento, e diminui a aceitação do produto por parte do consumidor (Lee \& Shibamoto, 2002). Para prevenir o processo de oxidação, têm-se adicionado antioxidantes sintéticos tais como BHT (butil hidroxitolueno) e BHA (butil hidroxianisol) nos alimentos. No entanto, cada vez mais se têm buscado alternativas ao uso de produtos sintéticos em alimentos para humanos. Com isso, diversas pesquisas têm sido realizadas (Resurreccion \& Reynolds, 1990; Moller et al., 1999; Hras et al., 2000; Milos et al., 2000; Tang et al., 2001a, 2001b, 2001c; Tanabe et al., 2002), avaliando a adição direta de extratos vegetais nos alimentos como potenciais agentes antioxidantes, inclusive em carnes e banha suína.

A atividade antioxidante dos óleos essenciais está relacionada, principalmente, com a presença de compostos fenólicos. No entanto, outros compostos, como os flavonóides 
(presentes no orégano e tomilho) e terpenóides (como timol, carvacrol e eugenol), também apresentam atividade antioxidante. Esses compostos podem interceptar e neutralizar radicais livres, impedindo a propagação do processo de oxidação (Hui, 1996). Apesar de possuírem atividade antioxidante, alguns óleos essenciais apresentam compostos com aroma extremamente acentuado, como eugenol, timol e carvacrol, por exemplo, e não podem ser adicionados em grandes quantidades nos alimentos (Madsen et al., 1997), limitando seu uso como agentes antioxidantes em certos alimentos.

Para contornar esse problema, novas linhas de pesquisa têm surgido (LopezBote et al., 1998; Youdim \& Deans, 1999, 2000; Tang et al., 2001c; Botsoglou et al., 2002a, 2002b, 2003a, 2003b, 2004; Young et al., 2003; Papageorgiou et al., 2003) para avaliar se o efeito antioxidante na carne pode ser obtido através da suplementação de extratos vegetais e óleos essenciais na dieta dos animais. E muitos trabalhos têm encontrado respostas positivas. Trabalhos recentes demonstraram que a suplementação de óleo essencial de orégano na dieta dos animais melhorou a estabilidade oxidativa da carne de frango (Botsoglou et al., 2002a, 2002b), de peru (Botsoglou et al., 2003; Papageorgiou et al., 2003) e coelhos (Botsoglou et al., 2004). Da mesma forma, no trabalho realizado por Lopez-Bote et al. (1998), a adição de oleoresinas de sálvia e alecrim na dieta de pintos aumentaram a estabilidade oxidativa dos cortes de coxa e peito. Nesse trabalho, também foi encontrada alteração na composição dos ácidos graxos no organismo e aumento da porcentagem de ácidos graxos polinsaturados (PUFA). Contudo, os polifenóis e fenóis presentes nestes óleos compensaram a possível predisposição dos tecidos à oxidação em decorrência da alta porcentagem de ácidos graxos polinsaturados.

A partir desses trabalhos, é possível sugerir que a inclusão de óleos essenciais na dieta dos animais pode influenciar a estabilidade oxidativa da carne após o abate. Entretanto, são necessários mais estudos para comprovar o efeito antioxidante dos óleos essenciais, de forma que traga benefícios tanto para o desempenho animal quanto para a indústria processadora de carnes.

\subsubsection{Estímulo da atividade enzimática}

Acredita-se que os extratos vegetais possam estimular a produção de saliva e de suco gástrico e pancreático, influenciando positivamente a secreção de enzimas digestivas e melhorando a digestibilidade dos nutrientes (Mellor, 2000; Jones, 2002). Essa propriedade geralmente está associada à presença de taninos ou substâncias pungentes presentes nos extratos 
vegetais (Mellor, 2000). Em humanos, sabe-se que os componentes pungentes das ervas aromáticas (pimenta, cravo, canela, etc.) aumentam a secreção de saliva e suco gástrico devido ao estímulo do sistema nervoso central, proporcionado pelo cheiro e sabor (Sreenivasamurthy \& Krishnamurthy, 1959). Com um aumento na produção de suco gástrico, haverá redução do pH estomacal, formando uma barreira natural contra microrganismos patogênicos e propiciando condições adequadas para a atividade das enzimas digestivas do estômago, como a pepsina (Jones, 2002). Uma digestão adequada dos alimentos refletirá positivamente na microbiota intestinal, absorção de nutrientes, taxa de passagem do alimento e, consequentemente, na saúde e desempenho do animal (Jones, 2001).

Alguns estudos foram realizados para avaliar o efeito da suplementação de extratos vegetais sobre a secreção e a mudança na composição da bile (Ganesh-Baht et al., 1984; Sambaiah \& Srinivasan, 1991) e produção de enzimas digestivas (Platel \& Srinivasan, 1996) de ratos suplementados com diferentes óleos essenciais. A capsaicina (princípio ativo da pimenta) foi capaz de estimular a salivação (produção de amilase) e aumentar a secreção das enzimas pancreáticas, da sacarase e da maltase de ratos (Platel \& Srinivasan, 1996; Wang \& Bourne, 1998), enquanto que o cinamaldeído (princípio ativo da canela) apresentou ação estimulante sobre as enzimas pancreáticas (Wang \& Bourne, 1998) e aumentou o tempo de retenção do alimento no estômago por ter reduzido a motilidade gástrica em suínos (Manzanilla et al., 2004). Em frangos, a suplementação de uma combinação de óleos essenciais aumentou a atividade da amilase do conteúdo intestinal aos 21 dias de idade, mas nenhum efeito foi observado aos 40 dias (Lee et al., 2003a).

O efeito estimulante na produção de enzimas e secreções intestinais é considerado uma das principais explicações para a melhora da digestibilidade dos nutrientes encontrada em alguns trabalhos (Platel \& Srinivasan, 1996; Wang \& Bourne, 1998; Hernández et al., 2004). Entretanto, deve-se levar em consideração outros aspectos também, como alterações na morfometria dos órgãos, na histologia do epitélio intestinal e na microbiota intestinal, que também podem contribuir para o processo digestivo.

\subsubsection{Outros efeitos}

A altura das vilosidades e profundidade de criptas do epitélio intestinal é um indicador importante da qualidade do processo digestivo, pois está diretamente relacionada com a capacidade de absorção da mucosa intestinal (Manzanilla et al., 2004). A altura das vilosidades 
reflete o balanço entre a atividade mitótica das células da cripta e o processo de descamação causado por agentes agressores (Manzanilla et al., 2004). Os poucos trabalhos encontrados na literatura sugerem que os extratos vegetais podem ter efeito benéfico sobre a histologia do epitélio intestinal, mas os resultados ainda são pouco conclusivos. Foi encontrada uma redução na profundidade de cripta de frangos suplementados com tomilho (Demir et al., 2003) e aumento (não significativo) da altura da vilosidade e relação altura da vilosidade/profundidade de cripta de suínos suplementados com uma combinação de óleos essenciais (Utiyama, 2004). Contudo em outros trabalhos (Manzanilla et al., 2004) esses efeitos não foram observados.

Em relação à morfometria dos órgãos, alguns trabalhos relatam redução do peso relativo do intestino (Alçiçek et al., 2004) e aumento no peso do pâncreas (Lewis et al., 2004) pela suplementação de óleos essenciais na dieta de frangos, enquanto outros (Lee et al., 2003b; Hernández et al., 2004) não observaram efeito significativo.

Outro efeito que tem sido estudado está relacionado com a produção de ácidos graxos voláteis e fermentação cecal. Os ácidos graxos voláteis são os principais produtos finais do metabolismo bacteriano no intestino grosso de suínos. No trabalho realizado por Manzanilla et al. (2004), a inclusão de uma combinação de extratos vegetais na dieta de suínos alterou o perfil de ácidos graxos do ceco, através do aumento na proporção de acetato e diminuição na proporção de butirato e valerato. Em experimentos in vitro, foi observada uma redução na produção de gás (fermentação cecal) pela adição de óleo essencial de tomilho (Piva et al., 2004; Shanmugavelu et al., 2004), indicando sensibilidade dos microrganismos ao óleo testado. Da mesma forma, Piva et al. (2002a, 2002b) demonstraram que o carvacrol pode reduzir a população de Enterobacteriaceae spp. em suínos, reduzindo também a produção de amônia, tóxica às células do epitélio intestinal. Assim, poderia haver uma ação protetora do epitélio intestinal, melhorando a absorção de nutrientes.

Pode-se observar que, por se tratar de um assunto relativamente recente, os resultados obtidos com a suplementação de extratos vegetais para suínos são pouco elucidativos e ainda muito contraditórios. São necessários mais estudos para que se chegue a um consenso sobre o real modo de ação dos óleos essenciais e sua melhor aplicação na produção animal. 


\section{MATERIAL E MÉTODOS}

Foram conduzidos três experimentos de 35 dias de duração na creche experimental do Setor de Suinocultura do Departamento de Zootecnia da ESALQ/USP. O Experimento I, além de avaliar o desempenho e a frequência de diarréia dos animais, avaliou os efeitos de antimicrobianos e extratos vegetais sobre a digestibilidade dos nutrientes, morfometria de órgãos, histologia de epitélio intestinal e sobre a microbiologia intestinal de leitões recémdesmamados. Os Experimentos II e III avaliaram o desempenho e a frequência de diarréia dos animais, sendo que, no Experimento III, também foi feito o abate dos animais para repetição da análise de morfometria dos órgãos.

\subsection{Instalações experimentais e animais}

A sala de creche utilizada possui 20 baias metálicas suspensas, dispostas em quatro faixas de cinco baias. Cada baia possui uma área de $1,80 \mathrm{~m}^{2}$, sendo provida de comedouro automático, bebedouro tipo chupeta e aquecimento proporcionado por lâmpada infravermelha de 250W. A área abaixo do bebedouro é constituída de piso vazado, enquanto que o restante é compacto, correspondente à área adjacente ao comedouro.

Foram utilizados 120 leitões Dalland, sendo 40 animais por experimento. Os animais apresentaram idades iniciais e finais de 21 e 56 dias, e peso médio inicial e final de 5,41 $\pm 0,27$ e 17,62 $\pm 2,32 \mathrm{~kg}$, respectivamente. Cada baia foi composta por dois animais (unidade experimental), sendo um macho castrado e uma fêmea. Todos os animais foram adquiridos de uma granja comercial em Itu, SP. 


\subsection{Escolha e preparo dos extratos vegetais}

Optou-se pela utilização dos extratos vegetais sob a forma de óleos essenciais, pois apresentam maior constância na composição, principalmente quando adquiridos de empresa especializada (Givaudan) e com alto controle de qualidade. Os óleos essenciais são extraídos de diversas plantas e são homogeneizados até a obtenção da composição padrão de cada óleo, garantindo, assim, a constância de seus componentes independente da época do ano ou local de extração. Como os óleos essenciais são compostos altamente voláteis, foi necessário submetê-los a um processo chamado de microencapsulamento, que consiste no encapsulamento dos óleos essenciais para que sejam preservados até o momento da ingestão pelos animais. Além disso, esse procedimento também tem como objetivo minimizar o sabor dos óleos na dieta e liberá-los, de forma controlada, no estômago do animal.

Para a escolha dos óleos essenciais, foram determinadas em pesquisas bibliográficas as três plantas que apresentavam alto potencial antimicrobiano sobre o maior número de microrganismos. Os óleos essenciais escolhidos foram o de cravo, tomilho e orégano. Além disso, foram adicionados os princípios ativos do cravo (eugenol) e do orégano (carvacrol) nas mesmas quantidades que os óleos. O princípio ativo do tomilho (timol) não pôde ser adicionado por estar disponível somente sob a forma de pó (também volátil), o que impossibilitou o encapsulamento. As cápsulas foram desenvolvidas para conter quantidades iguais dos três óleos essenciais, acrescidos dos princípios ativos correspondentes no caso do cravo e do orégano, correspondendo a $20 \%$ do produto final encapsulado (Tabela 1).

Tabela 1. Composição do extrato vegetal encapsulado utilizado nos experimentos

\begin{tabular}{lc}
\hline Componente & $\%$ \\
\hline Óleo vegetal (mistura de triglicérides) & 60,00 \\
Gelatina & 7,50 \\
Dióxido de silício (anti-umectante) & 7,50 \\
Água & 3,40 \\
Álcool & 1,60 \\
Óleo essencial de cravo + eugenol & 6,66 \\
Óleo essencial de orégano + carvacrol & 6,66 \\
Óleo essencial de tomilho & 6,66 \\
TOTAL & 100,00 \\
\hline
\end{tabular}


Para assegurar que não houvesse prejuízo no consumo por parte dos animais, foram realizados testes de consumo com diferentes concentrações dos óleos encapsulados na dieta. A partir dos resultados, foi possível estabelecer os três níveis de extratos vegetais a serem utilizados nas dietas experimentais.

\subsection{Teste de consumo}

Para a realização do teste de consumo, foram utilizadas quatro baias contendo dois leitões em cada baia, com peso médio inicial de 5,36 \pm 0,17 kg. Foi feita a avaliação diária do consumo de ração dos animais durante quatro dias. Em cada dia de teste os animais receberam, alternadamente, os quatro tratamentos (Tabela 2).

Tabela 2. Média de consumo diário de ração (kg/dia) de leitões recebendo dieta controle e com diferentes concentrações de extratos vegetais encapsulados

\begin{tabular}{ccccc}
\hline Dia de & & \multicolumn{2}{c}{ Tratamento } \\
experimentação & Controle & $700 \mathrm{ppm}$ & $1400 \mathrm{ppm}$ & $2100 \mathrm{ppm}$ \\
\hline 1 & 0,231 & 0,303 & 0,250 & 0,253 \\
2 & 0,353 & 0,274 & 0,354 & 0,291 \\
3 & 0,433 & 0,440 & 0,371 & 0,460 \\
4 & 0,513 & 0,538 & 0,530 & 0,470 \\
Média & 0,382 & 0,389 & 0,376 & 0,368 \\
\hline
\end{tabular}

Como não houve prejuízo no consumo, optou-se por utilizar a inclusão de 700, 1400 e 2100 ppm de produto encapsulado na dieta.

\subsection{Tratamentos e dietas basais}

Em todos os experimentos foram testados cinco tratamentos:

- Tratamento controle: dieta basal;

- Tratamento antimicrobiano: dieta basal +50 ppm bacitracina de zinco +50 ppm de olaquindox + 50 ppm de colistina;

- Tratamento extrato vegetal A: dieta basal + 700 ppm de extratos vegetais (cravo+eugenol, orégano+carvacrol e tomilho) encapsulados; 
- Tratamento extrato vegetal B: dieta basal + 1400 ppm de extratos vegetais (cravo+eugenol, orégano+carvacrol e tomilho) encapsulados;

- Tratamento extrato vegetal C: dieta basal + 2100 ppm de extratos vegetais (cravo+eugenol, orégano+carvacrol e tomilho) encapsulados;

Em todos experimentos, foram utilizadas duas dietas basais durante o período experimental. A dieta basal pré-inicial foi fornecida do $1^{\circ}$ ao $14^{\circ}$ dia de experimento, enquanto que a dieta basal inicial, do $15^{\circ}$ ao $35^{\circ}$ dia. As composições percentuais das dietas basais, assim como os valores calculados de alguns nutrientes, podem ser encontrados na Tabela 3. 
Tabela 3. Composição percentual e valores calculados das dietas basais

\begin{tabular}{|c|c|c|}
\hline Ingrediente & $\begin{array}{l}\text { Ração Pré-inicial } \\
\text { (1a } 14 \text { dias) }\end{array}$ & $\begin{array}{l}\text { Ração Inicial } \\
\text { (15 a } 35 \text { dias) }\end{array}$ \\
\hline Milho & 59,269 & 63,329 \\
\hline Farelo de soja (46\%) & 15,171 & 23,500 \\
\hline Produto lácteo ( $40 \%$ de lactose $)^{1}$ & 10,532 & 2,673 \\
\hline Lactose & 6,000 & 2,992 \\
\hline Plasma sanguíneo ${ }^{2}$ & 4,300 & 2,000 \\
\hline Fosfato bicálcico & 1,227 & 1,497 \\
\hline Calcário & 1,095 & 1,024 \\
\hline Óleo de soja & 0,800 & 1,500 \\
\hline L-Lisina.HCl (78\%) & 0,577 & 0,427 \\
\hline L-Treonina (98,5\%) & 0,224 & 0,162 \\
\hline DL-Metionina (99\%) & 0,215 & 0,145 \\
\hline L-Triptofano (98\%) & 0,081 & 0,016 \\
\hline Cloreto de colina (60\%) & 0,100 & 0,100 \\
\hline Suplemento vitamínico ${ }^{3}$ & 0,100 & 0,100 \\
\hline Suplemento mineral ${ }^{4}$ & 0,100 & 0,100 \\
\hline Sal & 0,000 & 0,225 \\
\hline Caulim e/ou promotor do crescimento & 0,210 & 0,210 \\
\hline \multicolumn{3}{|l|}{ Valores calculados: } \\
\hline Energia metabolizável (kcal/kg) & 3.400 & 3.300 \\
\hline Proteína bruta (\%) & 20,00 & 19,50 \\
\hline Lisina total (\%) & 1,50 & 1,33 \\
\hline Lisina digestível (\%) & 1,34 & 1,19 \\
\hline Treonina digestível (\%) & 0,86 & 0,77 \\
\hline Triptofano digestível (\%) & 0,27 & 0,21 \\
\hline Metionina digestível (\%) & 0,46 & 0,39 \\
\hline Metionina + cistina digestível (\%) & 0,79 & 0,69 \\
\hline Lactose (\%) & 11,76 & 4,00 \\
\hline Cálcio (\%) & 0,85 & 0,87 \\
\hline Fósforo disponível (\%) & 0,45 & 0,42 \\
\hline
\end{tabular}

${ }^{1}$ Produto comercial: Nuklospray K-10;

${ }^{2}$ Produto comercial: AP920;

${ }^{3}$ Quantidades supridas por kg de ração: vit. A, 6000 UI; vit. $\mathrm{D}_{3}$, 1500 UI; vit. E, 15 UI; vit. $\mathrm{K}_{3}, 1,5$ mg; tiamina, 1,35 mg; riboflavina, 4 mg; piridoxina, 2 mg; vit. $\mathrm{B}_{12}, 0,02 \mathrm{mg}$; ácido nicotínico, $20 \mathrm{mg}$; ácido fólico, 0,6 mg; biotina, 0,8 mg; ácido pantotênico, 9,35 mg; selênio 0,3 mg;

${ }^{4}$ Quantidades supridas por kg de ração: iodo, 1,5 mg; cobalto, $1 \mathrm{mg}$; cobre, $10 \mathrm{mg}$; zinco $100 \mathrm{mg}$; ferro, $100 \mathrm{mg}$; manganês, 40 mg; 


\subsection{Experimento I}

Foram utilizados 40 leitões Dalland dos 21 aos 56 dias de idade, com peso inicial e final de 5,51 \pm 0,32 e 17,69 \pm 2,27 kg, respectivamente, distribuídos em 20 baias (um macho castrado e uma fêmea por baia) de acordo com o peso inicial, totalizando quatro blocos (quatro repetições por tratamento). O delineamento experimental foi o de blocos casualizados.

Os animais foram alimentados à vontade durante todo período experimental de 35 dias. As variáveis de desempenho (consumo de ração, ganho diário de peso e conversão alimentar) foram calculadas a partir de pesagens e quantificações das sobras de ração feitas periodicamente. Também foi avaliada, diariamente, a frequência de diarréia dos animais.

O ensaio de digestibilidade foi realizado durante os últimos 14 dias de experimento. Ao final do experimento, os animais passaram por um período de $15 \mathrm{~h}$ de jejum e foram abatidos para coleta de dados referentes a morfometria dos órgãos e coleta de amostras para as análises microbiológicas e histológicas. O jejum foi feito para diminuir a presença de resíduos no epitélio intestinal e não prejudicar as análises histológicas e microbiológicas.

\subsubsection{Digestibilidade aparente dos nutrientes}

Foi empregado o método da coleta parcial de fezes, utilizando o óxido crômico $\left(\mathrm{Cr}_{2} \mathrm{O}_{3}\right)$ como marcador dietético, adicionado às dietas experimentais na concentração de $0,05 \%$. A ração marcada foi fornecida a partir do $22^{\circ}$ dia de experimento. A coleta de fezes foi feita durante quatro dias (manhã e tarde) e teve início após oito dias de fornecimento do marcador na dieta dos animais ( $30^{\circ} \mathrm{dia}$ ). As amostras de fezes coletadas foram imediatamente acondicionadas e congeladas em sacos plásticos identificados.

Posteriormente, as amostras de fezes foram descongeladas e homogeneizadas, retirando-se uma subamostra de, aproximadamente, $500 \mathrm{~g}$. Estas subamostras foram secas em estufas de circulação de ar forçada, a $65^{\circ} \mathrm{C}$ e durante 72 horas, e moídas em moinho tipo Willey, em peneira crivada de $1 \mathrm{~mm}$. As amostras de fezes e rações foram enviadas para análise de matéria seca, energia bruta e de óxido crômico.

A determinação da porcentagem de óxido crômico nas amostras foi feita no Laboratório de Instrumentação Nuclear do Centro de Energia Nuclear na Agricultura da Universidade de São Paulo pela técnica de fluorescência de raios X por dispersão de energia (Zucchi \& Nascimento Filho, 1995; Nascimento Filho et al., 1997). Já as análises 
bromatológicas foram realizadas no Laboratório de Bromatologia da FZEA/USP. A determinação de energia bruta foi feita em bomba calorimétrica automática modelo PARR 1261. A análise de matéria seca foi realizada de acordo com a Association of Official Analytical Chemists (AOAC, 1980). Todas as amostras foram analisadas em duplicata.

Para a determinação dos coeficientes de digestibilidade aparente (CDap) da matéria seca e energia bruta, foi utilizada a seguinte fórmula:

$$
\text { CDap }(\%)=100-100 \times \frac{(\% \text { marcador na dieta })}{(\% \text { marcador nas fezes })} \times \frac{(\% \text { nutriente nas fezes })}{(\% \text { nutriente na dieta })},
$$

\subsubsection{Morfometria dos órgãos}

Para a análise de morfometria, foi abatido um animal por unidade experimental no $35^{\circ}$ dia dos Experimentos I e III, totalizando oito repetições por tratamento para essa variável. $\mathrm{O}$ animal foi escolhido de acordo com o peso vivo, sendo utilizado aquele que apresentava o peso mais próximo da média dos demais, independente do sexo. Este critério foi adotado, pois ainda existe pouca diferença entre sexo nessa fase a ponto de comprometer os resultados de morfometria.

Após o sacrifício, foram retirados e pesados os órgãos digestivos (trato gastrintestinal total, estômago vazio, pâncreas, fígado, vesícula biliar, intestino delgado vazio, intestino grosso vazio, ceco e colo vazios) e os não digestivos (baço, rins, pulmões e coração). Também foi feita a medição do comprimento do intestino delgado dos animais. De posse dos dados, foram calculados os pesos relativos dos órgãos e o comprimento relativo do intestino delgado, considerando o peso vivo dos animais no momento do abate, e a relação peso:comprimento do intestino delgado.

\subsubsection{Histologia do epitélio intestinal}

\subsubsection{Microscopia ótica}

Imediatamente após a retirada e pesagem do trato gastrintestinal, segmentos de cerca de $5 \mathrm{~cm}$ de comprimento do duodeno (até $15 \mathrm{~cm}$ do esfíncter estomacal), jejuno (1,5 $\mathrm{m}$ da junção do íleo com o intestino grosso) e íleo (20 cm da junção com o intestino grosso) foram 
retirados, abertos ao longo do mesentério, fixados em papelão e acondicionados em líquido fixador de Bouin. As amostras foram retiradas imediatamente após o abate para não prejudicar a integridade do epitélio intestinal. Posteriormente, as amostras foram transportadas para o Laboratório de Citologia, Histologia e Embriologia da Faculdade de Zootecnia e Engenharia de Alimentos da Universidade de São Paulo (FZEA/USP), onde foram emblocadas em historesina. Após a secagem dos blocos, foram feitos os cortes de $3 \mu \mathrm{m}$ em micrótomo automático.

Para cada amostra, foram recolhidos em uma lâmina cinco cortes não seriados (30 cortes de intervalo). Essas lâminas foram submetidas à coloração por hematoxilina e eosina. As medições de altura de vilosidade, profundidade de cripta, relação altura de vilosidade/profundidade de cripta foram feitas de acordo com metodologia descrita por Jin et al. (1994), através de imagens geradas em um microscópio ZEISS Axioplan 2 e captadas digitalmente por uma câmera. O software utilizado para a análise das imagens foi o KS 400, sendo este capaz de fazer medições de comprimentos e áreas da imagem gerada.

\subsubsection{Microscopia eletrônica de varredura}

Simultaneamente à retirada de amostras para análise em histologia óptica, foram retiradas amostras de $0,25 \mathrm{~cm}^{2}(0,50 \times 0,50 \mathrm{~cm})$ do duodeno, jejuno e íleo para análise em microscopia eletrônica de varredura. No momento da coleta, as amostras foram lavadas, mergulhadas em solução fixadora de Karnovisk (duas horas) e armazenadas em definitivo em solução tampão fosfato 0,1 M (temperatura de $3^{\circ} \mathrm{C}$ ). Posteriormente, foram transportadas ao Núcleo de Apoio à Pesquisa/Microscopia Eletrônica Aplicada à Pesquisa Agropecuária da ESALQ/USP, onde foram pós-fixadas em tetróxido de ósmio $\left(\mathrm{OsO}_{4}\right)$. Ao final da fixação, foi feita a secagem ao ponto crítico, a metalização das amostras e a visualização em um microscópio eletrônico de varredura em pressão variável LEO 435 VP. Foram selecionadas as melhores imagens de cada amostra para análise visual das vilosidades de acordo com o tratamento. A preparação das amostras foi feita com base na metodologia preconizada pelo próprio laboratório.

\subsubsection{Microbiologia intestinal}

Para análise microbiológica, foram coletados, separadamente, os conteúdos do intestino delgado (duodeno, jejuno e íleo) e do reto, pelo método de raspagem. As amostras foram mantidas refrigeradas até o momento da análise. Já as amostras de conteúdo do reto 
(análise de Clostridium perfringens) foram acondicionados em jarras de anaerobiose, providas de geradores de $\mathrm{CO}_{2}$, em temperatura ambiente. Após a coleta, as amostras seguiram para um laboratório comercial especializado (Labor 3) para análise de microrganismos totais, grampositivos totais, gram-negativos totais, Bacillus spp., Streptococcus spp., Staphylococcus spp., Clostridium perfringens e E.coli. através da técnica de plaqueamento. A identificação e quantificação do gênero Campylobacter coli. foi feita no Laboratório de Doenças Bacterianas da Reprodução do Instituto Biológico/SP.

\subsection{Experimentos II e III}

Nos experimentos II e III, foram medidas as variáveis de desempenho e frequência de diarréia. Da mesma forma que no Experimento I, foram utilizados 40 leitões Dalland em cada experimento, distribuídos em 20 baias (um macho castrado e uma fêmea por baia) de acordo com o peso, totalizando 4 blocos (4 repetições por tratamento).

Para análise final dos dados de desempenho e frequência de diarréia, cada um dos três experimentos foi considerado uma repetição no tempo, totalizando 12 blocos ou 12 repetições por tratamento para essas variáveis. As temperaturas máximas e mínimas diárias foram monitoradas diariamente e os animais receberam água e ração à vontade.

\subsubsection{Desempenho}

As variáveis de desempenho (consumo diário de ração, ganho diário de peso e conversão alimentar) foram calculadas a partir de pesagens e quantificações das sobras de ração feitas periodicamente.

\subsubsection{Frequência de diarréia}

A frequência de diarréia foi analisada diariamente, atribuindo notas de 1 a 4 para cada animal de acordo com a consistência das fezes, sendo: (1) fezes líquidas, (2) fezes líquidas/pastosas, (3) fezes pastosas e (4) fezes sólidas. Apenas os escores 1 e 2 indicavam a ocorrência de diarréia. Assim, pôde-se calcular a porcentagem de dias com ocorrência de diarréia nos períodos de 1 a 14 e 1 a 35 dias de experimentação. 


\subsection{Delineamento experimental}

Nos três experimentos, o delineamento experimental utilizado foi o de blocos casualizados. Em cada experimento foram testados cinco tratamentos com 4 repetições (blocos) por tratamento.

Para as variáveis de desempenho e frequência de diarréia, foram realizados três experimentos no tempo, totalizando 12 repetições (blocos) para cada um dos cinco tratamentos. Para a análise de morfometria, foram utilizados os dados de dois experimentos, totalizando 8 repetições por tratamento.

\subsection{Análise dos dados}

Os dados foram analisados pelo SAS LAB para verificação da adequação dos dados ao modelo linear. Posteriormente, foi feita análise de variância pelo PROC GLM (General Linear Models) do SAS (Statistical Analysis System, 2001). Para complementar a análise inicial, os dados de ganho diário de peso e consumo diário de ração também foram submetidos à análise multivariada.

Os dados referentes à microbiologia intestinal foram transformados pela função $y=\log x$, onde $x$ é o número de Unidades Formadoras de Colônias/g de amostra. Já os dados de freqüência de diarréia foram transformados pela função $y=\operatorname{arcsen} \sqrt{(p / 100)}$, sendo "p" a porcentagem de dias com diarréia, de acordo com o recomendado por Barbin (2003).

O modelo matemático principal $\left(\mathrm{y}_{\mathrm{ijk}}=\mu+\mathrm{b}_{\mathrm{i}}+\mathrm{t}_{\mathrm{k}}+\mathrm{e}_{\mathrm{ijk}}\right)$ incluiu os fatores bloco (b), tratamento (t) e erro experimental (e). Para as variáveis de desempenho, frequência de diarréia e morfometria, também foram considerados os efeitos de experimento no modelo principal. A interação tratamento*experimento não foi significativa, por isso foi retirada do modelo.

Foram realizados contrastes de interesse para a comparação das médias e análise de polinômios ortogonais para os níveis crescentes dos extratos vegetais na dieta. 


\section{RESULTADOS E DISCUSSÃO}

\subsection{Digestibilidade aparente dos nutrientes}

A Tabela 4 mostra as médias dos coeficientes de digestibilidade aparente da matéria seca e energia bruta em função dos tratamentos. O Apêndice 1 mostra os resultados das análises bromatológicas e de cromo das amostras de fezes e ração.

Tabela 4. Médias dos coeficientes de digestibilidade aparente (\%) para matéria seca e energia bruta, em função dos tratamentos

\begin{tabular}{|c|c|c|}
\hline \multirow{2}{*}{ Tratamentos $^{1}$} & \multicolumn{2}{|c|}{ Coeficientes de digestibilidade aparente (\%) } \\
\hline & Matéria seca ${ }^{2,3}$ & Energia bruta \\
\hline $\mathrm{C}$ & $73,02 \pm 0,86$ & $73,47 \pm 1,01$ \\
\hline A & $73,05 \pm 1,62$ & $72,61 \pm 2,35$ \\
\hline $\mathrm{Ea}$ & $72,87 \pm 2,44$ & $72,39 \pm 1,96$ \\
\hline $\mathrm{Eb}$ & $75,60 \pm 0,86$ & $73,76 \pm 1,51$ \\
\hline Ec & $76,81 \pm 1,67$ & $75,79 \pm 2,57$ \\
\hline $\operatorname{Pr}>\mathrm{F}$ & 0,0057 & 0,1165 \\
\hline $\mathrm{CV}(\%)^{4}$ & 1,95 & 2,41 \\
\hline
\end{tabular}

${ }^{1} \mathrm{C}=$ controle; $\mathrm{A}=$ antimicrobiano;Ea, Eb e Ec =700, 1400, 2100 ppm de extrato vegetal, respectivamente

${ }^{2}$ Contrastes significativos: Controle x Extrato e Antimicrobiano x Extratos

${ }^{3}$ Efeito linear $(\mathrm{P}<0,05)$ para os níveis crescentes de extrato na dieta, onde $\mathrm{Y}=1,409 \mathrm{x}+71,055 ; \mathrm{R}^{2}=0,88$

${ }^{4}$ Coeficiente de variação

A inclusão de níveis crescentes de extrato vegetal na dieta promoveu o aumento $(\mathrm{P}<0,05)$ da digestibilidade aparente da matéria seca em relação ao tratamento controle e antimicrobiano. Estes resultados estão de acordo com os obtidos por Hernández et al. (2004) em um estudo com frangos, onde foi observado um aumento no coeficiente de digestibilidade da matéria seca, em relação ao tratamento controle, quando da suplementação da dieta com extratos vegetais à base de orégano, canela e pimenta (T1) e sálvia, tomilho e alecrim (T2), sendo encontradas diferenças significativas para as fases inicial (70,32 vs 71,40 para T1 e 74,49\% para 
T2) e terminação (63,55 vs 72,20 para T1 e 69,36\% para T2). Entretanto, diferentemente dos resultados apresentados, em outro trabalho (Lee et al., 2003a) não foi observado efeito significativo de extratos vegetais sobre a digestibilidade dos nutrientes em frangos de corte. De acordo com os autores, essa ausência de efeito pode ser atribuída ao fato de a dieta utilizada ser altamente digestível e um aumento na digestibilidade dos nutrientes seria praticamente impossível ou dificilmente detectada.

De acordo com a literatura, a adição de extratos vegetais na dieta pode aumentar a secreção de saliva, suco gástrico, suco pancreático, sais biliares e enzimas do intestino delgado em ratos (Sambaiah \& Srinivasan, 1991; Platel \& Srinivasan, 1996; Wang \& Bourne, 1998). A presença dessas substâncias na dieta proporciona um aumento na produção de pepsina e ácido gástrico pelo organismo, contribuindo para uma redução do pH estomacal e do intestino delgado, estimulando a secreção pancreática (Mellor, 2000). Essa pode ser uma das explicações para o tratamento com extrato vegetal ter acarretado uma melhora na digestibilidade aparente da matéria seca.

\subsection{Desempenho}

Os resultados de peso vivo, consumo diário de ração, ganho diário de peso e conversão alimentar nas fases: 1 a 14 e 1 a 35 dias de experimento encontram-se na Tabela 5 e 6 , respectivamente. Os Apêndices 2 a 5 apresentam as médias por unidade experimental do peso vivo, consumo diário de ração, ganho diário de peso e conversão alimentar, respectivamente. Já os Apêndices 6 a 8 apresentam as temperaturas diárias máximas e mínimas para os Experimentos I, II e III, respectivamente. 
Tabela 5. Médias de peso vivo aos 14 dias (P14, kg), consumo diário de ração (CDR, kg/dia), ganho diário de peso (GDP, kg/dia) e conversão alimentar (CA) para o período de 1 a 14 dias de experimentação

\begin{tabular}{ccccc}
\hline Tratamentos $^{1}$ & $\begin{array}{c}\text { P14 } \\
(\mathrm{kg})\end{array}$ & $\begin{array}{c}\mathrm{CDR}^{2} \\
(\mathrm{~kg} / \mathrm{dia})\end{array}$ & $\begin{array}{c}\text { GDP } \\
(\mathrm{kg} / \mathrm{dia})\end{array}$ & CA \\
\hline C & 7,642 & 0,527 & 0,159 & 3,414 \\
$\mathrm{~A}$ & 8,469 & 0,632 & 0,218 & 2,949 \\
Ea & 7,548 & 0,522 & 0,151 & 3,715 \\
Eb & 7,535 & 0,497 & 0,151 & 3,444 \\
Ec & 8,007 & 0,558 & 0,185 & 3,176 \\
$\mathrm{Pr}>\mathrm{F}$ & 0,0005 & 0,0023 & 0,0004 & 0,0737 \\
$\mathrm{CV}^{3}(\%)$ & 7,11 & 14,88 & 22,83 & 19,85 \\
\hline
\end{tabular}

${ }^{1} \mathrm{C}=$ controle; A=antimicrobiano;Ea, Eb e Ec =700, 1400, 2100 ppm de extrato vegetal, respectivamente

${ }^{2}$ Contrastes significativos: Controle x Antimicrobiano e Antimicrobiano x Extratos

${ }^{3}$ Coeficiente de variação

Tabela 6. Médias de peso vivo aos 35 dias (P35, kg), consumo diário de ração (CDR, kg/dia), ganho diário de peso (GDP, kg/dia) e conversão alimentar (CA) para o período de 1 a 35 dias de experimentação

\begin{tabular}{ccccc}
\hline Tratamentos $^{1}$ & $\begin{array}{c}\mathrm{P35}^{2} \\
(\mathrm{~kg})\end{array}$ & $\begin{array}{c}\mathrm{CDR}^{2} \\
(\mathrm{~kg} / \mathrm{dia})\end{array}$ & $\begin{array}{c}\text { Gariáveis } \\
(\mathrm{kg} / \mathrm{dia})\end{array}$ & CA \\
\hline $\mathrm{C}$ & 17,576 & 0,970 & 0,347 & 2,821 \\
$\mathrm{~A}$ & 19,488 & 1,090 & 0,402 & 2,710 \\
$\mathrm{Ea}$ & 17,175 & 0,917 & 0,335 & 2,745 \\
Eb & 16,228 & 0,864 & 0,309 & 2,784 \\
Ec & 17,635 & 0,937 & 0,349 & 2,684 \\
$\mathrm{Pr}>\mathrm{F}$ & 0,0068 & 0,0059 & 0,0065 & 0,8376 \\
$\mathrm{CV}^{3}(\%)$ & 11,55 & 14,94 & 16,65 & 11,60 \\
\hline
\end{tabular}

${ }^{1} \mathrm{C}=$ controle; A=antimicrobiano;Ea, Eb e Ec =700, 1400, 2100 ppm de extrato vegetal, respectivamente

${ }^{2}$ Contrastes significativos: Controle x Antimicrobiano e Antimicrobiano x Extratos

${ }^{3}$ Coeficiente de variação

Antes de realizar a comparação de médias, foi feita uma análise multivariada das variáveis ganho diário de peso e consumo diário de ração. Na Tabela 7 são apresentadas as probabilidades (valores de P) obtidas nessa análise. Pode-se concluir que existe diferença entre os tratamentos para essas variáveis. 
Tabela 7. Valores de P obtidos nos testes estatísticos da análise multivariada

\begin{tabular}{lcccc}
\hline \multirow{2}{*}{ Combinação de variáveis $^{1}$} & \multicolumn{3}{c}{ Teste estatístico - Valores de P } \\
& Wilks' Lambda & $\begin{array}{c}\text { Pillai's } \\
\text { Trace }\end{array}$ & $\begin{array}{c}\text { Hotelling-Lawley } \\
\text { Trace }\end{array}$ & $\begin{array}{c}\text { Roy's Greatest } \\
\text { Root }\end{array}$ \\
\hline GDP e CDR (1-14 dias) & 0,0037 & 0,0066 & 0,0028 & 0,0003 \\
GDP e CDR (1-35 dias) & 0,0322 & 0,0442 & 0,0262 & 0,0028 \\
\hline
\end{tabular}

${ }^{1}$ Ganho diário de peso e consumo diário de ração no período de 1-14 e 1-35 dias de experimento

Mesmo após o desdobramento dos graus de liberdade do fator nível de extrato vegetal na dieta em seus componentes individuais de regressão, pelos polinômios ortogonais, não foi observada $(\mathrm{P}>0,05)$ qualquer resposta do ganho diário de peso e do consumo diário de ração dos leitões.

Durante os períodos de 1 a 14 e 1 a 35 dias de experimentação, o tratamento antimicrobiano apresentou melhores resultados $(\mathrm{P}<0,05)$ de peso vivo, consumo diário de ração e ganho diário de peso que o tratamento controle e os diferentes níveis de extratos vegetais na dieta. A diferença de desempenho dos animais do tratamento antimicrobiano e do tratamento controle demonstra o alto grau de desafio ao qual os animais foram submetidos, pois quanto maior o desafio, maior o efeito dos antimicrobianos sobre o desempenho dos animais em relação aos animais controle (Menten, 2002).

A conversão alimentar dos leitões não foi influenciada $(\mathrm{P}>0,05)$ pelos tratamentos em nenhum dos períodos considerados, muito embora os melhores resultados numéricos tenham sido observados para os animais do tratamento antimicrobiano e do tratamento com o maior nível de inclusão de extrato vegetal.

Apesar de as diferenças entre tratamentos não terem sido significativas, nota-se que os resultados de desempenho foram melhores à medida que se aumentou o nível de inclusão dos extratos vegetais na dieta. O tratamento com 2100 ppm de extrato vegetal (Ec) apresentou resultados intermediários de desempenho entre o tratamento antimicrobiano e controle, principalmente no período de 1 a 14 dias de experimentação.

O melhor desempenho dos animais que receberam antimicrobianos na dieta pode ser atribuído ao seu efeito sobre a microbiota intestinal, atuando como agentes bactericidas ou bacteriostáticos, causando efeitos interativos com a fisiologia do animal (Muramatsu et al., 1994), como a economia de nutrientes, o efeito protetor contra a produção de toxinas no trato gastrintestinal, o efeito no controle de doenças subclínicas e o efeito metabólico (Menten, 1995).

Um dos modos de ação atribuído aos extratos vegetais na dieta pode ser o efeito antimicrobiano. Em um estudo in vitro, realizado por Dorman \& Deans (2000), os óleos 
essenciais de cravo, tomilho e orégano apresentaram pronunciado efeito antimicrobiano sobre determinados patógenos. O efeito antimicrobiano está relacionado, principalmente, com a alteração da permeabilidade e integridade da membrana celular bacteriana (Lambert et al., 2001). Existe uma relação entre a estrutura química dos compostos ativos presentes no extrato vegetal e seu efeito antimicrobiano (Farag et al., 1989), sendo que, geralmente, esse efeito pode ser atribuído à presença de compostos fenólicos (Dorman \& Deans, 2000). Alguns extratos vegetais apresentam alto poder antimicrobiano sobre diversos patógenos em estudos in vitro. Entretanto, o nível de inclusão para que esse efeito seja observado é, geralmente, elevado. Este pode ser um dos motivos pelo qual o tratamento com o maior nível de inclusão de extratos vegetais (2100 ppm) tenha apresentado melhores resultados de desempenho que os demais. Outro fator, discutido anteriormente, está relacionado com a melhora na digestibilidade aparente da matéria seca (Tabela 4). O aumento da digestibilidade de um nutriente contribui para um melhor aproveitamento do alimento pelo animal, resultando em melhor desempenho.

O modo de ação dos extratos vegetais em experimento in vivo não foi totalmente esclarecido e comprovado. Alguns trabalhos relatam resposta positiva do uso de extratos vegetais na dieta e outros não. Frangos alimentados com uma combinação de extratos vegetais apresentaram maior ganho de peso (625 vs 578 g/dia) e melhor conversão alimentar (1,44 vs 1,56) que os animais do tratamento controle (Jamroz \& Kamel, 2002). De acordo com os autores, a suplementação com extratos vegetais aumentou a digestibilidade dos nutrientes e favoreceu o equilíbrio da microbiota, diminuindo o potencial de adesão de patógenos ao epitélio intestinal. Em experimentos com leitões, a inclusão de 0,75\% de uma combinação de extratos vegetais na dieta promoveu maior ganho de peso em relação aos animais controle (26 vs -5 g/dia) na primeira semana pós-desmame, sendo que nos outros períodos não foram encontradas diferenças significativas (Jeaurond et al., 2002). Para suínos em fase de crescimento e terminação, o efeito benéfico da utilização de extrato(s) vegetal(is) na dieta geralmente está relacionado com a melhora na conversão alimentar. Confirmando essa hipótese, Lima et al. (2001) e Thaler et al. (2004) obtiveram respostas positivas sobre a eficiência alimentar de suínos nas fases de crescimento e terminação, suplementados com uma combinação de óleos essenciais e/ou ácidos orgânicos na dieta. Porém, nem sempre são encontradas diferenças significativas para o ganho de peso e o consumo de ração (Thaler et al., 2004). Da mesma forma, Kwon et al. (2004), utilizando um extrato vegetal à base de Artemisia capillaris, encontraram melhoras significativas na conversão alimentar à medida que aumentou de 0,02 a $0,06 \%$ o nível de inclusão desse extrato na dieta dos animais. Uma possível explicação para essa melhora da 
conversão alimentar pode estar relacionada com o fato de animais adultos apresentarem o sistema digestório mais desenvolvido no referente à produção enzimática e à morfo-histologia intestinal, e o efeito de estimulação da secreção pancreática, supostamente exercido pelos extratos vegetais (Sambaiah \& Srinivasan, 1991; Platel \& Srinivasan, 1996; Wang \& Bourne, 1998), seja mais pronunciado para essa categoria animal.

Em outros experimentos com frangos (Botsoglou et al., 2002b; Cross et al., 2003; Demir et al., 2003; Lee et al., 2003a, 2003b; Hernández et al., 2004), não foi possível observar diferença estatística no desempenho dos animais suplementados com diferentes tipos, concentrações e combinações de extratos vegetais na dieta. De acordo com Lee et al. (2003a), a ausência de efeito no desempenho dos animais pode estar relacionada com a composição da dieta basal utilizada e/ou condições ambientais a que foram submetidos os animais. Dietas altamente digestíveis limitam o desenvolvimento de bactérias no trato intestinal, pela redução de substrato disponível ao crescimento bacteriano, diminuindo, assim, o potencial antimicrobiano dos extratos vegetais. O mesmo pode acontecer, se os animais tiverem sido alojados em instalações com baixo desafio imunológico e rigoroso controle sanitário.

Em virtude das variações nas respostas encontradas na literatura, ainda não foi possível esclarecer o modo de ação dos extratos vegetais nas diferentes espécies animais. São necessários mais estudos para comprovar sua eficácia e determinar a melhor relação entre os diferentes tipos de extratos vegetais e suas concentrações na dieta para maximizar o desempenho dos animais e torná-los uma alternativa viável ao uso de antimicrobianos como promotores do crescimento.

\subsection{Morfometria dos órgãos}

A Tabela 8 apresenta as médias dos pesos relativos (em porcentagem do peso vivo no momento do abate) dos órgãos digestórios e não digestórios, assim como do comprimento, do comprimento relativo e da relação peso:comprimento do intestino delgado, em função dos tratamentos. Os Apêndices 8 e 9 apresentam os pesos absolutos dos órgãos e o peso vivo dos animais por unidade experimental. 
Tabela 8. Médias dos pesos relativos (porcentagem do peso vivo) dos órgãos digestórios e não digestórios, assim como do comprimento, do comprimento relativo e da relação peso:comprimento do intestino delgado, em função dos tratamentos

\begin{tabular}{|c|c|c|c|c|c|c|c|}
\hline \multirow[b]{2}{*}{ Órgão } & \multicolumn{5}{|c|}{ Tratamentos $^{1}$} & \multirow{2}{*}{$\operatorname{Pr}>\mathrm{F}$} & \multirow{2}{*}{$\begin{array}{c}\mathrm{CV}^{2} \\
(\%)\end{array}$} \\
\hline & $\mathrm{C}$ & A & $\mathrm{Ea}$ & Eb & Ec & & \\
\hline Trato gastrintestinal total (\%) ${ }^{3}$ & 20,77 & 18,75 & 20,01 & 21,13 & 20,67 & 0,0519 & 7,31 \\
\hline Estômago vazio (\%) & 0,818 & 0,717 & 0,819 & 0,767 & 0,780 & 0,1491 & 11,22 \\
\hline Pâncreas (\%) & 0,193 & 0,188 & 0,205 & 0,201 & 0,209 & 0,9144 & 20,86 \\
\hline Fígado (\%) & 2,679 & 2,719 & 2,909 & 2,853 & 2,953 & 0,5837 & 14,03 \\
\hline Vesícula biliar (\%) & 0,102 & 0,080 & 0,074 & 0,084 & 0,086 & 0,5090 & 37,66 \\
\hline Intestino delgado vazio (\%) ${ }^{4,5}$ & 4,349 & 3,927 & 4,579 & 4,828 & 4,768 & 0,0032 & 10,19 \\
\hline Intestino grosso vazio (\%) & 2,059 & 1,715 & 1,827 & 2,015 & 1,928 & 0,1624 & 15,61 \\
\hline Ceco vazio (\%) & 0,237 & 0,196 & 0,235 & 0,220 & 0,230 & 0,2042 & 16,83 \\
\hline Colo vazio (\%) & 1,822 & 1,519 & 1,395 & 1,795 & 1,697 & 0,0096 & 21,36 \\
\hline Pulmão (\%) & 1,343 & 1,413 & 1,366 & 1,398 & 1,306 & 0,9144 & 18,17 \\
\hline Coração (\%) & 0,497 & 0,556 & 0,530 & 0,551 & 0,522 & 0,4204 & 12,58 \\
\hline Rins (\%) & 0,561 & 0,581 & 0,554 & 0,556 & 0,587 & 0,6404 & 9,47 \\
\hline Baço (\%) & 0,202 & 0,262 & 0,224 & 0,235 & 0,221 & 0,1679 & 20,74 \\
\hline Comprimento ID (m) ${ }^{6}$ & 12,39 & 12,36 & 12,61 & 11,99 & 12,65 & 0,9432 & 13,85 \\
\hline Comp. relativo ID (m/kg PV) ${ }^{7}$ & 0,066 & 0,061 & 0,072 & 0,072 & 0,067 & 0,1106 & 12,95 \\
\hline Relação peso:comp ID (g/m) ${ }^{8}$ & 66,34 & 64,07 & 63,41 & 67,57 & 71,54 & 0,5340 & 15,35 \\
\hline
\end{tabular}

${ }^{1} \mathrm{C}=$ controle; $\mathrm{A}=$ antimicrobiano;Ea, Eb e Ec =700, 1400, 2100 ppm de extrato vegetal, respectivamente

${ }^{2}$ Coeficiente de variação

${ }^{3}$ Contrastes significativos: Controle x Antimicrobiano e Antimicrobiano x Extratos

${ }^{4}$ Contrastes significativos: Controle x Antimicrobiano, Controle x Extratos e Antimicrobiano x Extratos

${ }^{5}$ Efeito linear significativo para os níveis crescentes de extrato na dieta, onde $Y=0,150 x+4,255 ; R^{2}=0,81$

${ }^{6}$ Comprimento do intestino delgado

${ }^{7}$ Comprimento relativo do intestino delgado ( $\mathrm{m} / \mathrm{kg}$ de peso vivo no momento do abate)

${ }^{8}$ Relação peso:comprimento do intestino delgado

Foram encontradas diferenças significativas entre os tratamentos apenas para o peso relativo do trato gastrintestinal total e do intestino delgado vazio. As demais variáveis não sofreram efeitos significativos dos tratamentos. Os animais do tratamento com antimicrobiano apresentaram menor peso relativo do trato gastrintestinal total $(\mathrm{P}<0,05)$ que os animais do tratamento controle ou com diferentes níveis de extratos vegetais. Com relação ao peso relativo do intestino delgado vazio, o tratamento controle apresentou valores intermediários entre os demais tratamentos, sendo inferior $(\mathrm{P}<0,05)$ ao tratamento com extratos vegetais e superior $(\mathrm{P}<0,07)$ ao tratamento com antimicrobianos.

Os resultados encontrados estão de acordo com a literatura. Um dos modos de ação dos agentes antimicrobianos está relacionado com a redução na quantidade de 
microrganismos (produtores de toxinas) aderidos ao epitélio intestinal, e consequente redução da espessura da parede intestinal (Anderson et al., 1999). Tal fato proporciona uma economia de nutrientes por parte do animal para a manutenção dos tecido do trato gastrintestinal (Lima, 1999), favorecendo seu desempenho.

No presente estudo, nota-se que os animais que receberam extratos vegetais na dieta apresentaram, numericamente, maior peso relativo do pâncreas. Este resultado também foi encontrado em outros trabalhos, onde foram encontradas diferenças numéricas significativas (Lewis et al., 2004) ou não (Utiyama, 2004; Lee et al., 2003a) do peso relativo do pâncreas de animais que receberam extratos vegetais em relação ao tratamento controle. O aumento do pâncreas pode ser um indicativo de um estímulo da secreção pancreática e aumento da atividade enzimática. Confirmando essa hipótese, Lee et al. (2003a) observaram um aumento da atividade da amilase intestinal em relação ao tratamento controle (114 vs 111 unidades/g conteúdo intestinal) para frangos aos 21 dias de idade recebendo uma combinação de extratos vegetais (100 ppm) na dieta, contudo, aos 40 dias de idade, esse efeito não se manteve e o tratamento que proporcionou melhor resultado foi o tratamento à base de timol (princípio ativo do tomilho), sendo observado um aumento de $26 \%$ na atividade da tripsina intestinal. Com esses resultados, pode-se dizer que a sensibilidade das enzimas endógenas aos extratos vegetais pode ser modificada de acordo com a idade dos animais (Lee et al., 2003a).

O peso relativo do fígado é um outro dado que deve ser levado em consideração. Os animais que receberam extratos vegetais na dieta apresentaram, numericamente, maior peso relativo do fígado quando comparado ao tratamento controle (2,67 vs 2,90, 2,85 e 2,95\%, sendo Controle vs Ea, Eb e Ec, respectivamente). Embora não seja possível esclarecer o motivo desse aumento, vale ressaltar que, em outro experimento, frangos aos 21 dias de idade, recebendo 100 ppm de timol na dieta, também apresentaram aumento $(\mathrm{P}<0,05)$ no peso relativo do fígado em relação ao tratamento controle (2,59 vs 2,30 g/100g peso vivo) (Lee et al., 2003a).

\subsection{Histologia do epitélio intestinal}

A Tabela 9 apresenta as médias de altura das vilosidades ( $\mathrm{AV}, \mu \mathrm{m})$, de profundidade das criptas (PC, $\mu \mathrm{m})$ e da relação altura de vilosidade/profundidade de cripta (AV/PC) do duodeno, jejuno e íleo, em função dos tratamentos. 
Tabela 9. Médias de altura das vilosidades (AV, $\mu \mathrm{m})$, profundidade das criptas (PC, $\mu \mathrm{m}) \mathrm{e}$ relação altura de vilosidade/profundidade de cripta (AV/PC) do duodeno, jejuno e íleo, em função dos tratamentos

\begin{tabular}{|c|c|c|c|c|c|c|c|}
\hline & \multicolumn{5}{|c|}{ Tratamentos $^{1}$} & \multirow{2}{*}{$\operatorname{Pr}>F$} & \multirow{2}{*}{$\begin{array}{l}\mathrm{CV}^{2} \\
(\%)\end{array}$} \\
\hline & $\mathrm{C}$ & A & Ea & Eb & Ec & & \\
\hline \multicolumn{8}{|l|}{ Duodeno } \\
\hline $\operatorname{AV}(\mu \mathrm{m})$ & 266,04 & 238,18 & 261,55 & 245,80 & 249,21 & 0,9771 & 27,54 \\
\hline $\mathrm{PC}(\mu \mathrm{m})$ & 263,89 & 230,21 & 242,36 & 267,04 & 271,63 & 0,7731 & 20,95 \\
\hline $\mathrm{AV} / \mathrm{PC}$ & 1,100 & 1,132 & 1,202 & 1,062 & 1,080 & 0,9738 & 39,10 \\
\hline \multicolumn{8}{|l|}{ Jejuno } \\
\hline $\mathrm{AV}(\mu \mathrm{m})$ & 188,86 & 191,30 & 199,84 & 219,30 & 298,65 & 0,3850 & 39,10 \\
\hline $\mathrm{PC}(\mu \mathrm{m})$ & 278,40 & 277,39 & 311,71 & 228,72 & 246,15 & 0,1828 & 17,55 \\
\hline $\mathrm{AV} / \mathrm{PC}$ & 0,700 & 0,760 & 0,755 & 1,115 & 1,365 & 0,1665 & 44,16 \\
\hline \multicolumn{8}{|l|}{ Íleo } \\
\hline $\operatorname{AV}(\mu \mathrm{m})^{3}$ & 252,53 & 291,57 & 206,19 & 234,78 & 191,29 & 0,0413 & 17,98 \\
\hline $\mathrm{PC}(\mu \mathrm{m})$ & 215,34 & 217,55 & 233,71 & 213,73 & 230,25 & 0,7086 & 11,24 \\
\hline $\mathrm{AV} / \mathrm{PC}^{4,5}$ & 1,265 & 1,447 & 0,892 & 1,192 & 0,847 & 0,0079 & 18,77 \\
\hline
\end{tabular}

As Figuras 1 a 4 ilustram as vilosidades do epitélio intestinal, aos 35 dias de experimentação, a partir de imagens geradas por microscopia óptica e microscopia eletrônica de varredura. Por problemas na fixação das amostras no dia do abate, e posterior prejuízo na integridade das vilosidades, as eletronmicrografias de varredura não foram analisadas estatisticamente, possuindo, portanto, caráter ilustrativo. 

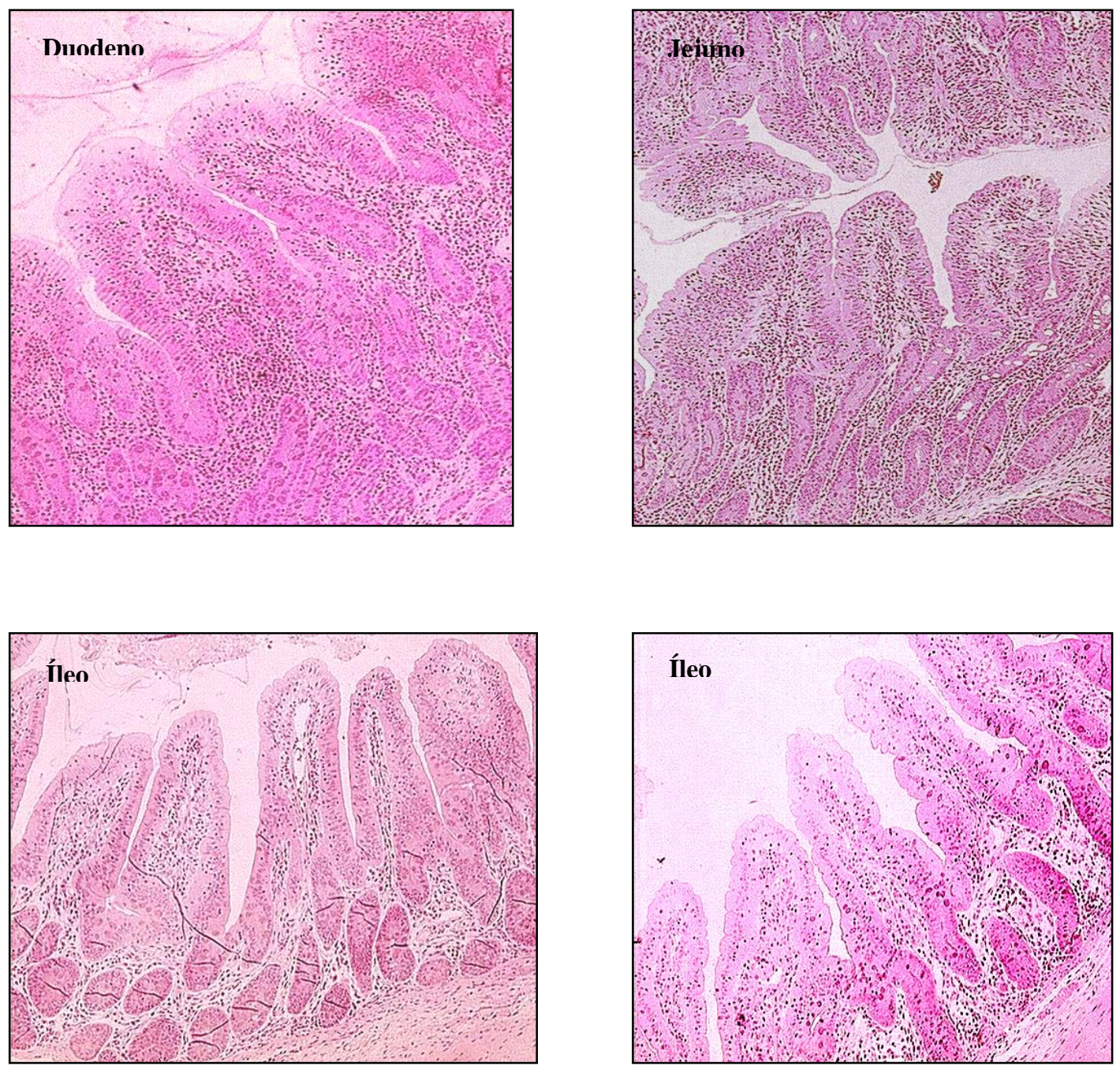

Figura 1 - Imagens das vilosidades do duodeno, jejuno e íleo feitas por microscopia óptica, aos 35 dias de experimentação 

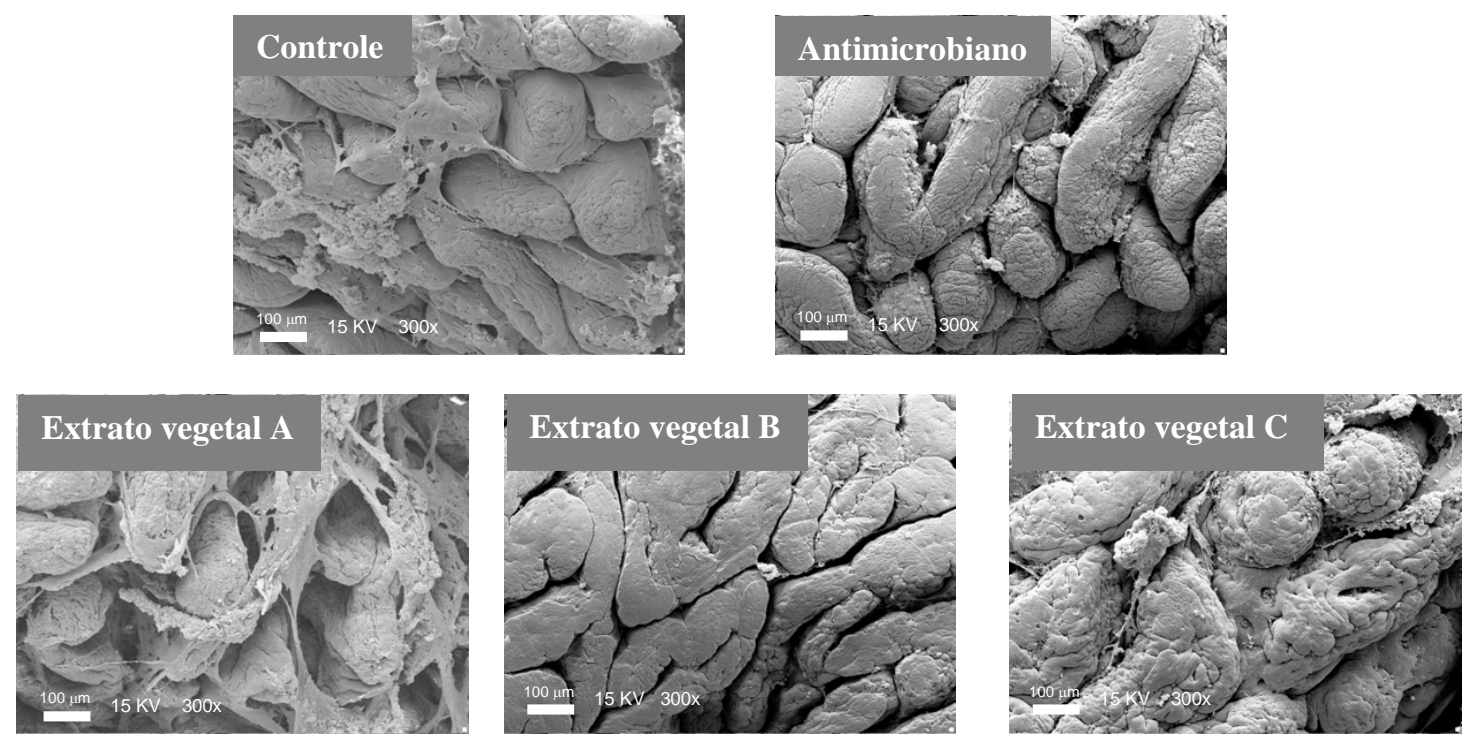

Figura 2 - Eletronmicrografias de varredura das vilosidades do duodeno dos leitões aos 35 dias de experimentação, de acordo com os tratamentos
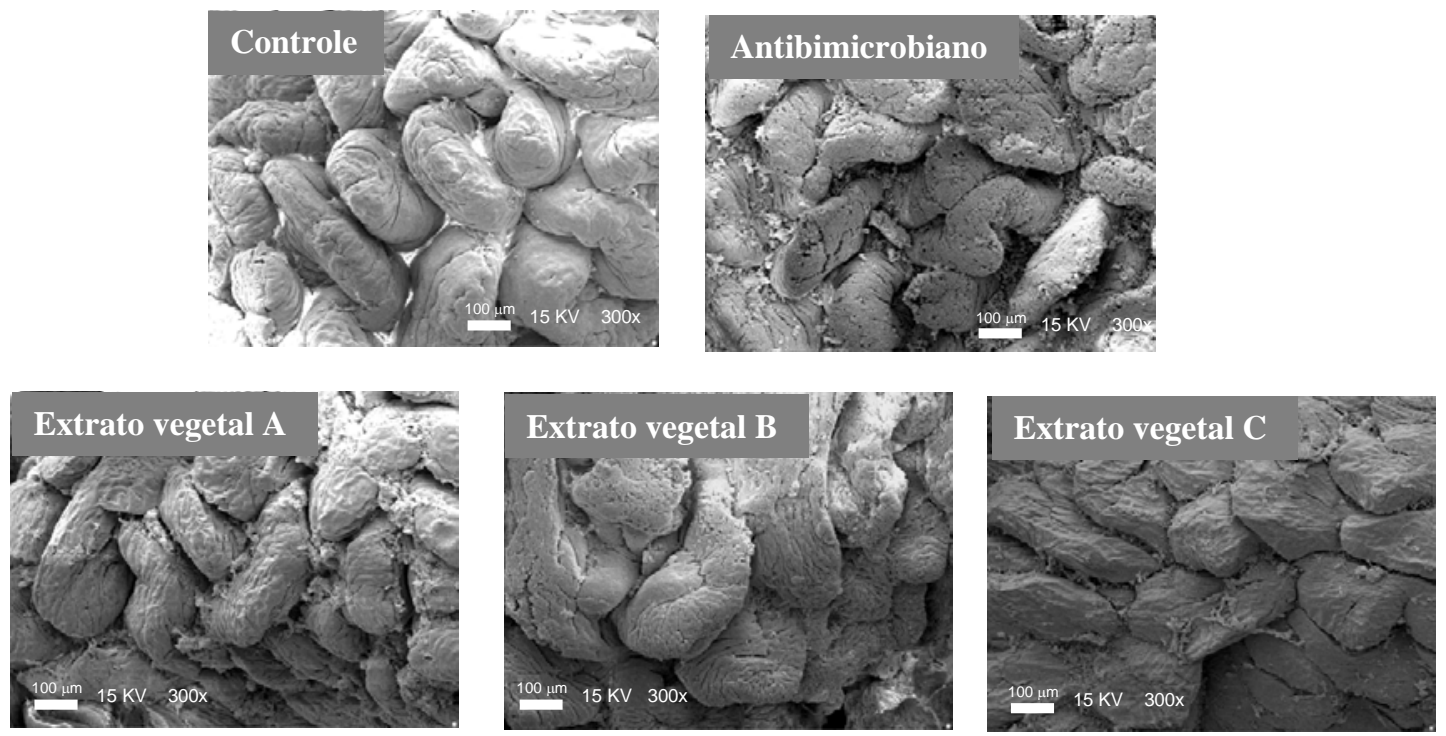

Figura 3 - Eletronmicrografias de varredura das vilosidades do jejuno dos leitões aos 35 dias de experimentação, de acordo com os tratamentos 

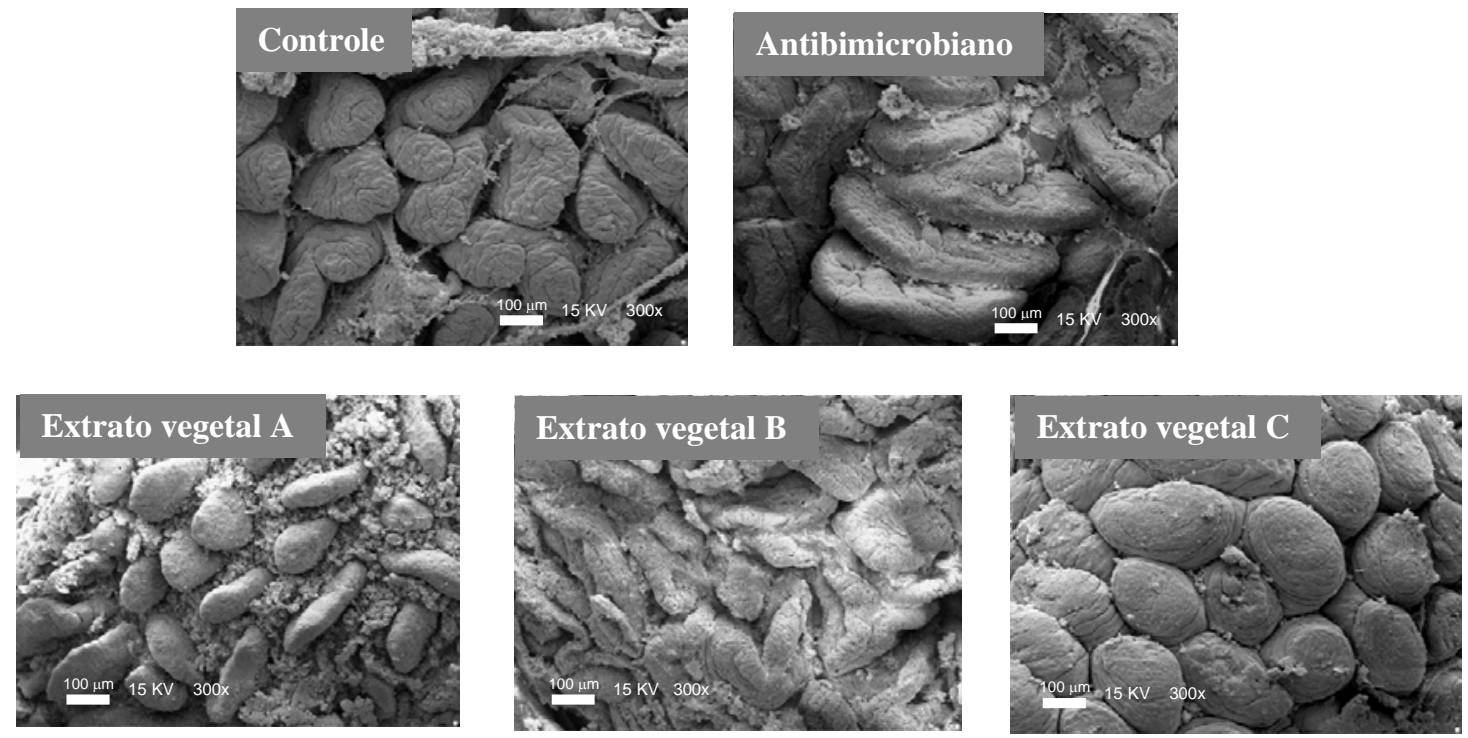

Figura 4 - Eletronmicrografias de varredura das vilosidades do íleo dos leitões aos 35 dias de experimentação, de acordo com os tratamentos

Houve diferenças entre os tratamentos $(\mathrm{P}<0,05)$ apenas para as variáveis altura de vilosidade do íleo e relação entre altura de vilosidade/profundidade de cripta do íleo. A maior altura de vilosidade foi obtida para o tratamento antimicrobiano em relação aos tratamentos com extratos vegetais. Para a relação altura de vilosidade/profundidade de cripta do íleo, os tratamentos com extratos vegetais diferiram $(\mathrm{P}<0,05)$ tanto do tratamento com antimicrobiano quanto do tratamento controle, tendo apresentado menores valores que ambos tratamentos.

No período pós-desmame, há, normalmente, atrofia das vilosidades em decorrência do aumento na taxa de descamação epitelial por consequência do início do consumo de ração sólida, do baixo consumo de ração, de toxinas bacterianas e da adesão de bactérias aos enterócitos (Cera et al., 1988). O aumento na descamação leva a um aumento na profundidade da cripta (Tucci, 2003) para assegurar a adequada taxa de renovação celular e garantir a reposição das perdas de células da região apical dos vilos (Pluske et al., 1997). Sendo assim, quanto maior a altura das vilosidades e menor a profundidade das criptas, melhor será a absorção de nutrientes e menor serão as perdas energéticas com o turnover celular.

Pelos resultados, não foi possível observar efeito significativo da utilização dos extratos vegetais sobre a histologia do epitélio intestinal. Contudo, nota-se que, no jejuno, maiores níveis de inclusão de extrato vegetal apresentaram maior altura de vilosidade e menor profundidade de cripta que os demais tratamentos. Esses resultados indicam que, possivelmente, 
haja uma ação específica do extrato vegetal sobre determinada área do intestino delgado. Existem outros trabalhos na literatura onde são observadas melhorias na histologia do epitélio intestinal, com a utilização de extratos vegetais na dieta. Demir et al. (2003) observaram uma redução $(\mathrm{P}<0,05)$ na profundidade da cripta de frangos que receberam tomilho na dieta em relação ao tratamento controle (157,8 vs 181,3 $\mu \mathrm{m})$. Em leitões, embora os resultados também não tenham mostrado diferenças significativas, o tratamento com extratos vegetais (500 ppm) também trouxe efeitos benéficos ao epitélio intestinal, aumentando a altura das vilosidades e a relação entre altura de vilosidade/profundidade de cripta tanto no duodeno quanto no jejuno (Utiyama, 2004).

Em virtude do reduzido número de trabalhos com suínos, avaliando os efeitos de extratos vegetais sobre a histologia do epitélio intestinal, não é possível esclarecer e comprovar o efeito dos extratos vegetais sobre essa variável.

\subsection{Microbiologia intestinal}

Os resultados obtidos nas análises microbiológicas são apresentados na Tabela 10. Os resultados para Staphylococcus spp. foram menores que 10 Unidades Formadoras de Colônias (UFC) para todas amostras. Em relação ao Campylobacter coli, somente dois animais, pertencentes aos tratamentos Ea e Ec, apresentaram resultado positivo (100 UFC/g). Por isso, esses dados não constam na tabela abaixo.

Tabela 10. Médias das contagens de microrganismos (log UFC/g de conteúdo do intestino delgado) de leitões, em função dos tratamentos

\begin{tabular}{|c|c|c|c|c|c|c|c|}
\hline \multirow{2}{*}{ Microrganismos } & \multicolumn{5}{|c|}{ Tratamentos $^{1}$} & \multirow{2}{*}{$\operatorname{Pr}>F$} & \multirow{2}{*}{$\begin{array}{l}\mathrm{CV}^{2} \\
(\%)\end{array}$} \\
\hline & $\mathrm{C}$ & $\mathrm{A}$ & $\mathrm{Ea}$ & $\mathrm{Eb}$ & Ec & & \\
\hline Totais & 6,151 & 7,581 & 6,631 & 6,431 & 6,800 & 0,56 & 18,22 \\
\hline Gram positivos & 6,151 & 7,526 & 6,610 & 6,238 & 6,756 & 0,57 & 18,74 \\
\hline Gram negativos & 0 & 3,248 & 0,636 & 4,888 & 2,898 & 0,14 & 118,81 \\
\hline Bacillus spp. & 1,448 & 3,484 & 2,374 & 5,908 & 2,898 & 0,30 & 89,66 \\
\hline Streptococcus spp. & 2,876 & 3,969 & 2,804 & 3,165 & 3,560 & 0,89 & 57,63 \\
\hline Escherichia coli & 3,729 & 5,210 & 3,942 & 4,255 & 3,853 & 0,43 & 28,13 \\
\hline Clostridium perfringens & 3,262 & 3,549 & 3,928 & 4,317 & 3,829 & 0,39 & 19,98 \\
\hline
\end{tabular}


Não houve diferença $(\mathrm{P}>0,05)$ entre os tratamentos para nenhum dos microrganismos analisados. Entretanto, é possível notar que o tratamento controle não apresentou contagem de microrganismos gram negativos para nenhuma das quatro repetições. Uma das explicações para esse fato pode ser em decorrência de falhas na metodologia de coleta e análise dos dados, assim como possíveis variações na microbiota intestinal.

A coleta das amostras foi realizada através da raspagem de todo segmento do intestino delgado, sem diferenciar os segmentos do duodeno, jejuno e íleo. Entretanto, sabe-se que a composição bacteriana ao longo do intestino delgado pode apresentar grandes variações (Pedroso et al., 2005), e isso pode ter influenciado os resultados encontrados.

Um dos maiores pré-requisitos para estudar os efeitos de certos componentes sobre a microbiota animal baseia-se na quantificação correta dos diferentes grupos de bactérias. O método de plaqueamento é o mais utilizado em estudos com animais. Entretanto, alguns autores têm questionado a eficácia dessa técnica na avaliação da composição, estrutura e estabilidade de um ecossistema intestinal, principalmente em decorrência de suas limitações fisiológicas, como meios de cultura seletivos, redução no número de bactérias durante o processo e ambiente inadequado ao crescimento de todas bactérias (Simpson et al., 1999).

A população microbiana está em constante modificação de seu equilíbrio natural. As variedades, quantidades e distribuição das bactérias no trato gastrintestinal são sensíveis a variações mínimas do estado fisiológico do animal (mudanças no $\mathrm{pH}$, secreções enzimáticas, biliares, etc.), interações microbianas (tanto sinergismo quanto antagonismo) e composição da dieta (Holzapfel et al., 1998). Portanto, qualquer tipo de alteração fisiológica e/ou estresse sofrido pelos animais também pode ter influenciado os resultados e alterado a composição da microbiota intestinal no momento da coleta das amostras.

Para a maioria dos microrganismos analisados, o tratamento com antimicrobiano apresentou os maiores valores numéricos em relação aos demais tratamentos. Isso pode ser um indicativo de que os antimicrobianos atuem na modificação da microbiota e não na redução do número de microrganismos. Alterações na microbiota intestinal foram confirmadas por Pedroso et al. (2005), onde os animais que receberam antimicrobianos apresentaram um perfil diferenciado de bactérias no trato gastrintestinal em relação ao tratamento controle. Uma outra hipótese é o fato de a diarréia poder causar diminuição no número de genótipos bacterianos em diferentes segmentos do trato intestinal de suínos. Talvez este fato possa explicar a menor contagem de microrganismos encontrada para o tratamento controle. 


\subsection{Frequência de diarréia}

As porcentagens médias de ocorrência de diarréias, assim como as médias transformadas pela função $y=\operatorname{arcsen} \sqrt{(p / 100)}$ estão apresentadas na Tabela 11, para os períodos de 1 a 14 e 1 a 35 dias de experimentação. A transformação dos dados foi necessária para efetuar a análise estatística. Nos Apêndices 10 e 11 estão as médias por baia da frequência de diarréia (porcentagem de dias com diarréia) para todos experimentos, antes da transformação dos dados.

Tabela 11. Médias de frequência de diarréia (MFD, \%) e média transformada (MT) para os períodos de 1 a 14 e 1 a 35 dias de experimentação

\begin{tabular}{ccccc}
\hline & \multicolumn{3}{c}{ Período } \\
Tratamento $^{1}$ & \multicolumn{2}{c}{1 a 14 dias } & \multicolumn{2}{c}{1 a 35 dias $^{2}$} \\
& MFD (\%) & MT & MFD (\%) & MT \\
\hline C & 23,55 & 0,41 & 28,31 & 0,51 \\
A & 15,99 & 0,31 & 13,30 & 0,30 \\
Ea & 19,26 & 0,49 & 22,35 & 0,48 \\
Eb & 14,20 & 0,36 & 17,47 & 0,41 \\
Ec & 18,96 & 0,46 & 19,37 & 0,47 \\
Pr $>$ F & --- & 0,0902 & --- & 0,0084 \\
CV (\%) & --- & 41,56 & --- & 32,92 \\
\hline
\end{tabular}

${ }^{1} \mathrm{C}=$ controle; $\mathrm{A}=$ antimicrobiano;Ea, Eb e Ec =700, 1400, 2100 ppm de extrato vegetal, respectivamente

${ }^{2}$ Contrastes significativos: Controle x Antimicrobiano e Antimicrobiano x Extratos

${ }^{3}$ Coeficiente de variação

Foram observadas diferenças $(\mathrm{P}<0,05)$ entre os tratamentos para frequência de diarréia no período de 1 a 35 dias de experimentação. Os animais suplementados com antimicrobianos apresentaram menor frequência de diarréia $(\mathrm{P}<0,05)$ que os do tratamento controle ou com extratos vegetais. Pelos valores numéricos, nota-se que os animais que receberam extratos vegetais na dieta apresentaram menor frequência de diarréia em relação ao tratamento controle no período de 1 a 35 dias de experimentação.

A diarréia pós-desmame pode ser causada principalmente pela colonização da superfície epitelial por patógenos, tais como a Escherichia coli enterotoxigênica, Salmonella typhimurium, e Clostridium spp. (Stewart \& Chesson, 1993) e pela presença de resíduos alimentares não digeridos e não absorvidos, que servem como substratos para os microrganismos patogênicos. Os resíduos de alimentos, juntamente com íons minerais (sódio, potássio e cloro) 
presentes no epitélio intestinal, contribuem para o aumento da osmolaridade do conteúdo intestinal, dificultando o processo de reabsorção de água e desencadeando a diarréia (Etheridge et al., 1984; Nabuurs et al., 1993).

Um dos efeitos dos antimicrobianos sobre o organismo animal está relacionado com a redução da população microbiana, diminuindo a fermentação de carboidratos e a incidência de diarréia (Anderson et al., 1999). Apesar das análises microbiológicas não terem acusado uma redução da contagem de microrganismos para o tratamento antimicrobiano, nota-se que a frequência de diarréia dos animais suplementados com antimicrobianos foi inferior a do controle em todos os períodos considerados. Portanto, pode-se dizer que os antimicrobianos foram eficientes no controle da diarréia, mesmo não tendo apresentado redução no número de microrganismos analisados.

Como descrito anteriormente, um dos modos de ação atribuído aos extratos vegetais na dieta pode ser o efeito antimicrobiano. Esta também pode ser uma das explicações para que o tratamento com extratos vegetais tenha apresentado menores valores numéricos de frequência de diarréia no período de 1 a 35 dias de experimentação em relação ao tratamento controle. 


\section{CONCLUSÕES}

Os agentes antimicrobianos melhoraram o peso vivo, consumo diário de ração e ganho diário de peso em todos períodos analisados. Dentre os níveis de extratos vegetais, o maior nível de inclusão foi o que proporcionou melhores resultados de desempenho. A utilização de extratos vegetais na dieta de leitões recém-desmamados não alterou a morfometria dos órgãos e nem a histologia do epitélio intestinal, mas aumentou a digestibilidade aparente da matéria seca.

Os antimicrobianos e extratos vegetais não alteraram a microbiota intestinal dos leitões. Contudo, os antimicrobianos reduziram a frequência de diarréia no período de 1 a 35 dias de experimentação e os extratos vegetais apresentaram resultados intermediários entre o tratamento controle e com antimicrobianos. 


\section{REFERÊNCIAS BIBLIOGRÁFICAS}

AHMAD, I.; MEHMOOD, Z.; MOHAMMAD, F. Screening of some Indian medicinal plants for their antimicrobial properties. Journal of Ethnopharmacology, v.62, p.183-193, 1998.

ALÇIÇEK, A.; BOZKURT, M.; ÇABUK, M. The effect of a mixture of herbal essential oils, an organic acid or a probiotic on broiler performance. South African Journal of Animal Science, v.34, n.4, p.217-222, 2004.

ANDERSON, D.B.; McCRACKEN, V.J.; AMINOV, R.I. et al. Gut microbiology and growth-promoting antibiotics in swine. Pig News Information, v.20, p.115-122, 1999.

ARAÚJO, C.A.C.; LEON, L.L. Biological activities of Curcuma longa L. Memorandos do Instituto Oswaldo Cruz, v.96, p.723-728, 2001.

ASSOCIATION OF OFFICIAL ANALYTICAL CHEMISTS. Official methods of analysis. 13.ed. Washington, 1980. 1025p.

BARBIN, D. Planejamento e análise estatística de experimentos agropecuários. Arapongas: Midas, 2003. 194p.

BAYNES, P.; VARLEY, M. Gut health: practical considerations. In: VARLEY, M.A.; WISEMAN, J. (Ed.). The weaner pig: nutrition and management. Nothingham: CABI Publishing, 2001. cap.12, p. 249-257.

BOTSOGLOU, N.A.; FLOROU-PANERI, P.; CHRISTAKI, E. et al. Performance of rabbits and oxidative stability of muscle tissues as affected by dietary supplementation with oregano essential oil. Archives of Animal Nutrition, v.58, n.3, p.209-218, 2004. 
BOTSOGLOU, N.A.; FLETOURIS, D.J.; FLOROU-PANERI, P. et al. Inhibition of lipid oxidation in long-term frozen stored chicken meat by dietary oregano essential oil and $\alpha$-tocopheryl acetate supplementation. Food Research International, v.36, p.207-213, 2003a.

BOTSOGLOU, N.A.; GOVARIS, A.; BOTSOGLOU E.N. et al. Antioxidant activity of dietary oregano essential oil and r-tocopheryl acetate supplementation in long-term frozen stored turkey meat. Journal of Agricultural and Food Chemistry, v.51, p.2930-2936, 2003b.

BOTSOGLOU, N.A.; CHRISTAKI, E.; FLETOURIS, D.J. et al. The effect of dietary oregano essential oil on lipid oxidation in raw and cooked chicken during refrigerated storage. Meat Science, v.62, p.259-265, 2002a.

BOTSOGLOU, N.A.; FLOROU-PANERI, P.; CHRISTAKI, E. et al. Effect of dietary oregano essential oil on performance of chickens and on iron-induced lipid oxidation of breast, thigh and abdominal fat tissues. British Poultry Science, v.43, p.223-230, 2002b.

BRUGALLI, I. Alimentação alternativa: a utilização de fitoterápicos ou nutracêuticos como moduladores da imunidade e desempenho animal. In: SIMPÓSIO SOBRE MANEJO E NUTRIÇÃO DE AVES E SUÍNOS, Campinas, 2003. Anais. Campinas: CBNA, 2003. p.167-182.

BURT, S. Essential oils: their antibacterial properties and potencial applications in foods - a review. International Journal of Food Microbiology, v.94, p.223-253, 2004.

BURT, S.A.; REINDERS, R.D. Antibacterial activity of selected plant essential oils against Escherichia coli 0157:H7. Letters in Applied Microbiology, v.36, p.162-167, 2003.

BUTOLO, J.E. Uso de aditivos na alimentação de aves: frangos de corte. In: SIMPÓSIO SOBRE AS IMPLICAÇÕES SÓCIO-ECONÔMICAS DO USO DE ADITIVOS NA PRODUÇÃO ANIMAL, Piracicaba, 1999. Anais. Piracicaba: CBNA, 1999. p.85-98.

CAMPABADAL, C.; VARGAS, E.; FONSECA, M. Evaluación de los ácidos orgánicos en la alimentación de lechones. I. Uso del ácido cítrico. Agronomía Costarricense, v.19, p.47-51, 1995.

CERA, K.R.; MAHAN, D.C.; CROSS, R.F. et al. Effect of age, weaning and postweaning diet on small intestinal growth and jejunal morphology in young swine. Journal of Animal Science, v.66, p.574$584,1988$.

CICHEWICZ, R. H.; THORPE, P. A. The antimicrobial properties of chile peppers (Capsicum species) and their uses in Mayan medicine. Journal of Ethnopharmacology, v.42, p.61-70, 1996. 
COATES, M.E.; DAVIES, M.K.; KON, S.K. The effect of antibiotics on the intestine of the chick. British Journal of Nutrition, v.9, p.110-119, 1955.

CROSS, D.E.; SVOBODA, K.; McDEVITT, R.M. et al. The performance of chickens fed diets with and without thyme oil and enzymes. British Poultry Science, v.44, p.S18-S19, 2003.

DEMIR, E.; SARICA, S.; ÖZCAN, M.A. et al. The use of natural feed additives as alternative for an antibiotic growth promotres in broiler diets. British Poultry Science, v.44, p.44-45, 2003.

DORMAN, H.J.D.; DEANS, S.G. Antimicrobial agents from plants: antibacterial activity of plant volatile oil. Journal of Applied Microbiology, v.83, p.308-316, 2000.

EISSER, H.; SOMER, P. Effect of Streptococcus faecalis and a filterable agent on growth and nutrient absortion in gnotobiotic chicks. Poultry Science, v.42, p.1373-1379, 1966.

ESSAWI, T.; SROUR, M. Screening of some Palestinian medicinal plants for antibacterial activity. Journal of Ethnopharmacology, v.70, p.343-349, 2000.

ETHERIDGE, R.D.; SEERLEY, R.W.; WYATT, R.D. The effect of the diet on performance, digestibility, blood composition and intestinal microflora of weaned pigs. Journal of Animal Science, v.58, p.1396-1402, 1984.

FAO. http://apps.fao.org/page/collections?subset=agriculture (16 fev. 2004).

FARAG, R.S.; DAW, Z.Y.; HEWEDI, F.M. et al. Antimicrobial activity of some Egyptian spice essential oils. Journal of Food Protection, v.52, n.9, p.665-667, 1989.

FREITAS, R. O alho (Allium sativum) como estimulante do crescimento de frangos de corte em comparação com promotores de crescimento usados na indústria de rações. Viçosa, 1992. 60p. Dissertação (Mestrado) - Universidade Federal de Viçosa.

GANESH-BAHT, B.; SRINIVASAN, M.R.; CHANDRAEKHARA, N. Influence of curcumin and capsaicin on the composition and secretion of bile in rats. Journal of Food Science and Technology, v.21, p.225-227, 1984.

GEARY, T.M.; BROOKS, P.H.; BEAL, J.D. et al. Effect on weaner pig performance and diet microbiology of feeding a liquid diet acidified to $\mathrm{pH} 4$ with either lactic or through fermentation with Pediococcus acidilactici Journal of the Science of Food and Agriculture, v.79, p.633-640, 1999. 
GUARRERA, P.M. Tradicional antihelmintic, atiparasitic and repellent uses of plants in Central Italy. Journal of Ethnopharmacology, v.68, p.183-192, 1999.

GUPTA, A.; SANDHU, R.S. Effect of garlic agglutinin and garlic extracts on the rat jejunun. Nutrition Research, v.18, p.841-850, 1998.

HARRIS, J.C.; COTTREL, S.L.; PLUMMER, S. et al. Antimicrobial properties of Allium sativum (garlic). Applied Microbiology Biotechnology, v.57, p.282-286, 2001.

HENRY, P., AMMERMAN, C.B., CAMPBELL, D.R., et al. Effect of antibiotics on tissue trace mineral concentration and intestinal tract weight of broiler chicks. Poultry Science, v.66, p.1014-1018, 1987.

HERNÁNDEZ, F.; MADRID, J.; GARCÍA, V. et al. Influence of two plant extracts on broilers performance, digestibility, and digestive organ size. Poultry Science, v.83, p.169-174, 2004.

HOLZPAFEL, W.H.; HABERER, P.; SNEL, J. et al. Overview of gut flora and probiotics. International Journal of Food Microbiology, v.41, p.85-101, 1998.

HRAS, A.R.; HADOLIN, M.; KNEZ, Z. et al. Comparison of antioxidative ans synergistic effects of Rosemary extract with $\alpha$-tocopherol, ascorbyl palmitate and citric acid in sunflower oil. Food Chemistry, v. 71, p.229-233, 2000.

HUI, Y.H. Oleoresins and essential oils. In: HUI, Y.H. (Ed.). Bailey's industrial oil and fat products, New York, USA: Wiley-Interscience Publication, 1996. cap.6, 145-153.

HUYGHEBAERT, G. Replacement of antibiotics in poultry. In: EASTERN NUTRITION CONFERENCE, 2003, Quebec City. Anais. Quebec City: UON, 2003. p.1-23.

JAMROZ, D.; KAMEL, C. Plant extracts enhance broiler performance. Journal of Animal Science, v.80, p.41, suppl.1, 2002.

JEAUROUND, E.; SCHUMANN, B.; CLUNIES, M. et al. Supplementation of diets with herbal extracts enhances growth performance in newly-weaned piglets. Journal of Animal Science, v.80, p.394, suppl. 1, 2002.

JIN, L.Z.; HO, Y.W.; ZHAO, X. Probiotics in poultry: modes of action. World's Poultry Science Journal, v.53, p.351-368, 1997. 
JIN, L.; REINOLDS, L.P.; REDNER, D.A.; CATON, J.S.; CRENSHAW, J.D. Effects of dietary fiber on intestinal growth, cell proliferation, and morphology in growing pigs. Journal of Animal Science, v.72, p.2270-2278, 1994.

JONES, G. P. High-performing livestock and consumer protection are not contradictory. Feed Magazine, v.12, 2001.

JONES, G. Phytobiotic solutions. Pig Progress, v.18, n.8, 2002.

JONG, E.U., LEBOUTE, E.M., CIOCCA, M.L., et al. Uso de avoparcina e virginiamicina como promotores de crescimento em rações de frangos de corte. 2. Efeito sobre a flora intestinal e estrutura física do intestino. Revista da Sociedade Brasileira de Zootecnia, v.14, p.536-542, 1985.

KALEMBA, D.; KUNICKA, A. Antibacterial and antifungal properties of essential oils. Current Medicinal Chemistry, v.10, p.813-829, 2003.

KAMEL, C. A novel look at a classic approach of plant extracts. Feed Mix, v.9, n.6, p.19-24, 2000. Número especial.

KARANIKA, M.S.; KOMAITIS, M.; AGGELIS, G. Effect of aqueous extract of some plants of Lamiaceae family on the growth of Yarrowia lipolytica. International Journal of Food Microbiology, v.64, p.175-181, 2001.

KELLY, D.; KING, T.P. Digestive physiology and development in pigs. In: VARLEY, M.A.; WISEMAN, J. (Ed.). The weaner pig: nutrition and management. Nothingham, UK: CABI Publishing, 2001. cap.9, p. 179-206.

KOHLERT, C; VAN RENSEN, I.; MARZ, R. et al. Bioavailability and pharmokinetics of natural volatile terpenes in animal and humans. Planta Medica, v.66, p.495-505, 2000.

KRAUSE, D.O; WHITE, B.A.; MACKIE, R.I. Ribotyping of adherent Lactobacillus from weaning pigs: a basis for probiotic selection based on diet and gut compartment. Anaerobe, v.3, n.5, p.317-325, 1997.

KWON, S.; MIN, B.J.; LEE, W.B. et al. Effect of dietary natural herb extract (Biomate) supplementation on growth performance, IGF-1 and carcass characteristics in growing-finishing pigs. Journal of Animal Science, v.82, suppl. 1, p.177, 2004. 
LAMBERT, R.J.W.; SKANDAMIS, P.N.; COOTE, P.J. et al. A study of the minimum inhibitory concentration and mode of action of oregano essential oil, thymol and carvacrol. Journal of Applied Microbiology, v.91, p.453-462, 2001.

LANGHOUT, P. New additives for broiler chickens. Feed Mix, v.18, n.6, p.24-27, 2000. Número especial.

LEE, K-G; SHIBAMOTO, T. Determination of antioxidant potential of volatile extractsisolated from various herbs and spices. Journal of Agricultural and Food Chemistry, v.50, p.4947-4952, 2002.

LEE, K.W.; EVERTS, H.; KAPPERT, H.J. et al. Effects of dietary essential oil components on growth performance, digestive enzymes and lipid metabolism in female broiler chickens. British Poultry Science, v.44, n.3, p.450-457, 2003a.

LEE, K.W.; EVERTS, H.; KAPPERT, H.J. et al. Dietary carvacrol lowers body weight but improves feed conversion in female broiler chickens. Journal of Applied Poultry Research, v.12, p.394-399, 2003b.

LEWIS, M.R.; ROSE, S.P.; MACKENZIE, A.M. et al. The effects of dietary herbal extracts for broiler chickens. Journal of Animal Science, v.82, suppl. 1, p.169, 2004.

LIMA, G.J.M.M. Uso de aditivos na produção de suínos. In: SIMPÓSIO SOBRE AS IMPLICAÇÕES SÓCIO-ECONÔMICAS DO USO DE ADITIVOS NA PRODUÇÃO ANIMAL, Piracicaba, 1999. Anais. Piracicaba: CBNA, 1999. p.51-68.

LIMA, G.J.M.M.; RUTZ, F.; BORGES, S.A. et al. Efeito da adição de um composto de ervas naturais como promotor de crescimento de dietas de suínos em crescimento e terminação. In: CONGRESSO BRASILEIRO DE VETERINÁRIOS ESPECIALISTAS EM SUÍNOS, 10., Foz do Iguaçu, 2001. Resumos. Foz do Iguaçu: ABRAVES, 2001. p. 323-324.

LODDI, M.M., SATO, R.N., ARIKI, J. et al. Ação isolada ou combinada de antibiótico ou probiótico como promotores de crescimento em rações iniciais de frangos de corte. In: REUNIÃO DA SOCIEDADE BRASILEIRA DE ZOOTECNIA, 37, Viçosa, 2000. Anais. Viçosa: UFV, 2000. p.254.

LOPEZ-BOTE, C.J.; GRAY, J.K.; GOMAA, E.A. et al. Effect of dietary administration of oil extracts from rosemary and sage on lipid oxidation in broiler meat. British Poultry Science, v.39, p.235-240, 1998. 
MADEIRA, H.M.F. Uso de aditivos na alimentação de bovinos. In: SIMPÓSIO SOBRE AS IMPLICAÇÕES SÓCIO-ECONÔMICAS DO USO DE ADITIVOS NA PRODUÇÃO ANIMAL, Piracicaba, 1999. Anais. Piracicaba: UNIMEP, 1999, p.69-84.

MADSEN, H.L.; BERTELSEN, G. Spices as antioxidants. Trends in Food Science and Technology, v.6, p.271-277, 1995.

MADSEN, H.L.; BERTELSEN, G.; SKIBSTED, L.H. Antioxidative activity of spices and spice extracts. In: RISCH, S.J.; HO, S.C.T. (Ed.). Spices, flavor, chemistry and antioxidant properties. Washington, USA: American Chemical Society, 1997. cap.14, p.176-187.

MAHASNEH, A.M.; EL-OQLAH, A.A. Antimicrobial activity of extracts of herbal plants used in the traditional medicine of Jordan. Journal of Ethnopharmacology, v.64, p.271-276, 1999.

MAHMOUD, A.L.E. Antifungal action and antiaflatoxigenic properties of some essential oils constituents. Letters in Applied Microbiology, v.19, p.110-113, 1994.

MAHROUR, A.; LACROIX, M.; NKETSA-TABIRI, J. et al. Antimicrobial properties of natural substances in irradiated fresh poultry. Radiation Physics Chemistry, v.52, p.81-84, 1998.

MARTINEZ, M.J.; BETANCOURT, J.; ALONSO-GONZÁLEZ, N. et al. Screening of some Cuban medicinal plants for antimicrobial activity. Journal of Ethnopharmacology, v.52, p.171-174, 1996.

MARTINS, E.R.; CASTRO, D.M.; CASTELLANI, D.C. et al. Plantas Medicinais. Viçosa, MG: UFV, 2000. 220p.

MANZANILLA, E.G.; PEREZ, J.F. MARTIN, M. et al. Effect of plant extract and formic acid on the intestinal equilibrium of early-weaned pigs. Journal of Animal Science, v.82, p.3210-3218, 2004.

McCRACKEN, B.A.; SPURLOCK, M.E.; ROOS, M.A. et al. Weaning anorexia may contribute to local inflammation in the piglet small intestine. Journal of Animal Nutrition, v.129, p.613-619, 1999.

MELLOR, S. Alternatives to antibiotic. Pig Progress, v.16, p.18-21, 2000.

MENTEN, J.F.M. Eficácia, efeito sinérgico e modo de ação de agentes antimicrobianos como promotores do crescimento de suínos. Piracicaba, 1995. 106p. Tese (Livre Docência) - Escola Superior de Agricultura “Luiz de Queiroz”, Universidade de São Paulo. 
MENTEN, J.F.M. Aditivos alternativos na produção de aves: probióticos e prebióticos. In: REUNIÃO ANUAL DA SOCIEDADE BRASILEIRA DE ZOOTECNIA, 38, Piracicaba, 2001. Anais. Piracicaba: FEALQ, 2001. p.141-157.

MENTEN. J.F.M. Probióticos, prebióticos e aditivos fitogênicos na nutrição de aves. In: SINPÓSIO SOBRE INGREDIENTES NA ALIMENTAÇÃO ANIMAL, 2, Campinas, 2002. Anais. Campinas:Colégio Brasileiro de Nutrição Animal, 2002. p.251-276.

MILOS, M.; MASTELIC, J.; JERKOVIC, I. Chemical composition and antioxidant effect of glycosidically bound volatile compounds from oregano (Origanun vulgare L. ssp. hirtum). Food Chemistry, v.71, p.79-83, 2000.

MILTEMBERG, G. Extratos herbais como substitutos de antimicrobianos na alimentação animal. In: SIMPÓSIO SOBRE ADITIVOS ALTERNATIVOS NA NUTRIÇÃO ANIMAL, Campinas, 2000. Anais. Campinas: IAC, 2000. p.87-100.

MOLLER, J.K.S.; MADSEN, H.L.; AALTONEN, T. et al. Dittany (Origanum dictamnus) as a source of water-extractable antioxidants. Food Chemistry, v.64, p.215-219, 1999.

MURAMATSU, T.; NAKAJIMA, S.; OKUMURA, J. Modification of the energy metabolism by preence of the gut microflora in the chiken. British Journal of Nutrition, v.71, p.709-717, 1994.

NABUURS, M.J.A; ZIJDERVELD, F.G.; DE LEEUW, P.W. Villus height and crypt depth in weaned and unweaned pigs, reared under various circumstances in the Netherlands. Research in Veterinary Science, v.55, p-78-84, 1993.

NASCIMENTO, G.G.F.; LOCATELLI, J.; FREITAS, P.C. et al. Antibacterial activity of plant extracts and phytochemicals on antibiotic resistant bacteria. Brazilian Journal of Microbiology, v.31, p.247256, 2000.

NASCIMENTO FILHO, V.F.; ABDALA, A.L.; KORNDORFER, C.M. et al. Sensibilidades analíticas de diferentes modos de excitação em fluorescência de raios $\mathrm{X}$ para medida de traçadores em fezes de animais. In: ENCONTRO CIENTÍFICO DOS PÓS GRADUANDOS DO CENA/USP, Piracicaba, 1997. Resumos. Piracicaba: CENA, 1997. p.69.

NAVARRO, V.; DELGADO, G. Two antimicrobial alkaloids from Bocconia arborea. Journal of Ethnopharmacology, v.65, p.223-226, 1999. 
OUATTARA, B.; SIMARD, R.E.; HOLLEY, R.A. et al. Antibacterial activity of selected fatty acids and essential oils against six meat spoilage organisms. International Journal of Food Microbiology, v.37, p.155-162, 1997.

PAPAGEORGIOU, G.; BOTSOGLOU, N.; GOVARISA, A. et al. Effect of dietary oregano oil and atocopheryl acetate supplementation on iron-induced lipid oxidation of turkey breast, thigh, liver and heart tissues. Journal of Animal Physiology and Animal Nutrition, v.87, p.324-335, 2003.

PEDROSO, A.A; OETTING, L.L.; UTIYAMA, C.E. et al. Variabilidade espacial da comunidade bacteriana intestinal de suínos suplementados com antibióticos ou extratos herbais. Revista Brasileira de Zootecnia, v.34, n.5, 2005. /no prelo/

PIVA, A.; CERVELLATI, C.; BIAGI, G. et al. High dose of carvacrol, and not oregano, controls swine cecal fermentation. Journal of Animal Science, v.80, p.395, suppl. 1, 2002a.

PIVA, A.; CERVELLATI, C.; CALL, J.E. et al. Effect of carvacrol on indigenous Enterobacteriaceae levels and fermentation system. Journal of Animal Science, v.80, suppl. 1, p.395, 2002b.

PIVA, A.; GRILLI, E.; CASADEI, G. et al. Adding thymol to a broiler diet influences in vitro cecal fermentation and in vivo growth performance. Journal of Animal Science, v.82, suppl. 1, p.325, 2004.

PLATEL, K.; SRINIVASAN, K. Influence of dietary spices or their active principles on digestive enzymes of small intestinal mucosa in rats. International Journal of Food Sciences and Nutrition, v.47, p.55-59, 1996.

PLUSKE, J.R.; HAMPSON, D.J.; WILLIAMS, J.H. Factors influencing the structure and function of the small intestine in the weaned pig: a review. Livestock Production Science, v.51, p.215-236, 1997.

POZO, L.A.P. Estudo "in vitro" do efeito de extratos aquosos de plantas medicinais sobre Clostridium difficile. Viçosa, 1997. 77p. Dissertação (Mestrado) - Universidade Federal de Viçosa.

RESURRECCION, A.V.A.; REYNOLDS, A.E. Evaluation of natural antioxidants in frankfurters containing chicken and pork. Journal of Food Science, v.55, n.3, p.629-632, 1990.

ROSTAGNO, H.S.; ALBINO, L.F.T.; DONZELE, J.L. et al. Tabelas brasileiras para aves e suínos: composição de alimentos e exigências nutricionais. Viçosa: Universidade de Viçosa, 2000. 141p. 
SALVAT, A.; ANTONNACCI, L.; FORTUNATO, R.H. et al. Screening of some plants from northern Argentina for their antimicrobial activity. Letters in Applied Microbiology, v.32, p.293-297, 2001.

SAMBAIAH, K.; SRINIVASAN, K. Secretion and composition of bile in rats fed diets containing spices. Journal of Food Science and Technology, v.28, p.35-38, 1991.

SHANMUGAVELU, S.; BROOKER, J.D.; ACAMOVIC, T. et al. Effect of thyme oil and garlic powder on microbial fermentation in various sections of the gastrointestinal tract of broilers. British Poultry Science, v.45, p.S9-S11, 2004.

SILVA, E.N. Antibióticos intestinais naturais: bacteriocinas. In: SIMPÓSIO SOBRE ADITIVOS ALTERNATIVOS NA NUTRIÇÃO ANIMAL, Campinas, 2000. Anais. Campinas: CBNA, 2000. p.15-24.

SIMPSON, J.M.; McCRAKEN, V.J.; WHITE, B.A. et al. Application of denaturant gel electrophoresis for the analysis of the porcine gastrointestinal microbiota. Journal of Microbiology Methods, v.36, p.167-179, 1999.

SPRING, P.; WENK, C.; DAWSON, K.A. et al. The effect of dietary mannanoligosaccharides on cecal parameters and the concentration of enteric bacteria in the ceca of salmonella-challenged broiler chicks. Poultry Science, v.79, n.1, p. 205-211, 2001.

SREENIVASAMURTHY, V.; KRISHNAMURTHY, K. Place of spices and aromatics in Indian dietary. Food Science, v.8, p.284-288, 1959.

SRINIVASAN, D.; NATHAN, S.; SURESH, T. et al. Antimicrobial activity of certain Indian medicinal plants used in folkloric medicine. Journal of Ethnopharmacology, v.74, p.217-220, 2001.

STATISTICAL ANALYSIS SYSTEM INSTITUTE. SAS user's guide: statistics. Carry, 2001. 155p.

STEWART, C.S.; CHESSON, A. Making sense of probiotics. Pig Veterinary Journal, v.31, p.11-33, 1993.

STOKES, C.R.; BAILEY, M.; HABERSON, K. Development and function of the pig gastrointestinal immune system. In: LINDBERG, J.E.; OGLE, B (Ed.). Digestive physiology of pigs. Wallingford: CABI Publishing, 2001. cap.16, p.59-66. 
STRICKLING, J.A.; HARMON, D.L.; DAWSON, K.A. et al. Evaluation of oligosaccharide addition to dog diets: influences on nutrient digestion and microbial populations. Animal Feed Science and Technology, v.86, n.3/4, p.205-219, 2000.

SURESH, P. INGLE, V.K.; VIJAYALAKSHMI, V. Antibacterial activity of eugenol in comparison with other antibiotics. Journal of Food Science and Technology, v. 29, p.254-256, 1992.

TABAK, M.; ARMONM R.; NEEMAN, I. Cinnamon extracts inhibitory effect on Helicobacter pylori. Journal of Ethnopharmacology, v.67, p.169-277, 1991.

TANABE, H.; YOSHIDA, M.; TOMITA, N. Comparison of the antioxidant activies of 22 commonly used culinary herbs and spices on the lipid oxidation of pork meat. Animal Science Journal, v.73, p.389-393, 2002.

TANG, S.; KERRY, J.P.; SHEEHAN, D. et al. Antioxidative effect of added tea catechins on susceptibility of cooked red meat, poultry and fish patties to lipid oxidation. Food Research International, v.34, p.651-657, 2001a.

TANG, S.; KERRY, J.P.; SHEEHAN, D. et al. Antioxidative effect of dietary tea catechins on lipid oxidation of long-term frozen stored chicken meat. Meat Science, v.57, p.331-336, 2001b.

TANG, S.; SHEEHAN, D.; BUCKLEY, D.J. et al. Anti-oxidant activity of added tea catechins on lipid oxidation of raw minced red meat, poultry and fish muscle. International Journal of Food Science and Technology, v.36, p.685-692, 2001c.

TANNOCK, G.W.; TILSALA-TIMISJARVI, A.; RODTONG, S. Isolates from the gastrointestinal tract, silage and yogurt by 16S-23S rRNA geneintergenic spacer region sequence comparations. Applied and Environmental Microbiology, v.65, p.4264-4267, 1998.

TAVARES, W. Manual de antibióticos e quimioterápicos antiinfecciosos. Rio de Janeiro: Livraria Atheneu Editora, 1990. 515p.

THALER, R.C.; ROPS, B.D.; CHRISTOPHERSON, B.T. et al. Efficacy of SUPROL as a growth promotant for grow-finish pigs. Journal of Animal Science, v.82, suppl. 1, p.99, 2004.

TUCCI, F.M. Efeitos da adição de agentes tróficos na dieta de leitões desmamados sobre a renovação celular da mucosa intestinal, enzimas digestivas e desempenho. Jaboticabal, 2003. 84p. Tese (Doutorado) - Faculdade de Ciências Agrárias, Universidade Estadual Paulista “Júlio de Mesquita Filho”. 
UTIYAMA, C.E. Utilização de agentes antimicrobianos, probióticos, prebióticos e extratos vegetais como promotores do crescimento de leitões recém-desmamados. Piracicaba, 2004. 94p. Tese (Doutorado) Escola Superior de Agricultura “Luiz de Queiroz”, Universidade de São Paulo.

VIEIRA, R.H.S.F; RODRIGLES, D.P.; GONÇALVEZ, F.A. et al. Microbicidal effect of medicinal plant extract (psidium guajava Linn and Carica papaya Lin) upon bactéria isolated from fish muscle and known to induce diarrhea in children. Revista do Instituto de Medicina Tropical de São Paulo, v.43, p.145-148, 2001.

WANG, R.; LI, D.; BOURNE, S. Can 2000 years of herbal medicine history help us solve problems in year 2000?. In: ALLTECH'S ANNUAL SYMPOSIUM, 14., Nottingham, UK, 1998. Anais. Nottingham: ALLTECH, 1998. p.168-184.

YOUDIM, K.A.; DEANS, S.G. Effect of thyme oil and thymol dietary supplementation on the antioxidant status and fatty acid composition of the ageing rat brain. British Journal of Nutrition, v.83, p.87-93, 2000.

YOUDIM, K.A.; DEANS, S.G. Dietary supplementation of thyme (Thymus vulgaris L.) essential oil during the lifetime of the rat: its effects on the antioxidant status in liver, kidney and heart tissues. Mechanisms of Ageing and Development, v.109, p.163-175, 1999.

YOUNG, J.F.; STAGSTED, J.; JENSEN, S.K. et al. Ascorbic acid, $\alpha$-tocopherol and oregano supplements reduce stress-induced deterioration of chicken meat quality. Poultry Science, v.82, p.1343-1351, 2003.

ZUANON, J.A.S., FONSECA, J.B., ROSTAGNO, H.S., et al. Efeito de promotores de crescimento sobre o desenvolvimento de frangos de corte. Revista Brasileira de Zootecnia, v.27, p.999-1005, 1998.

ZUCCHI, O.L.A.D.; NASCIMENTO FILHO, V.F. Caracterização qualitativa e quantitativa de elementos, pela técnica de fluorescência de raios $X$, em suplementos minerais para animais. I. Dispersão de comprimento de onda. Pesquisa Agropecuária Brasileira, v.30, p.1427-1439, 1995. 
APÊNDICES 
APÊNDICE 1. Valores de matéria seca (\%), energia bruta (kcal/kg), proteína bruta (\%) e cromo (\%) das amostras de fezes e dietas

\begin{tabular}{lccc}
\hline \multicolumn{1}{c}{ Amostra } & Matéria seca \\
$(\%)$ & $\begin{array}{c}\text { Energia bruta }^{2} \\
(\mathrm{kcal} / \mathrm{g})\end{array}$ & $\begin{array}{c}\text { Cromo }^{2} \\
(\%)\end{array}$ \\
\hline Ração $^{3} \mathrm{C}$ & 89,73 & 4450 & 0,052 \\
Ração $^{3}$ A & 90,20 & 4573 & 0,056 \\
Ração $^{3}$ Ea & 90,60 & 4687 & 0,054 \\
Ração $^{3}$ Eb & 91,04 & 4538 & 0,051 \\
Ração $^{3}$ Ec & 91,11 & 4503 & 0,050 \\
Fezes C1 & 26,28 & 4807 & 0,205 \\
Fezes C2 & 27,23 & 4750 & 0,221 \\
Fezes C3 & 27,96 & 4598 & 0,200 \\
Fezes C4 & 25,69 & 4343 & 0,196 \\
Fezes A1 & 27,20 & 4632 & 0,224 \\
Fezes A2 & 27,78 & 4673 & 0,221 \\
Fezes A3 & 25,49 & 4969 & 0,200 \\
Fezes A4 & 24,09 & 4565 & 0,197 \\
Fezes Ea1 & 25,20 & 4999 & 0,196 \\
Fezes Ea2 & 24,78 & 4681 & 0,183 \\
Fezes Ea3 & 28,03 & 4418 & 0,185 \\
Fezes Ea4 & 24,97 & 4826 & 0,221 \\
Fezes Eb1 & 25,12 & 5189 & 0,205 \\
Fezes Eb2 & 27,42 & 4843 & 0,215 \\
Fezes Eb3 & 22,08 & 4606 & 0,194 \\
Fezes Eb4 & 25,86 & 4640 & 0,208 \\
Fezes Ec1 & 25,22 & 4786 & 0,217 \\
Fezes Ec2 & 28,05 & 4634 & 0,237 \\
Fezes Ec3 & 24,92 & 4904 & 0,197 \\
Fezes Ec4 & 24,45 & 4558 & 0,221 \\
\hline 1 & & &
\end{tabular}

${ }^{1} \mathrm{C}=$ controle; A=antibiótico; Ea, Eb e Ec = 700, 1400 e 2100ppm de extrato vegetal

${ }^{2}$ Valores expressos com base na matéria seca

${ }^{3}$ Ração inicial com 0,05\% de cromo 
APÊNDICE 2. Peso vivo (kg) dos animais ao $1^{\circ}, 14^{\circ}$ e $35^{\circ}$ dia dos Experimento I, II e III, considerando a média da unidade experimental

\begin{tabular}{|c|c|c|c|c|c|c|}
\hline \multirow{2}{*}{$\begin{array}{c}\text { Dias de } \\
\text { experimento }\end{array}$} & \multirow[b]{2}{*}{ Bloco } & \multicolumn{5}{|c|}{ Tratamento $^{1}$} \\
\hline & & C & A & $\mathrm{Ea}$ & $\mathrm{Eb}$ & $\mathrm{Ec}$ \\
\hline \multirow{13}{*}{$\begin{array}{c}1^{\circ} \\
\text { dia }\end{array}$} & 1 & 5,990 & 5,950 & 5,930 & 5,920 & 5,940 \\
\hline & 2 & 5,600 & 5,630 & 5.670 & 5,640 & 5.580 \\
\hline & 3 & 5.400 & 5.370 & 5.420 & 5.390 & 5.430 \\
\hline & 4 & 5,030 & 5,050 & 5,100 & 5.110 & 5.110 \\
\hline & 5 & 5.610 & 5.650 & 5.610 & 5.530 & 5.590 \\
\hline & 6 & 5,420 & 5.400 & 5.420 & 5,430 & 5,410 \\
\hline & 7 & 5.230 & 5.260 & 5.260 & 5.260 & 5.230 \\
\hline & 8 & 5.050 & 5.030 & 5,110 & 5.070 & 5.040 \\
\hline & 9 & 5,730 & 5.720 & 5.730 & 5.740 & 5,700 \\
\hline & 10 & 5.500 & 5.450 & 5.520 & 5.470 & 5.540 \\
\hline & 11 & 5,270 & 5,280 & 5.270 & 5.270 & 5,280 \\
\hline & 12 & 5,020 & 5,090 & 5,050 & 5,090 & 5,040 \\
\hline & Média & 5,404 & 5,407 & 5,424 & 5,410 & 5,408 \\
\hline \multirow{13}{*}{$\begin{array}{l}14^{\circ} \\
\text { dia }\end{array}$} & 1 & 8,750 & 8,890 & 8,030 & 8,480 & 8,320 \\
\hline & 2 & 8.090 & 6.400 & 7.340 & 7.610 & 9.170 \\
\hline & 3 & 7.370 & 6.100 & 8.060 & 7.700 & 9.140 \\
\hline & 4 & 7.070 & 5.370 & 7.220 & 7.170 & 8.320 \\
\hline & 5 & 8.560 & 10.110 & 8.940 & 8.800 & 8,090 \\
\hline & 6 & 8.480 & 8.570 & 7.810 & 7.470 & 8.340 \\
\hline & 7 & 6.950 & 8.950 & 7.140 & 7.790 & 6.700 \\
\hline & 8 & 7.100 & 7.870 & 6.670 & 7.720 & 7.730 \\
\hline & 9 & 7.320 & 8.760 & 7.430 & 7.100 & 7.090 \\
\hline & 10 & 7.800 & 8.950 & 8.070 & 7.400 & 8.270 \\
\hline & 11 & 6.510 & 7.830 & 6.190 & 6.290 & 8,230 \\
\hline & 12 & 9.280 & 7.050 & 7.680 & 6.890 & 6.690 \\
\hline & Média & 7,773 & 7,904 & 7,548 & 7,535 & 8,008 \\
\hline \multirow{13}{*}{$\begin{array}{l}35^{\circ} \\
\text { dia }\end{array}$} & 1 & 20,910 & 19,420 & 16,940 & 17,870 & 16,780 \\
\hline & 2 & 15.980 & 20.550 & 14.200 & 14.170 & 21.200 \\
\hline & 3 & 17.390 & 20.310 & 17.580 & 16.740 & 20.440 \\
\hline & 4 & 15.670 & 15,560 & 16.410 & 15.730 & 20,060 \\
\hline & 5 & 19.750 & 24.710 & 20.900 & 18.720 & 16.100 \\
\hline & 6 & 20.310 & 19.460 & 18.450 & 13.810 & 17.110 \\
\hline & 7 & 14.140 & 20.990 & 17.890 & 17.740 & 16.470 \\
\hline & 8 & 17.290 & 17.660 & 15.190 & 18.720 & 17.390 \\
\hline & 9 & 16.380 & 20.260 & 13.030 & 14.490 & 15.580 \\
\hline & 10 & 18.390 & 20.310 & 20.500 & 16.280 & 17.310 \\
\hline & 11 & 15.250 & 18.440 & 17.520 & 15.670 & 18,180 \\
\hline & 12 & 19.460 & 16.190 & 17.500 & 14.800 & 15.000 \\
\hline & Média & 17,577 & 19,488 & 17,176 & 16,228 & 17,635 \\
\hline
\end{tabular}

${ }^{1} \mathrm{C}=$ controle; $\mathrm{A}=$ antibiótico; Ea, Eb e Ec $=700,1400$ e 2100 ppm de extrato vegetal 
APÊNDICE 3. Consumo diário de ração por leitão $(\mathrm{kg})$ nos períodos de 1 a 14, 15 a 35 e 1 a 35 dias dos Experimentos I, II e III, considerando a média da unidade experimental

\begin{tabular}{|c|c|c|c|c|c|c|}
\hline \multirow{2}{*}{$\begin{array}{c}\text { Dias de } \\
\text { experimento }\end{array}$} & \multirow[b]{2}{*}{ Bloco } & \multicolumn{5}{|c|}{ Tratamento $^{1}$} \\
\hline & & $\mathrm{C}$ & $\mathrm{A}$ & $\mathrm{Ea}$ & $\mathrm{Eb}$ & Ec \\
\hline \multirow{13}{*}{$\begin{array}{c}1 \text { a } 14 \\
\text { dias }\end{array}$} & 1 & 0,298 & 0,305 & 0,278 & 0,274 & 0,269 \\
\hline & 2 & 0.263 & 0.355 & 0.240 & 0.213 & 0.344 \\
\hline & 3 & 0.223 & 0.343 & 0.258 & 0.239 & 0.386 \\
\hline & 4 & 0.256 & 0.260 & 0.236 & 0.242 & 0,290 \\
\hline & 5 & 0.313 & 0.433 & 0.311 & 0.344 & 0.251 \\
\hline & 6 & 0.316 & 0,306 & 0.292 & 0.274 & 0.318 \\
\hline & 7 & 0.223 & 0.320 & 0,216 & 0.251 & 0.243 \\
\hline & 8 & 0.273 & 0.289 & 0.223 & 0.170 & 0.215 \\
\hline & 9 & 0.216 & 0,309 & 0.223 & 0.194 & 0.203 \\
\hline & 10 & 0.240 & 0,334 & 0.324 & 0.221 & 0.293 \\
\hline & 11 & 0.223 & 0.295 & 0.243 & 0.207 & 0.336 \\
\hline & 12 & 0,318 & 0.248 & 0.294 & 0.239 & 0,238 \\
\hline & Média & 0,264 & 0,316 & 0,262 & 0,239 & 0,282 \\
\hline \multirow{13}{*}{$\begin{array}{c}15 \text { a } 35 \\
\text { dias }\end{array}$} & 1 & 0,833 & 0,731 & 0,668 & 0,641 & 0,649 \\
\hline & 2 & 0.657 & 0.754 & 0.576 & 0.458 & 0.862 \\
\hline & 3 & 0.771 & 0.909 & 0.688 & 0.644 & 0.838 \\
\hline & 4 & 0.655 & 0.595 & 0.655 & 0.586 & 0.598 \\
\hline & 5 & 0.803 & 1.018 & 0.830 & 0.727 & 0.567 \\
\hline & 6 & 0.850 & 0.783 & 0.779 & 0.556 & 0.767 \\
\hline & 7 & 0.683 & 0.810 & 0.715 & 0.720 & 0.665 \\
\hline & 8 & 0.715 & 0.728 & 0.594 & 0.793 & 0.706 \\
\hline & 9 & 0,884 & 1.185 & 0.882 & 0.813 & 0.934 \\
\hline & 10 & 1,089 & 1,166 & 1.268 & 1.023 & 1.057 \\
\hline & 11 & 0.944 & 1.162 & 0.877 & 0.991 & 1.179 \\
\hline & 12 & 0.948 & 1.114 & 1.187 & 0.974 & 1.022 \\
\hline & Média & 0,819 & 0,913 & 0,810 & 0,744 & 0,820 \\
\hline \multirow{13}{*}{$\begin{array}{c}1 \text { a } 35 \\
\text { dias }\end{array}$} & 1 & 0,619 & 0,560 & 0,512 & 0,494 & 0,497 \\
\hline & 2 & 0.499 & 0.594 & 0.442 & 0.360 & 0.655 \\
\hline & 3 & 0.551 & 0.683 & 0.516 & 0.482 & 0.657 \\
\hline & 4 & 0,496 & 0,461 & 0,488 & 0.367 & 0.475 \\
\hline & 5 & 0.607 & 0.784 & 0.623 & 0.573 & 0.441 \\
\hline & 6 & 0.637 & 0.592 & 0.584 & 0.444 & 0.587 \\
\hline & 7 & 0.499 & 0.614 & 0.515 & 0.532 & 0.496 \\
\hline & 8 & 0.538 & 0.552 & 0.446 & 0.590 & 0.538 \\
\hline & 9 & 0.617 & 0,835 & 0.618 & 0.565 & 0.642 \\
\hline & 10 & 0.749 & 0.833 & 0.891 & 0.702 & 0.752 \\
\hline & 11 & 0.656 & 0.816 & 0,624 & 0.677 & 0.842 \\
\hline & 12 & 0.696 & 0.767 & 0.830 & 0.680 & 0.708 \\
\hline & Média & 0,597 & 0,674 & 0,591 & 0,539 & 0,608 \\
\hline
\end{tabular}

${ }^{1} \mathrm{C}=$ controle; $\mathrm{A}=$ antibiótico; Ea, Eb e Ec = 700, 1400 e 2100 ppm de extrato vegetal 
APÊNDICE 4. Ganho diário de peso por leitão $(\mathrm{kg})$ nos períodos de 1 a 14,15 a 35 e 1 a 35 dias dos Experimentos I, II e III, considerando a média da unidade experimental

\begin{tabular}{|c|c|c|c|c|c|c|}
\hline \multirow{2}{*}{$\begin{array}{c}\text { Dias de } \\
\text { experimento }\end{array}$} & \multirow[b]{2}{*}{ Bloco } & \multicolumn{5}{|c|}{ Tratamento $^{1}$} \\
\hline & & C & A & $\mathrm{Ea}$ & $\mathrm{Eb}$ & Ec \\
\hline \multirow{13}{*}{$\begin{array}{c}1 \text { a } 14 \\
\text { dias }\end{array}$} & 1 & 0,197 & 0,210 & 0,150 & 0,183 & 0,170 \\
\hline & 2 & 0.178 & 0,242 & 0.119 & 0.141 & 0.256 \\
\hline & 3 & 0.141 & 0.221 & 0.189 & 0.165 & 0.265 \\
\hline & 4 & 0,146 & 0.151 & 0,151 & 0.147 & 0.229 \\
\hline & 5 & 0.211 & 0.319 & 0.238 & 0.234 & 0.179 \\
\hline & 6 & 0.219 & 0.226 & 0.171 & 0.146 & 0.209 \\
\hline & 7 & 0.123 & 0.264 & 0.134 & 0.181 & 0.105 \\
\hline & 8 & 0.146 & 0.203 & 0.111 & 0.189 & 0.192 \\
\hline & 9 & 0.114 & 0.217 & 0.121 & 0.097 & 0.099 \\
\hline & 10 & 0.164 & 0.250 & 0.182 & 0.138 & 0.195 \\
\hline & 11 & 0.089 & 0.182 & 0.066 & 0.073 & 0.211 \\
\hline & 12 & 0,304 & 0,140 & 0,188 & 0,129 & 0,118 \\
\hline & Média & 0,169 & 0,219 & 0,152 & 0,152 & 0,186 \\
\hline \multirow{13}{*}{$\begin{array}{c}15 \text { a } 35 \\
\text { dias }\end{array}$} & 1 & 0,579 & 0,501 & 0,424 & 0,447 & 0,403 \\
\hline & 2 & 0.376 & 0.549 & 0.327 & 0.312 & 0.573 \\
\hline & 3 & 0.477 & 0.564 & 0.453 & 0.430 & 0.538 \\
\hline & 4 & 0.410 & 0.400 & 0.438 & 0.408 & 0.559 \\
\hline & 5 & 0.533 & 0.695 & 0.570 & 0.472 & 0.381 \\
\hline & 6 & 0.563 & 0.519 & 0.507 & 0,302 & 0.418 \\
\hline & 7 & 0,342 & 0.573 & 0.512 & 0.474 & 0.465 \\
\hline & 8 & 0.485 & 0.466 & 0.406 & 0.524 & 0.460 \\
\hline & 9 & 0,431 & 0.548 & 0.267 & 0.352 & 0.404 \\
\hline & 10 & 0.504 & 0.541 & 0.592 & 0.423 & 0.430 \\
\hline & 11 & 0.416 & 0.505 & 0.540 & 0.447 & 0.474 \\
\hline & 12 & 0.485 & 0.435 & 0.468 & 0.377 & 0.396 \\
\hline & Média & 0,467 & 0,525 & 0,459 & 0,414 & 0,458 \\
\hline \multirow{13}{*}{$\begin{array}{c}1 \text { a } 35 \\
\text { dias }\end{array}$} & 1 & 0,426 & 0,385 & 0,315 & 0,341 & 0,310 \\
\hline & 2 & 0.297 & 0.426 & 0.244 & 0.244 & 0.446 \\
\hline & 3 & 0.343 & 0.427 & 0.347 & 0.324 & 0.429 \\
\hline & 4 & 0.304 & 0,300 & 0.323 & 0.303 & 0.427 \\
\hline & 5 & 0.404 & 0.545 & 0.437 & 0.377 & 0.300 \\
\hline & 6 & 0.425 & 0.402 & 0.372 & 0.239 & 0.334 \\
\hline & 7 & 0.255 & 0.449 & 0.361 & 0.357 & 0.321 \\
\hline & 8 & 0.350 & 0.361 & 0.288 & 0.390 & 0.353 \\
\hline & 9 & 0,304 & 0,415 & 0,209 & 0.250 & 0.282 \\
\hline & 10 & 0.368 & 0.425 & 0.428 & 0,309 & 0,336 \\
\hline & 11 & 0.285 & 0.376 & 0,350 & 0.297 & 0.369 \\
\hline & 12 & 0.413 & 0.317 & 0.356 & 0.277 & 0.285 \\
\hline & Média & 0,348 & 0,402 & 0,336 & 0,309 & 0,349 \\
\hline
\end{tabular}

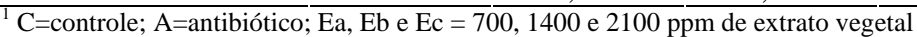


APÊNDICE 5. Conversão alimentar nos períodos de 1 a 14, 15 a 35 e 1 a 35 dias dos Experimentos I, II e III, considerando a média da unidade experimental

\begin{tabular}{|c|c|c|c|c|c|c|}
\hline \multirow{2}{*}{$\begin{array}{c}\text { Dias de } \\
\text { experimento }\end{array}$} & \multirow[b]{2}{*}{ Bloco } & \multicolumn{5}{|c|}{ Tratamento $^{1}$} \\
\hline & & $\mathrm{C}$ & $\mathrm{A}$ & $\mathrm{Ea}$ & $\mathrm{Eb}$ & Ec \\
\hline \multirow{13}{*}{$\begin{array}{c}1 \text { a } 14 \\
\text { dias }\end{array}$} & 1 & 1,514 & 1,451 & 1,855 & 1,496 & 1,582 \\
\hline & 2 & 1.476 & 1.468 & 2.013 & 1.510 & 1.341 \\
\hline & 3 & 1.582 & 1.550 & 1.366 & 1.449 & 1.458 \\
\hline & 4 & 1.760 & 1.727 & 1.561 & 1.644 & 1.588 \\
\hline & 5 & 1.487 & 1.360 & 1.307 & 1.472 & 1.408 \\
\hline & 6 & 1.447 & 1.350 & 1.708 & 1.884 & 1.518 \\
\hline & 7 & 1.817 & 1.215 & 1.612 & 1.388 & 2.310 \\
\hline & 8 & 1.867 & 1.423 & 2.002 & 1.517 & 1.492 \\
\hline & 9 & 3.805 & 2.847 & 3.674 & 4.004 & 4.097 \\
\hline & 10 & 2.924 & 2.673 & 3.559 & 3.210 & 3.009 \\
\hline & 11 & 5.036 & 3.243 & 7.386 & 5.681 & 3.190 \\
\hline & 12 & 2.092 & 3.538 & 3.125 & 3.714 & 4.033 \\
\hline & Média & 2,234 & 1,987 & 2,597 & 2,414 & 2,252 \\
\hline \multirow{13}{*}{$\begin{array}{c}15 \text { a } 35 \\
\text { dias }\end{array}$} & 1 & 1,452 & 1,420 & 1,535 & 1,263 & 1,576 \\
\hline & 2 & 2.128 & 1.213 & 2.026 & 1.594 & 1.505 \\
\hline & 3 & 1.444 & 1.397 & 1.403 & 1.353 & 1.612 \\
\hline & 4 & 1.466 & 1.596 & 1.802 & 1.609 & 1.288 \\
\hline & 5 & 1.507 & 1.464 & 1.458 & 1.538 & 1.486 \\
\hline & 6 & 1.509 & 1.511 & 1.538 & 1.842 & 1.836 \\
\hline & 7 & 1.994 & 1.412 & 1.396 & 1.519 & 1.430 \\
\hline & 8 & 1.474 & 1.561 & 1.464 & 1.513 & 1.534 \\
\hline & 9 & 1.844 & 2.000 & 2.210 & 1.497 & 1.676 \\
\hline & 10 & 1.941 & 1.860 & 2.00 .5 & 1.867 & 2.02 .9 \\
\hline & 11 & 1.704 & 2.082 & 1.175 & 2.062 & 2.106 \\
\hline & 12 & 1.583 & 2.156 & 2.341 & 2.188 & 1.809 \\
\hline & Média & 1,671 & 1,639 & 1,696 & 1,654 & 1,657 \\
\hline \multirow{13}{*}{$\begin{array}{l}1 \text { a } 35 \\
\text { dias }\end{array}$} & 1 & 1,480 & 1,434 & 1,668 & 1,358 & 1,579 \\
\hline & 2 & 1.802 & 1.333 & 2.020 & 1.551 & 1.426 \\
\hline & 3 & 1.4 .94 & 1.457 & 1.387 & 1.392 & 1.5 .37 \\
\hline & 4 & 1.585 & 1.656 & 1.688 & 1.626 & 1.3999 \\
\hline & 5 & 1.50 .3 & 1.440 & 1.425 & 1.522 & 1.467 \\
\hline & 6 & 1.4 .96 & 1.475 & 1.56 .9 & 1.852 & 1.757 \\
\hline & 7 & 1.960 & 1.366 & 1.428 & 1.492 & 1.545 \\
\hline & 8 & 1.540 & 1.530 & 1.547 & 1.514 & 1.525 \\
\hline & 9 & 2.137 & 2.177 & 2.551 & 1.886 & 2.017 \\
\hline & 10 & 2.117 & 2.051 & 2.270 & 2.106 & 2.257 \\
\hline & 11 & 2.118 & 2.307 & 1.641 & 2.417 & 2.354 \\
\hline & 12 & 1.733 & 2.400 & 2.507 & 2.471 & 2.178 \\
\hline & Média & 1,747 & 1,719 & 1,808 & 1,766 & 1,753 \\
\hline
\end{tabular}

${ }^{1} \mathrm{C}=$ controle; A=antibiótico; Ea, Eb e Ec = 700, 1400 e 2100 ppm de extrato vegetal 
APÊNDICE 6. Temperaturas máximas e mínimas durante o Experimento I

\begin{tabular}{|c|c|c|c|c|c|}
\hline Data & Mínima & Máxima & Data & Mínima & Máxima \\
\hline $09 / 9 / 2003$ & --- & 23,5 & $28 / 9 / 2003$ & 17,5 & 30,5 \\
\hline $10 / 9 / 2003$ & 19,0 & 22,5 & $29 / 9 / 2003$ & 19,0 & 29,0 \\
\hline $11 / 9 / 2003$ & 15,0 & 25,0 & $30 / 9 / 2003$ & 19,0 & 30,0 \\
\hline $12 / 9 / 2003$ & 12,0 & 27,0 & $1 / 10 / 2003$ & 15,5 & 30,0 \\
\hline $13 / 9 / 2003$ & 17,0 & 24,5 & $2 / 10 / 2003$ & 17,0 & 32,0 \\
\hline $14 / 9 / 2003$ & 17,5 & 25,0 & $3 / 10 / 2003$ & 19,0 & 32,0 \\
\hline $15 / 9 / 2003$ & 14,5 & 28,5 & $4 / 10 / 2003$ & 20,0 & 33,0 \\
\hline $16 / 9 / 2003$ & 15,0 & 28,0 & $5 / 10 / 2003$ & 19,5 & 34,0 \\
\hline $17 / 9 / 2003$ & 16,0 & 24,5 & $6 / 10 / 2003$ & 19,5 & 30,0 \\
\hline $18 / 9 / 2003$ & 15,0 & 27,5 & $7 / 10 / 2003$ & 23,0 & 22,0 \\
\hline $19 / 9 / 2003$ & 16,0 & 30,0 & $8 / 10 / 2003$ & 20,0 & 25,0 \\
\hline $20 / 9 / 2003$ & 20,0 & 33,0 & $9 / 10 / 2003$ & 21,0 & 31,5 \\
\hline $21 / 9 / 2003$ & 20,0 & 30,5 & $10 / 10 / 2003$ & 19,5 & 28,0 \\
\hline $22 / 9 / 2003$ & 18,5 & 33,0 & $11 / 10 / 2003$ & 19,0 & 20,5 \\
\hline $23 / 9 / 2003$ & 20,0 & 33,5 & $12 / 10 / 2003$ & 16,0 & 24,0 \\
\hline $24 / 9 / 2003$ & 21,5 & 35,0 & $13 / 10 / 2003$ & 16,0 & 26,5 \\
\hline $25 / 9 / 2003$ & 20,0 & 33,0 & $14 / 10 / 2003$ & 16,0 & --- \\
\hline $26 / 9 / 2003$ & 21,0 & 26,0 & Média & 18,11 & 28,37 \\
\hline $27 / 9 / 2003$ & 19,5 & 25,0 & Desvio Padrão & 2,41 & 3,88 \\
\hline
\end{tabular}


APÊNDICE 7. Temperaturas máximas e mínimas durante o Experimento II

\begin{tabular}{|c|c|c|c|c|c|}
\hline Data & Mínima & Máxima & Data & Mínima & Máxima \\
\hline $21 / 10 / 2003$ & --- & 34,0 & $9 / 11 / 2003$ & 20,5 & 33,0 \\
\hline $22 / 10 / 2003$ & 15,0 & 29,0 & $10 / 11 / 2003$ & 20,0 & 34,5 \\
\hline $23 / 10 / 2003$ & 22,0 & 29,0 & $11 / 11 / 2003$ & 22,5 & 35,0 \\
\hline $24 / 10 / 2003$ & 21,5 & 32,0 & $12 / 11 / 2003$ & 25,0 & 26,0 \\
\hline $25 / 10 / 2003$ & 21,0 & 31,0 & $13 / 11 / 2003$ & 20,5 & 28,0 \\
\hline $26 / 10 / 2003$ & 23,0 & 33,0 & $14 / 11 / 2003$ & 19,0 & 30,5 \\
\hline $27 / 10 / 2003$ & 24,0 & 24,5 & $15 / 11 / 2003$ & 20,5 & 32,0 \\
\hline $28 / 10 / 2003$ & 20,0 & 24,0 & $16 / 11 / 2003$ & 21,0 & 32,0 \\
\hline $29 / 10 / 2003$ & 19,5 & 26,5 & $17 / 11 / 2003$ & 22,5 & 28,0 \\
\hline $30 / 10 / 2003$ & 21,0 & 29,0 & $18 / 11 / 2003$ & 21,0 & 27,5 \\
\hline $31 / 10 / 2003$ & 21,0 & 31,0 & $19 / 11 / 2003$ & 22,0 & 25,0 \\
\hline $1 / 11 / 2003$ & 21,0 & 27,0 & $20 / 11 / 2003$ & 18,5 & 27,0 \\
\hline $2 / 11 / 2003$ & 17,0 & 22,0 & $21 / 11 / 2003$ & 22,0 & 28,0 \\
\hline $3 / 11 / 2003$ & 17,0 & 26,5 & $22 / 11 / 2003$ & 20,0 & 30,0 \\
\hline $4 / 11 / 2003$ & 18,0 & 28,0 & $23 / 11 / 2003$ & 20,0 & 29,0 \\
\hline $5 / 11 / 2003$ & 20,0 & 27,0 & $24 / 11 / 2003$ & 18,0 & 26,0 \\
\hline $6 / 11 / 2003$ & 18,0 & 29,0 & $25 / 11 / 2003$ & 21,0 & --- \\
\hline $7 / 11 / 2003$ & 20,0 & 30,0 & Média & 20,38 & 29,01 \\
\hline $8 / 11 / 2003$ & 15,0 & 31,5 & $D$. Padrão & 2,05 & 3,10 \\
\hline
\end{tabular}


APÊNDICE 8. Temperaturas máximas e mínimas durante o Experimento III

\begin{tabular}{|c|c|c|c|c|c|}
\hline Data & Mínima & Máxima & Data & Mínima & Máxima \\
\hline $17 / 2 / 2004$ & --- & 31,0 & $7 / 3 / 2004$ & 21,0 & 29,0 \\
\hline $18 / 2 / 2004$ & 21,0 & 32,0 & $8 / 3 / 2004$ & 21,5 & 29,5 \\
\hline $19 / 2 / 2004$ & 23,0 & 32,5 & $9 / 3 / 2004$ & 22,0 & 31,5 \\
\hline $20 / 2 / 2004$ & 24,0 & 31,5 & $10 / 3 / 2004$ & 21,5 & 32,0 \\
\hline $21 / 2 / 2004$ & 22,5 & 29,5 & $11 / 3 / 2004$ & 21,5 & 30,0 \\
\hline $22 / 2 / 2004$ & 22,5 & 27,0 & $12 / 3 / 2004$ & 22,0 & 28,0 \\
\hline $23 / 2 / 2004$ & 19,0 & 24,0 & $13 / 3 / 2004$ & 22,0 & 30,0 \\
\hline $24 / 2 / 2004$ & 21,0 & 24,0 & $14 / 3 / 2004$ & 22,5 & 30,0 \\
\hline $25 / 2 / 2004$ & 21, & 24,0 & $15 / 3 / 2004$ & 22,5 & 29,0 \\
\hline $26 / 2 / 2004$ & 19,5 & 28,0 & $16 / 3 / 2004$ & 19,0 & 30,0 \\
\hline $27 / 2 / 2004$ & 19,0 & 28,5 & $17 / 3 / 2004$ & 19,5 & 29,5 \\
\hline $28 / 2 / 2004$ & 20,0 & 28,5 & $18 / 3 / 2004$ & 19,0 & 31,5 \\
\hline $29 / 2 / 2004$ & 20,0 & 29,0 & $19 / 3 / 2004$ & 20,0 & 29,0 \\
\hline $1 / 3 / 2004$ & 20,0 & 31,0 & $20 / 3 / 2004$ & 20,0 & 27,0 \\
\hline $2 / 3 / 2004$ & 20,0 & 31,5 & $21 / 3 / 2004$ & 18,5 & 29,0 \\
\hline $3 / 3 / 2004$ & 21,0 & 32,0 & $22 / 3 / 2004$ & 17,5 & 30,0 \\
\hline $4 / 3 / 2004$ & 22,0 & 27,5 & $23 / 3 / 2004$ & 18,0 & --- \\
\hline $5 / 3 / 2004$ & 22,0 & 26,0 & Média & 20,80 & 29,12 \\
\hline $6 / 3 / 2004$ & 22,0 & 27,0 & $D$. Padrão & 1,53 & 2,28 \\
\hline & & & & & \\
\hline
\end{tabular}


APÊNDICE 9. Pesos absolutos (g) dos órgãos digestórios e peso vivo dos animais abatidos ao final do Experimento I e III

\begin{tabular}{|c|c|c|c|c|c|c|c|c|c|}
\hline Trat $^{1}$ & Bloco & $\begin{array}{l}\text { TGI }^{2} \text { total } \\
\text { (g) }\end{array}$ & $\begin{array}{c}\text { Estômago } \\
\text { vazio (g) }\end{array}$ & $\begin{array}{l}\text { Pâncreas } \\
\text { (g) }\end{array}$ & $\begin{array}{l}\text { Fígado } \\
\text { (g) }\end{array}$ & $\begin{array}{l}\text { Vesícula } \\
\text { biliar (g) }\end{array}$ & $\begin{array}{l}\text { ID }^{3} \text { vazio } \\
\text { (g) }\end{array}$ & $\begin{array}{c}\mathrm{IG}^{4} \text { vazio } \\
\text { (g) }\end{array}$ & $\begin{array}{l}\text { Peso vivo } \\
\text { (g) }\end{array}$ \\
\hline $\mathrm{C}$ & 1 & --- & 175 & 16,37 & 650 & 22,37 & 695 & 451 & 21640 \\
\hline $\mathrm{C}$ & 2 & 4275 & 155 & 27,93 & 550 & 19,85 & 695 & 493 & 17380 \\
\hline $\mathrm{C}$ & 3 & 3605 & 145 & 39,45 & 180 & 15,96 & 700 & 306 & 17960 \\
\hline $\mathrm{C}$ & 4 & 3575 & 140 & 40,74 & 450 & 6,30 & 765 & 316 & 18360 \\
\hline $\mathrm{C}$ & 5 & 3510 & 140 & 47,00 & 470 & 12,14 & 825 & 313 & 19000 \\
\hline $\mathrm{C}$ & 6 & 3860 & 175 & 43,08 & 605 & 22,13 & 925 & 353 & 19520 \\
\hline $\mathrm{C}$ & 7 & 3320 & 130 & 42,27 & 485 & 14,32 & 795 & 386 & 16440 \\
\hline $\mathrm{C}$ & 8 & 4360 & 165 & 38,39 & 640 & 36,37 & 1090 & 450 & 19460 \\
\hline A & 1 & 3660 & 145 & 21,73 & 560 & 25,25 & 590 & 246 & 19560 \\
\hline A & 2 & 3630 & 135 & 39,79 & 415 & 22,06 & 725 & 383 & 20740 \\
\hline A & 3 & 4090 & 160 & 46,25 & 580 & 10,30 & 905 & 389 & 22540 \\
\hline A & 4 & 3460 & 145 & 33,54 & 575 & 3,58 & 655 & 361 & 19780 \\
\hline A & 5 & 3910 & 136 & 38,34 & 590 & 23,94 & 885 & 391 & 20160 \\
\hline A & 6 & --- & 149 & 44,30 & 645 & 17,09 & 785 & 369 & 20600 \\
\hline A & 7 & 3830 & 139 & 36,90 & 590 & 17,30 & 1000 & 300 & 20420 \\
\hline A & 8 & 3465 & 141 & 29,29 & 420 & 9,66 & 765 & 317 & 17060 \\
\hline $\mathrm{Ea}$ & 1 & --- & 140 & 33,26 & 495 & 10,44 & 640 & 321 & 17900 \\
\hline Ea & 2 & 3070 & 135 & 40,22 & 485 & 13,85 & 535 & 248 & 14200 \\
\hline $\mathrm{Ea}$ & 3 & 3455 & 135 & 41,85 & 545 & 7,85 & 740 & 349 & 19420 \\
\hline $\mathrm{Ea}$ & 4 & 3280 & 145 & 37,42 & 420 & 11,13 & 715 & 341 & 16180 \\
\hline $\mathrm{Ea}$ & 5 & 3135 & 130 & 34,35 & 440 & 5,70 & 830 & 299 & 15460 \\
\hline $\mathrm{Ea}$ & 6 & 4050 & 148 & 28,66 & 610 & 30,09 & 985 & 360 & 21080 \\
\hline $\mathrm{Ea}$ & 7 & 3345 & 118 & 43,54 & 585 & 11,50 & 1015 & 283 & 17520 \\
\hline $\mathrm{Ea}$ & 8 & 3770 & 185 & 30,00 & 460 & 15,17 & 920 & 228 & 17600 \\
\hline $\mathrm{Eb}$ & 1 & 4155 & 145 & 42,67 & 560 & 8,50 & 865 & 490 & 18560 \\
\hline $\mathrm{Eb}$ & 2 & 3220 & 105 & 33,95 & 440 & 12,23 & 630 & 346 & 15800 \\
\hline $\mathrm{Eb}$ & 3 & 3205 & 125 & 27,62 & 420 & 9,96 & 690 & 313 & 17040 \\
\hline $\mathrm{Eb}$ & 4 & 3425 & 130 & 30,45 & 460 & 15,66 & 585 & 283 & 15780 \\
\hline $\mathrm{Eb}$ & 5 & --- & 95 & 23,43 & 430 & 20,21 & 815 & 290 & 16560 \\
\hline $\mathrm{Eb}$ & 6 & 3940 & 130 & 38,40 & 530 & 15,29 & 890 & 377 & 16800 \\
\hline $\mathrm{Eb}$ & 7 & 3290 & 155 & 32,48 & 510 & 17,16 & 890 & 325 & 16520 \\
\hline $\mathrm{Eb}$ & 8 & 3475 & 135 & 28,02 & 445 & 12,31 & 1050 & 268 & 15860 \\
\hline Ec & 1 & 3690 & 135 & --- & 515 & 14,57 & 850 & 384 & 17740 \\
\hline Ec & 2 & 4030 & 145 & 48,95 & 660 & 18,72 & 730 & 419 & 21240 \\
\hline Ec & 3 & 4270 & 170 & 47,48 & 645 & 14,61 & 920 & 328 & 20820 \\
\hline Ec & 4 & 3805 & 160 & 38,92 & 530 & 9,57 & 740 & 396 & 20060 \\
\hline Ec & 5 & 3360 & 147 & 34,22 & 440 & 15,83 & 870 & 311 & 17220 \\
\hline Ec & 6 & 4410 & 141 & 42,58 & 580 & 20,64 & 1060 & 384 & 18360 \\
\hline Ec & 7 & 4020 & 155 & 40,19 & 585 & 24,37 & 965 & 285 & 19300 \\
\hline Ec & 8 & 3590 & 125 & 26,81 & 515 & 12,75 & 985 & 387 & 16460 \\
\hline
\end{tabular}


APÊNDICE 10. Pesos absolutos (g) dos órgãos digestórios e não digestórios, assim como do comprimento e da relação peso:comprimento do intestino delgado e peso vivo dos animais abatidos ao final do Experimento I e III

\begin{tabular}{|c|c|c|c|c|c|c|c|c|c|c|}
\hline Trat $^{1}$ & Bloco & $\begin{array}{c}\text { Ceco } \\
\text { vazio (g) }\end{array}$ & $\begin{array}{c}\text { Colo } \\
\text { vazio (g) }\end{array}$ & $\begin{array}{l}\text { Pulmão } \\
\text { (g) }\end{array}$ & $\begin{array}{l}\text { Coração } \\
\text { (g) }\end{array}$ & $\begin{array}{l}\text { Rins } \\
\text { (g) }\end{array}$ & $\begin{array}{c}\text { Baço } \\
\text { (g) }\end{array}$ & $\begin{array}{c}\text { Comp }^{2} \\
(\mathrm{~m})\end{array}$ & $\begin{array}{c}\text { Rel. P/C } \\
(\mathrm{g} / \mathrm{m})^{3}\end{array}$ & $\begin{array}{c}\text { Peso } \\
\text { vivo (g) }\end{array}$ \\
\hline $\mathrm{C}$ & 1 & 51,97 & 400 & 245 & 110 & 121 & 56,46 & 10,20 & 68,14 & 21640 \\
\hline C & 2 & 48,31 & 445 & 215 & 34 & 83 & 28,63 & 11,65 & 59,66 & 17380 \\
\hline $\mathrm{C}$ & 3 & 26,69 & 280 & 260 & 91 & 94 & 24,09 & 13,80 & 50,72 & 17960 \\
\hline $\mathrm{C}$ & 4 & 41,62 & 275 & 235 & 91 & 94 & 43,25 & 13,10 & 58,40 & 18360 \\
\hline $\mathrm{C}$ & 5 & 33,40 & 280 & 190 & 95 & 105 & 35,00 & 10,60 & 77,83 & 19000 \\
\hline $\mathrm{C}$ & 6 & 47,74 & 305 & 295 & 110 & 110 & 36,10 & 10,80 & 85,65 & 19520 \\
\hline $\mathrm{C}$ & 7 & 41,34 & 345 & 280 & 95 & 110 & 42,27 & 12,00 & 66,25 & 16440 \\
\hline $\mathrm{C}$ & 8 & 65,19 & 385 & 280 & 120 & 120 & 38,39 & 17,00 & 64,12 & 19460 \\
\hline A & 1 & 36,21 & 210 & 255 & 101 & 118 & 49,65 & 11,30 & 52,21 & 19560 \\
\hline A & 2 & 33,13 & 350 & 260 & 98 & 104 & 55,56 & 11,44 & 63,37 & 20740 \\
\hline A & 3 & 34,60 & 355 & 250 & 118 & 124 & 42,20 & 15,27 & 59,27 & 22540 \\
\hline A & 4 & 46,70 & 315 & 300 & 125 & 98 & 82,05 & 9,50 & 68,95 & 19780 \\
\hline A & 5 & 36,04 & 355 & 320 & 135 & 135 & 53,17 & 12,60 & 70,24 & 20160 \\
\hline A & 6 & 39,22 & 330 & 235 & 110 & 140 & 74,66 & 11,90 & 65,97 & 20600 \\
\hline A & 7 & 44,50 & 255 & 245 & 115 & 125 & 36,90 & 12,70 & 78,74 & 20420 \\
\hline A & 8 & 42,34 & 275 & 375 & 90 & 90 & 29,29 & 14,20 & 53,87 & 17060 \\
\hline Ea & 1 & 46,90 & 275 & 180 & 82 & 85 & 41,56 & 14,50 & 44,14 & 17900 \\
\hline Ea & 2 & 33,27 & 215 & 230 & 70 & 86 & 32,39 & 10,45 & 51,20 & 14200 \\
\hline Ea & 3 & 29,08 & 320 & 245 & 100 & 105 & 46,37 & 11,42 & 64,80 & 19420 \\
\hline Ea & 4 & 36,39 & 305 & 215 & 76 & 79 & 56,77 & 9,75 & 73,33 & 16180 \\
\hline $\mathrm{Ea}$ & 5 & 38,73 & 260 & 190 & 80 & 90 & 27,63 & 12,30 & 67,48 & 15460 \\
\hline Ea & 6 & 39,94 & 320 & 303 & 100 & 125 & 39,50 & 13,50 & 72,96 & 21080 \\
\hline $\mathrm{Ea}$ & 7 & 42,77 & 240 & 330 & 130 & 105 & 43,54 & 14,60 & 69,52 & 17520 \\
\hline Ea & 8 & 57,68 & 280 & 205 & 100 & 95 & 30,00 & 14,40 & 63,89 & 17600 \\
\hline $\mathrm{Eb}$ & 1 & 45,44 & 445 & 280 & 100 & 94 & 54,91 & 14,40 & 60,07 & 18560 \\
\hline $\mathrm{Eb}$ & 2 & 31,28 & 315 & 215 & 72 & 91 & 47,14 & 10,92 & 57,69 & 15800 \\
\hline $\mathrm{Eb}$ & 3 & 33,65 & 280 & 215 & 87 & 94 & 38,72 & 12,40 & 55,65 & 17040 \\
\hline $\mathrm{Eb}$ & 4 & 23,00 & 260 & 225 & 100 & 87 & 44,01 & 11,90 & 49,16 & 15780 \\
\hline $\mathrm{Eb}$ & 5 & 25,00 & 265 & 270 & 90 & 85 & 30,00 & 11,60 & 70,26 & 16560 \\
\hline $\mathrm{Eb}$ & 6 & 52,26 & 325 & 200 & 90 & 100 & 38,40 & 12,50 & 71,20 & 16800 \\
\hline $\mathrm{Eb}$ & 7 & 35,43 & 290 & 240 & 100 & 95 & 32,48 & 9,35 & 95,19 & 16520 \\
\hline $\mathrm{Eb}$ & 8 & 48,31 & 220 & 215 & 90 & 90 & 28,02 & 12,90 & 81,40 & 15860 \\
\hline Ec & 1 & 39,23 & 345 & 260 & 88 & 128 & 43,34 & 10,10 & 84,16 & 17740 \\
\hline Ec & 2 & 39,96 & 380 & 260 & 97 & 117 & 56,19 & 13,10 & 55,73 & 21240 \\
\hline Ec & 3 & 43,54 & 285 & 255 & 96 & 110 & 37,66 & 13,60 & 67,65 & 20820 \\
\hline Ec & 4 & 51,95 & 345 & 260 & 119 & 118 & 42,45 & 13,80 & 53,62 & 20060 \\
\hline Ec & 5 & 35,58 & 275 & 185 & 90 & 95 & 45,50 & 9,90 & 87,88 & 17220 \\
\hline Ec & 6 & 53,64 & 330 & 260 & 100 & 110 & 42,58 & 12,40 & 85,48 & 18360 \\
\hline Ec & 7 & 40,30 & 245 & 250 & 105 & 110 & 40,19 & 14,70 & 65,65 & 19300 \\
\hline Ec & 8 & 42,08 & 345 & 240 & 90 & 95 & 26,81 & 13,65 & 72,16 & 16460 \\
\hline
\end{tabular}


APÊNDICE 11. Média da frequência de diarréia (porcentagem de dias com diarréia) por unidade experimental, de acordo com o bloco, no período de 1 a 14 e 1 a 35 dias de experimentação (Experimentos I e II)

\begin{tabular}{|c|c|c|c|}
\hline \multirow{2}{*}{ Bloco } & \multirow{2}{*}{ Tratamento $^{1}$} & \multicolumn{2}{|c|}{ Período } \\
\hline & & 1-14 dias & 1-35 dias \\
\hline \multirow{5}{*}{1} & $\mathrm{C}$ & 17,86 & 18,57 \\
\hline & $\mathrm{A}$ & 13,27 & 13,88 \\
\hline & $\mathrm{Ea}$ & 31,63 & 28,37 \\
\hline & $\mathrm{Eb}$ & 0,51 & 10,20 \\
\hline & Ec & 5,10 & 22,04 \\
\hline \multirow{5}{*}{2} & $\mathrm{C}$ & 10,71 & 28,57 \\
\hline & A & 21,43 & 10,00 \\
\hline & $\mathrm{Ea}$ & 36,73 & 41,84 \\
\hline & $\mathrm{Eb}$ & 11,73 & 10,41 \\
\hline & Ec & 1,02 & 14,69 \\
\hline \multirow{5}{*}{3} & $\mathrm{C}$ & 1,53 & 24,90 \\
\hline & A & 8,67 & 13,47 \\
\hline & $\mathrm{Ea}$ & 15,31 & 11,84 \\
\hline & $\mathrm{Eb}$ & 11,22 & 7,35 \\
\hline & Ec & 11,73 & 16,12 \\
\hline \multirow{5}{*}{4} & $\mathrm{C}$ & 23,98 & 41,02 \\
\hline & $\mathrm{A}$ & 9,18 & 9,39 \\
\hline & $\mathrm{Ea}$ & 26,02 & 18,98 \\
\hline & $\mathrm{Eb}$ & 4,08 & 14,49 \\
\hline & Ec & 16,84 & 11,02 \\
\hline \multirow{5}{*}{5} & $\mathrm{C}$ & 14,29 & 10,00 \\
\hline & A & 28,57 & 12,86 \\
\hline & $\mathrm{Ea}$ & 17,86 & 21,43 \\
\hline & $\mathrm{Eb}$ & 0,00 & 2,86 \\
\hline & Ec & 21,43 & 27,14 \\
\hline \multirow{5}{*}{6} & $\mathrm{C}$ & 25,00 & 34,29 \\
\hline & $\mathrm{A}$ & 35,71 & 20,00 \\
\hline & $\mathrm{Ea}$ & 17,86 & 10,00 \\
\hline & $\mathrm{Eb}$ & 17,86 & 12,86 \\
\hline & Ec & 28,57 & 14,29 \\
\hline \multirow{5}{*}{7} & $\mathrm{C}$ & 28,57 & 22,86 \\
\hline & A & 0,00 & 8,57 \\
\hline & $\mathrm{Ea}$ & 14,29 & 5,71 \\
\hline & $\mathrm{Eb}$ & 21,43 & 8,57 \\
\hline & Ec & 32,14 & 17,14 \\
\hline \multirow{5}{*}{8} & $\mathrm{C}$ & 50,00 & 45,71 \\
\hline & $\mathrm{A}$ & 17,86 & 10,00 \\
\hline & $\mathrm{Ea}$ & 0,00 & 11,43 \\
\hline & $\mathrm{Eb}$ & 25,00 & 11,43 \\
\hline & Ec & 3,57 & 1,43 \\
\hline
\end{tabular}


APÊNDICE 12. Média da frequência de diarréia (porcentagem de dias com diarréia) por unidade experimental, de acordo com o bloco, no período de 1 a 14 e 1 a 35 dias de experimentação (Experimento III)

\begin{tabular}{|c|c|c|c|}
\hline \multirow{2}{*}{ Bloco } & \multirow{2}{*}{ Tratamento $^{1}$} & \multicolumn{2}{|c|}{ Período } \\
\hline & & 1-14 dias & $1-35$ dias \\
\hline \multirow{5}{*}{9} & C & 39,29 & 47,14 \\
\hline & A & 14,29 & 8,57 \\
\hline & Ea & 10,71 & 21,43 \\
\hline & $\mathrm{Eb}$ & 32,14 & 31,43 \\
\hline & Ec & 21,43 & 10,00 \\
\hline \multirow{5}{*}{10} & C & 21,43 & 25,71 \\
\hline & A & 10,71 & 5,71 \\
\hline & $\mathrm{Ea}$ & 21,43 & 40,00 \\
\hline & Eb & 3,57 & 1,43 \\
\hline & Ec & 14,29 & 18,57 \\
\hline \multirow{5}{*}{11} & C & 32,14 & 15,71 \\
\hline & A & 14,29 & 17,14 \\
\hline & $\mathrm{Ea}$ & 32,14 & 27,14 \\
\hline & Eb & 32,14 & 60,00 \\
\hline & Ec & 46,43 & 50,00 \\
\hline \multirow{5}{*}{12} & C & 17,86 & 25,24 \\
\hline & A & 17,86 & 30,00 \\
\hline & $\mathrm{Ea}$ & 7,14 & 30,00 \\
\hline & Eb & 10,71 & 38,57 \\
\hline & Ec & 25,00 & 30,00 \\
\hline
\end{tabular}

